
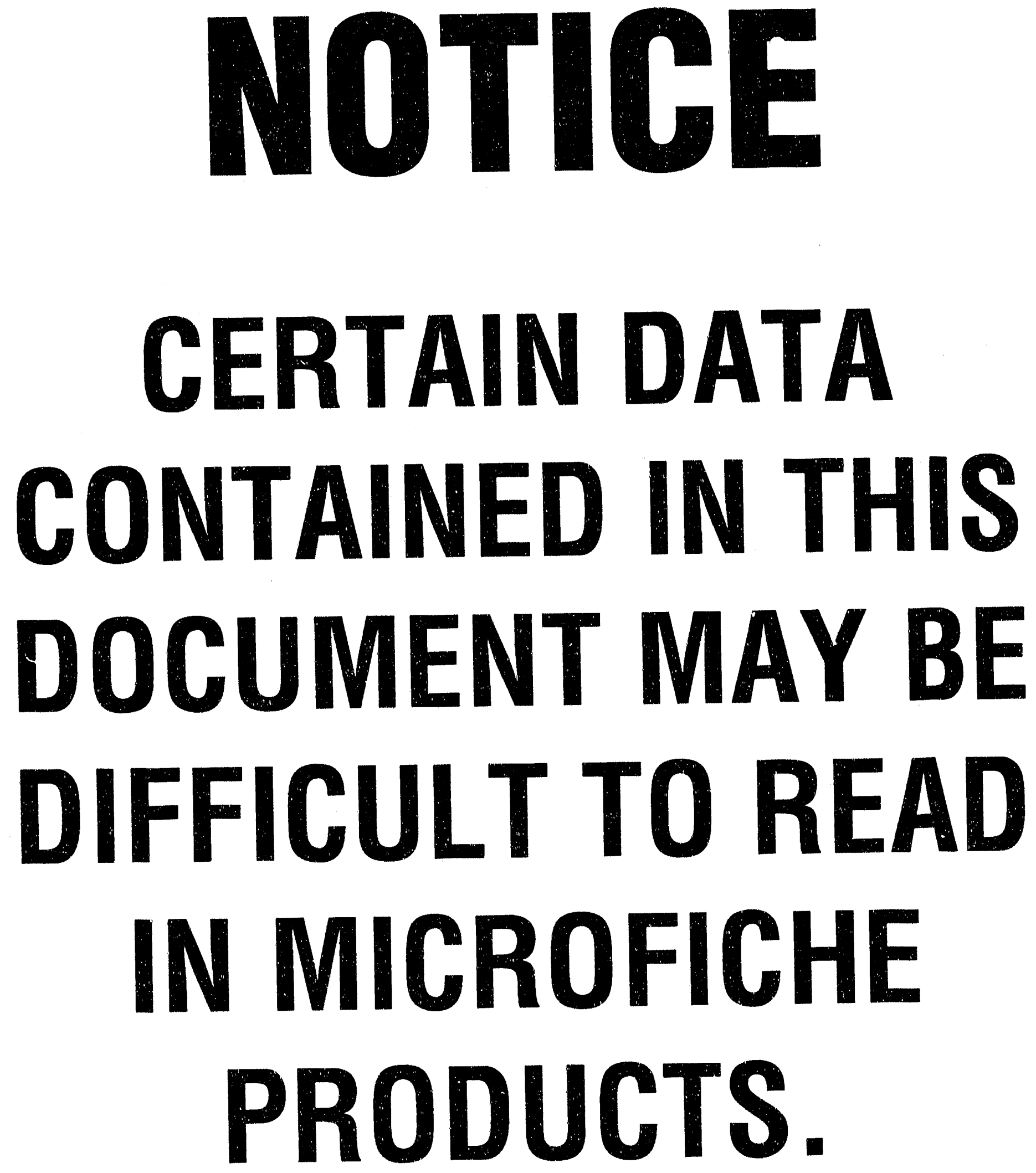


\section{TIME-SERIES ANALYSIS OF ION AND ISOTOPE GEOCHEMISTRY OF SELECTED SPRINGS OF THE NEVADA TEST SITE, NYE COUNTY, NEVADA}

by

Brad F. Lyles

John Edkins

Roger L. Jacobson

John W. Hess

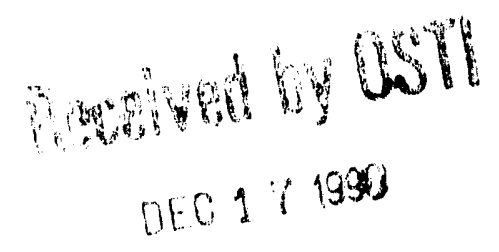

November 1990 
This report was prepared as an account of work sponsored by the United States Government. Neither the United States nor the United States Department of Energy, nor any of their employees, makes any warranty, express or implied, or assumes any legal liability or responsibility for the accuracy, completeness or usefulness of any information, apparatus, product or process disclosed. or represents that its use would not infringe privately owned rights. Reference herein to any specific commercial project, process, or service by trade name. mark, manufacturer, or otherwise. does not necessarily constitute or imply its endorsement, recommendation, or favoring by the United States Givernment or any agency thereof. The views and opinions of authors expressed herein do not necessarily state or reflect those of the United States Government or any agency thereof.

This report has been reproduced directly from the best available copy.

Available from:

National Technical Information Service

NTIS Energy Distribution Center

P.O. Box 1300

Oak Ridge. TN 37831

Price Cude:

Printed Copy A06

Microfiche A(01 


\title{
TIME-SERIES ANALYSIS OF ION AND ISOTOPE GEOCHEMISTRY OF SELECTED SPRINGS OF THE NEVADA TEST SITE, NYE COUNTY, NEVADA
}

\author{
by \\ Brad F. Lyles ${ }^{1}$ \\ John Edkins ${ }^{2}$ \\ Roger L. Jacobson ${ }^{3}$ \\ John W. Hess ${ }^{4}$ \\ Water Resources Center \\ Desert Research Institute \\ University of Nevada System
}

Publication $\# 45068$

prepared for

Nevada Operations Office

U.S. Department of Energy

Las Vegas, Nevada

November 1990

${ }^{1}$ Assistant Hydrogeologist, Water Resources Center, Desert Research Institute, L'niversity of Nevada System

${ }^{2}$ Former Research Associate, Water Resources Center, Desert Research Institute

${ }^{3}$ Associate Research Professor, Water Resources Center, Desert Research Institute, University of Nevada System

${ }^{4}$ Executive Director, Water Resources Center, Desert Research Institute, University of Nevada System 


\section{ACKNOWLEDGMENTS}

This work was funded by the U.S. Department of Energy, Nevada Operations Office (Contracts DE-AC08-81NV10162 and DE-AC08-85NV10384). The authors sincerely thank the diligence and relentless effort of the field support personnel who collected the bulk of data for this study, including: Bert Elliot, Kevin Sullivan, Tom Morris, Bruce Wert, Nancy Matuska, Sam Hokett, Lee Huckins, Wyn Ross, and Alan McKay. Further thanks are extended to Todd Mihevc for his micrologger expertise, to Barbara Nauroth and Deborah Wilson for their Electronic Publishing skills, and last, but not least, to the following reviewers: Karla Cosens, Marjory Jones, Dr. Britt Jacobson, and Dr. Neil Ingraham. 


\begin{abstract}
The temporal variations of ion and isotope geochemistry were observed at six selected springs on the Nevada Test Site, Nye County, Nevada and included: Cane, Whiterock, Captain Jack, Topopah, Tippipah, and Oak Springs. The sites were monitored from 1980 to 1982 and the following parameters were measured: temperature, $\mathrm{pH}$, electrical conductance, discharge, cations $\left(\mathrm{Ca}^{2+}, \mathrm{Mg}^{2+}, \mathrm{Na}^{+}, \mathrm{K}^{+}\right)$, anions $\left(\mathrm{Cl}^{-}\right.$, $\left.\mathrm{SO}_{4}^{2-}, \mathrm{HCO}_{3}^{-}\right)$, silica, stable isotopes $\left(\delta^{18} \mathrm{O}, \delta \mathrm{D}, \delta^{13} \mathrm{C}\right)$, and radioactive isotopes $\left({ }^{3} \mathrm{H}\right.$, ${ }^{14} \mathrm{C}$ ). A more detailed study was continued from 1982 to 1988 at Cane and Whiterock Springs. Field microloggers were installed at these sites in 1985 to measure the high frequency response of temperature, electrical conductance, and discharge to local precipitation.
\end{abstract}

Cane and Whiterock Springs respond rapidly to extreme precipitation events. Discharge response lag-time is a function of precipitation intensity and duration, as well as unsaturated and saturated zone hydrodynamics. Approximately twice as much precipitation, over a unit storm period, fell at Cane Spring as at Whiterock Spring; however, Whiterock responded nearly five times faster than Cane, suggesting better communication through the unsaturated zone at Whiterock than at Cane.

Stage fluctuations near the discharge point dissolve minerals/salts as groundwater inundates the mineralized zone immediately above the equilibrium water table. This phenomena was most noticeable at Whiterock Spring and lagged the discharge response by several hours.

Stable isotope analysis of precipitation and groundwater suggests a 1.5 to 2 month travel time for meteoric water to migrate from the recharge area to the discharge point. Groundwater age determinations suggest a mean age of approximately 30 years at Whiterock Spring and possibly older at Cane Spring. However, the short travel time and geochemical integrity of recharge pulses suggest that the waters are poorly mixed along the flow paths. 


\section{CONTENTS}

ACKNOWLEDGMENTS

ABSTRACT

INTRODUCTION

Purpose of Investigation

Methodology and Procedures

CANE SPRING $\quad 8$

Setting $\quad 8$

Geochemistry $\quad 8$

Time Series $\quad 11$

Precipitation $\quad 11$

Discharge $\quad 12$

Ions $\quad 14$

Isotopes 16

Micrologger Statistics $\quad 20$

Surnmary $\quad 25$

$\begin{array}{ll}\text { WHITEROCK SPRING } & 27\end{array}$

$\begin{array}{ll}\text { Setting } & 27\end{array}$

$\begin{array}{ll}\text { Geochemistry } & 27\end{array}$

Time Series $\quad 30$

Frecipitation $\quad 30$

Discharge $\quad 30$

Ions

Isotopes 36

Micrologger Statistics $\quad$ is

Summary 4.45

CAPTAIN JACK SPRING +9

Setting 49

Geochemistry $\quad 49$

Time Series +19

TOPOPAH SPRING

Setting $\quad \leq 2$

Geochemistry $\quad$ 政

Time Series 
TIPPIPAH SPRING

Setting

Geochemistry

Time Series

OAK SPRING

Setting 58

Geochemistry $\quad 58$

Time Series $\quad 60$

$\begin{array}{ll}\text { DISCUSSION } & 61\end{array}$

CONCLUSIONS

$\begin{array}{ll}\text { REFERENCES } & 71\end{array}$

APPENDICES

A. Calibration of 11.25 Degree V-Notch Weir 73

B. Time-Series Discharge Measurements from Selected $\begin{array}{ll}\text { Springs on the NTS } & 79\end{array}$

C. Time-Series Chemistry from Selected Springs on the NTS

D. Time-Series Isotope Data from Selected Springs on the NTS 9.4

E. Computer Output Pesults from SNORM 102

F. Monthly Summary Statistics of Micrologger Data from Cane and Whiterock Springs 


\section{FIGURES}

1. Location Map of Sampled Springs on the NTS.

2. Example Flow Record from Stevens Chart Records (May 4, 1981 to June 5, 1981) - a) Cane Spring and b) Whiterock Spring.

3. Location Map of Cane Spring.

4. Cane Spring - Time versus Precipitation, Discharge, $\delta \mathrm{D}$, $\delta^{18} \mathrm{O}$, and $\delta^{13} \mathrm{C}$ from April 1981 to February 1988.

5. Cane Spring - Time versus Water Temperature, Calcium, Magnesium, Sodium, Potassium, Chloride, Sulfate, $\mathrm{SiO}_{2}$, and Nitrate.

6. Cane Spring - Time versus $\delta^{18} \mathrm{O}$ from Cane Spring and Precipitation Monitoring Station ST4.

7. Cane Spring $-\delta D$ versus $\delta^{18} \mathrm{O}$ from October 1981 to December 1986.

8. Cane Spring - Micrologger Daily Averages from November 1985 to August 1987.

9. Cane Spring - Micrologger Data from May 1987.

10. Cane Spring - Micrologger Data from May 14 to May 22, 1987.

11. Location Map of Whiterock Spring.

12a. Whiterock Spring West - Time versus Precipitation, Discharge, $\delta \mathrm{D}, \delta^{18} \mathrm{O}$, and $\delta^{13} \mathrm{C}$ from March 1981 to February 1988.

12b. Whiterock Spring East - Time versus Precipitation, Discharge, $\delta \mathrm{D}, \delta^{18} \mathrm{O}$, and $\delta^{13} \mathrm{C}$ from March 1981 to February 1988.

13a. Whiterock Spring West - Time versus Temperature, Calcium, Magnesium, Sodium, Potassium, Chloride. Sulfate. Bicarbonate. $\mathrm{SiO}_{2}$, and Nitrate. 
13b. Whiterock Spring East - Time versus Temperature, Calcium, Magnesium, Sodium, Potassium, Chloride, Sulfate, Bicarbonate, $\mathrm{SiO}_{2}$, and Nitrate.

14. Whiterock Spring $-\delta D$ versus $\delta^{18} \mathrm{O}$ from October 1981 to December 1986.

15. Tritium Distribution for Southern Nevada Precipitation from 1953 to 1983.

16. Whiterock Spring - Micrologger Daily Averages from December 1985 to January 1988.

17. Whiterock Spring - Micrologger Data from May 1987.

18. Whiterock Spring - Micrologger Data from May 12 to May 20, 1987.

19. Whiterock Spring - Micrologger Data from July 1987.

20. Whiterock Spring - Micrologger Data from July 20 to July 28, 1987.

21. Durov Diagram Showing Chemical Variations Between Selected Springs on the NTS.

22. Winter and Summer Precipitation - Cane versus Area 12 Mesa.

23a. $\delta \mathrm{D}$ versus $\delta^{18} \mathrm{O}$ for Selected Springs on the NTS.

23b. Cane and Whiterock Springs - $\delta \mathrm{D}$ versus $\delta^{18} \mathrm{O}$.

24. Cane and Whiterock Springs - Time versus Precipitation. Discharge, and $\delta^{18} \mathrm{O}$.

25. Cane and Whiterock Springs - Mircrologger Data

Comparison from May 12 to May 22, 1987. 


\section{TABLES}

1. Location of Selected Springs on the NTS. 1

2. Equipment List for Data-Logger Installations. 5

3. Cane Spring Ion Chemistry Summary Statistics from January 1981 to January 1986.

4. Summary of Results from WATEQDR for Mean Cane Spring Chemistry.

5. Summary of Precipitation Data from NWS Cane Spring Meteorological Station $(\mathrm{cm})$.

6. Cane Spring Discharge Summary Statistics from April 1981 to February 1988.

7. Cane Spring Isotope Chemistry Summary Statistics from March 1981 to December 1986.

8. Summary of Precipitation at Cane Spring May 1987.

9. Whiterock Spring Ion Chemistry Summary Statistics from January 1981 to April 1985.

10. Summary of Results from WATEQDR for Mean

Whiterock Spring Chemistry.

11. Summary of Precipitation Data from Area 12 Mesa

Meteorological Station $(\mathrm{cm})$.

12. Whiterock Spring Discharge Summary Statistics from March 1981 to February 1988.

13a. Whiterock Spring 'West Isotope, Chemistry Summary Statistics from March 1981 to December 1986.

13b. Whiterock Spring East Isntope Chemistry Summary

Statistics from March 1981 to December 1986.

14. Summary of Precipitation at Whiterock Spring May 1987. 
15. Summary of Precipitation at Whiterock Spring July 1987.

16. Captain Jack Ion Chemistry Summary Statistics from March 1981 to June 1982.

17. Summary of Results from WATEQDR for Mean Caplain Jack Chemistry.

18. Topopah Spring Ion Chemistry Summary Statistics from March 1981 to June 1982.

19. Summary of Results from WATEQDR for Mean Topopah Spring Chemistry.

20. Tippipah Spring Ion Chemistry Summary Statistics from July 1980 to April 1982.

21. Summary of Results from WATEQDR for Mean Tippipah Spring Chemistry.

22. Oak Spring Ion Chemistry Summary Statistics from January 1981 to April 1982.

23. Summary of Results from WATEQDR for Mean Oak Spring Chemistry.

24. Spring Discharge Characteristics for Selected Springs on the NTS.

25. Estimated Minimum Precipitation Threshold Needed to Produce Spring Discharge Response at Cane and Whiterock Springs. 


\section{INTRODUCTION}

Various aspects of the genlogy, hydrology, and hydrochemistry of the Nevada Test Size (NTS) and vicinity have been described in the literature (Claassen, 1973; Winograd and Thordarson, 1975; Winograd and Thordarson, 1968). Detailed temporal hydrochemical studies have been conducted in carbonate rock provinces by Jacobson (1973), Sara (1977), and Larson et al. (1986) to name a few, and in geothermal springs by Lyles (1985). However, little or no information is available on the temporal variations of springs on the NTS. This study was initiated in 1980 to further understanding of the temporal variations in selected springs of the NTS, based on seasonal meteuric input signals. Six springs were observed from 1980 to 1982, with two of these springs being studied from 1980 to 1987 (Cane and Whiterock Springs). Cane and Whiterock Springs will be described in detail based on ionic and isotopic variations. The spring locations are listed in Table 1 and presented in Figure 1. Time-series analysis of physical and chemical data will be used to better understand groundwater flow characteristics near these discharge points.

\section{PURPOSE OF INVESTIGATION}

Groundwater recharge in arid regions is poorly understood. Attempts are currently underway to develop reliable techniques that can be used to measure net recharge. However, several years prior to the onset of this study it was noted that groundwater discharge from springs on the NJTS varied greatly during precipitation events and, therefore, supported the theory that recharge to these springs was derived from areas in the immediate vicinity of the discharge points (Winograd and Thordarson, 1975). Therefore, it is hypothesized that measurements of the input (precipitation) and output (discharge) signals will give some estimates of the minimum precipitation threshold needed to initiate flow responses (i.e., recharge). Additionally, the

TABLE 1. LOCATION OF SELECTED SPRINGS ON THE NTS.

\begin{tabular}{lcccc}
\hline & \multicolumn{2}{c}{ Location } & \multicolumn{2}{c}{ Elevation } \\
Spring Name & (DMS) & (DMS) & Feet & Meters \\
\hline Cane & 1160542 & 364757 & 4060 & 1237 \\
Whiterock & 1160754 & 371205 & 5025 & 1532 \\
Captain Jack & 1161007 & 371006 & 5765 & 1757 \\
Topopah & 1161615 & 365617 & 5700 & 1737 \\
Tippipah & 1161212 & 370235 & 5200 & 1585 \\
Oak & 1160430 & 371445 & 5860 & 1730 \\
\hline
\end{tabular}




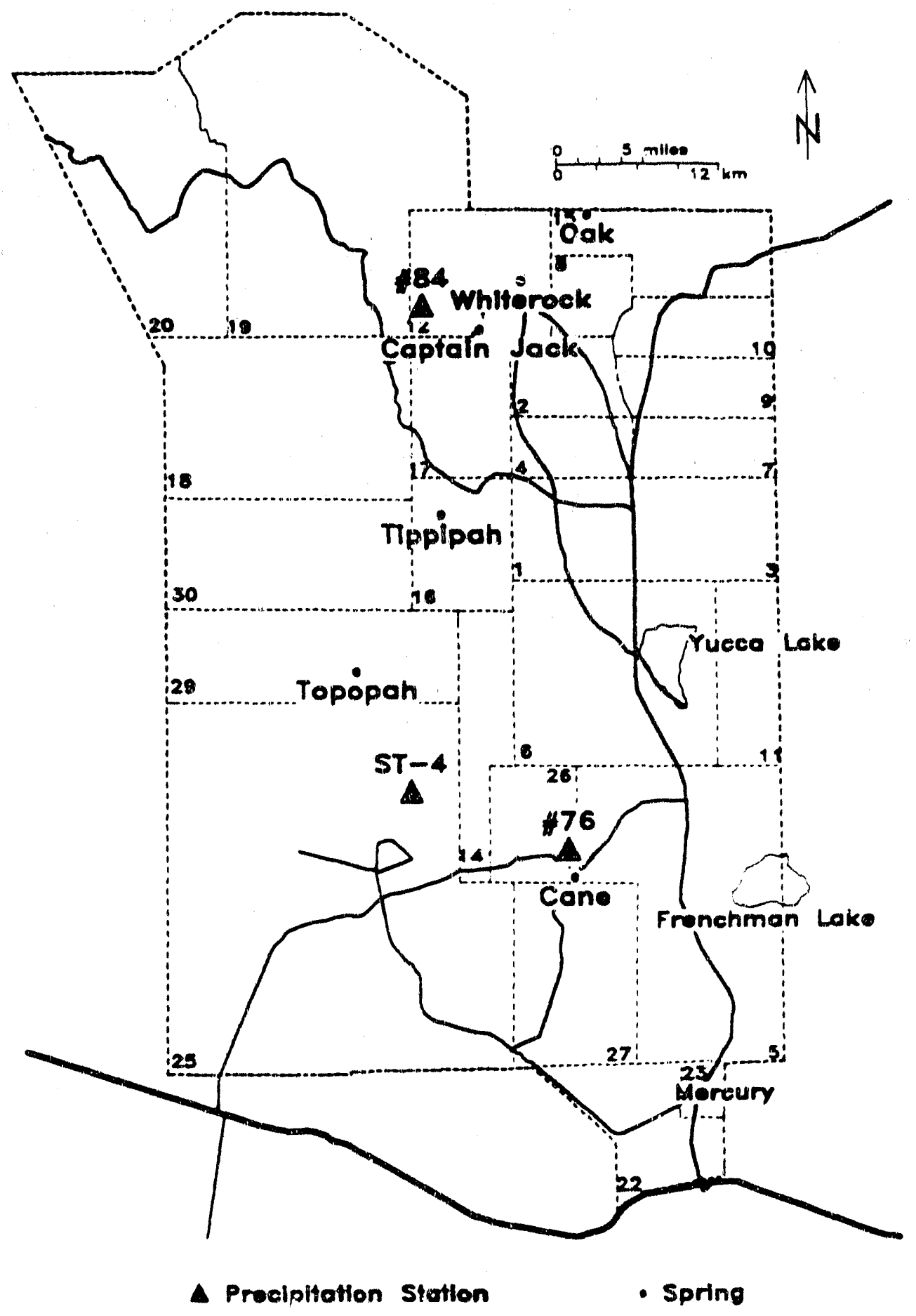

FIGURE 1. Location Map of Sampled Springs on the NTS. 
flow response time to precipitation events will give an indication of the proximity of the recharge area to the spring discharge point. This response time is a measurement of the recharge waters moving through the unsaturated zone. Environmental isotopes will be used $t$, track specific pulses of recharge water from precipitation through the aquifer to the discharge point, thereby dating the travel time of recharge.

It is further hypothesized that groundwaters attain most of their dissolved solids in the soil zone and are relatively unchanged once they reach the fractured rock aquifer. Time-series measurements of ions and electrical conductance will be made to further understand the behavior of dissolved solids at these springs.

The final purpose of this study is to test remote data acquisition systems. Remote data loggers ivere installed to accurately measure physical parameters at Cane and Whiterock Springs to refine the sample frequency and determine if high frequency data acquisition is valuable in spring response studies.

\section{METHODOLOGY AND PROCEDURES}

During the course of $t$. $s$ study, six springs were monitored. A variety of physical and chemical parameters were observed, such as: $\mathrm{pH}$, electrical conductivity, temperature, discharge, cations, anions, and isotopes. Field measurements of $\mathrm{pH}$ were conducted at the beginning of this study. Measurements were made with Corning and Orion Digital pH Meters, using a two buffer calibration technique The buffers were allowed to equilibrate to spring temperature prior to calibration.

Electrical conductivity (EC) was measured using a YSI EC Meter. The meter was calibrated at the beginning and end of each sampling trip. The field data were recorded in raw form and were later corrected for calibration variance and temperature effects.

Spring discharge measurements were obtained by timing the filling of a volumetric flask (witt the exception of Tippipah Spring where relative measures of stage in an adit were observed). Cane and Whiterock Springs were outfitted with V-notch weirs. Due to the low discharge range of these springs $(0.01$ to $0.1 / / \mathrm{sec})$, it was necessary to develop an $11.25^{\circ} \mathrm{V}$-notch weir. Calibration and design information is listed in Appendix A. Stage at the $V$-notch weirs was monitored with Steven type-F chart recorders. This instrumentation was found to be an ineffective means of data collection; several data gaps were attributed to site disruption due to wind and animals, and possibly from ground motion due to testing. The measurement resolution was also found to be inadequate for the needs of this study. Exmmples of stage records for Cane and Whiterock Springs are shown in Figures $2 a$ and $2 b$, respectively. Several irregularities can be observed in these figures. 


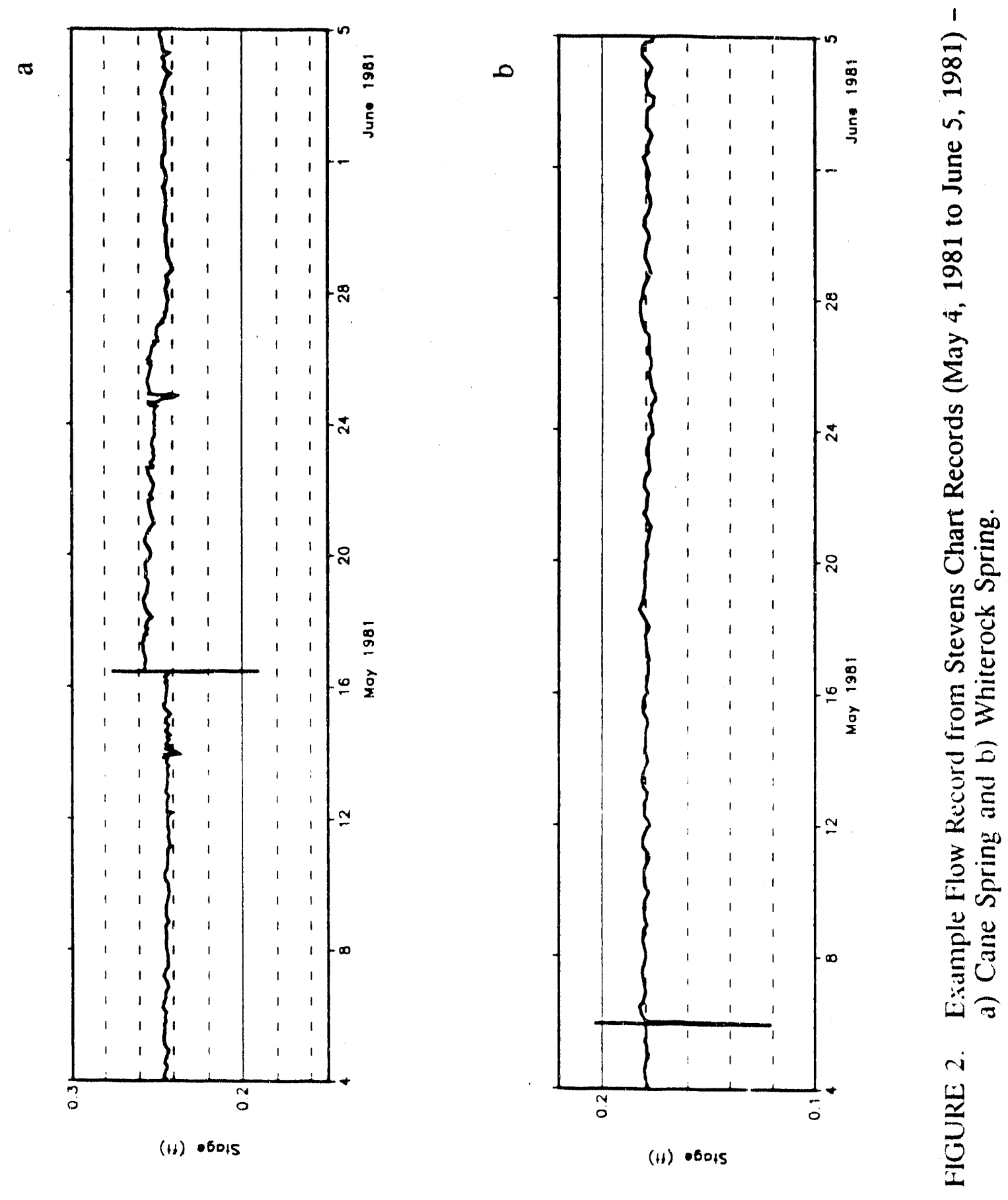


During the latter portion of this study, field microloggers were installed at Cane and Whiterock Springs. A variety of field parameters were monitored, including spring discharge, water temperature, water EC, air temperature, barometric pressure, and precipitation. The data were collected with Campbell Scientific $21 \mathrm{X}$ Microloggers and were remotely down-loaded to a SUN 3/280 main frame computer via telephone modern. Details of the equipment used are listed in Table 2.

All springs were periodically sampled for gross chemistry, temperature, conductivity, and $\mathrm{pH}$; flow measurements were taken at the time of sampling. Water samples were stored in coolers and refrigerated within eight hours of sampling time. Water samples were routinely analyzed for $\mathrm{Ca}^{2+}, \mathrm{Mg}^{2+}, \mathrm{Na}^{+}, \mathrm{K}^{+}, \mathrm{HCO}_{3}^{-}, \mathrm{Cl}^{-}, \mathrm{SO}_{4}^{2-}$, $\mathrm{NO}_{3}^{-}$, and $\mathrm{SiO}_{2}$ using standard atomic absorption, selective ion electrode, and wet chemical techniques by the Desert Research Institute, Water Resources Center laboratory staff. Field $\mathrm{pH}$ measurements were eventually discontinued because measurements under laboratory conditions proved to be in close agreement $(+0.05)$ with those taken in the field under ideal conditions (meter calibration with two buffers equilibrated to sample temperature in fair weather).

Geochemical parameters were computed with the computer program WATEQDR (Bohm and Jacobson, 1981). The partial pressure of $\mathrm{CO}_{2}\left(\mathrm{PcO}_{2}\right)$ was computed as a function of temperature, ionic strength, $\mathrm{pH}$, and bicarbonate concentration:

$$
\begin{aligned}
a \mathrm{H}_{2} \mathrm{CO}_{3} & =\text { activity } \mathrm{H}_{2} \mathrm{CO}_{3} \\
\mathrm{PCO}_{2} & =a \mathrm{H}_{2} \mathrm{CO}_{3} / \mathrm{KCO}_{2}
\end{aligned}
$$

Measurements of $\mathrm{PCO}_{2}$ are useful for determining signatures of differing hydrologic regimes. The computed values of $\mathrm{PCO}_{2}$ are reported as $\log -\mathrm{PCO}_{2} ;$ a log- $-\mathrm{PCO}_{2}$

\section{TABLE 2. EQUIPMENT LIST FOR DATA-LOGGER INSTALLATIONS.}

\begin{tabular}{lll}
\hline Manufacturer & \multicolumn{1}{c}{ Item } & \multicolumn{1}{c}{ Model } \\
\hline Campbell Scientific Inc. & $\begin{array}{l}\text { Micrologger } \\
\text { Thermistor }\end{array}$ & $21 \mathrm{X}$ \\
Druck Inc. & Pressure Transducer & 107 \\
Y'SI & PDCR 830, 1 PSIG \\
& Barometer & $2014 \mathrm{WH}$ \\
Sierra/Misco Inc. & EC Cell & 3300 \\
\hline
\end{tabular}


value of -3.5 is at equilibrium with the atmosphere. The solubility products for calcite and dolomite are computed with the following equations:

$$
\begin{aligned}
\text { calcite }-\mathrm{K}_{\mathrm{cal}} & =\mathrm{aCa}^{2+} \frac{\mathrm{K}_{2} \mathrm{a}^{2} \mathrm{HCO}_{3}^{-}}{\mathrm{K}_{1} \mathrm{aH}_{2} \mathrm{CO}_{3}} \\
\text { dolomite }-\mathrm{K}_{\mathrm{dol}} & =\mathrm{aCa}^{2+}+\mathrm{aMg}^{2+}+\mathrm{a}^{2} \mathrm{CO}_{3}^{2-}
\end{aligned}
$$

where $\mathrm{K}_{1}$ and $\mathrm{K}_{2}$ are carbonate equilibrium constants and "a" is the activity of the solute (Drever, 1982). The activity of ionic species are approximated with the Debye-Huckel equation; the product of the activities are used to calculate the ion activity product (IAP). The saturation index (SI) is calculated with the following equation:

$$
\mathrm{SI}=\log \frac{\mathrm{IAP}}{\mathrm{K}_{\min }}
$$

where $\mathrm{K}_{\min }$ is $\mathrm{K}_{\text {cal }}$ for $\mathrm{SI}_{\text {cal }}$ and is $\mathrm{K}_{\text {dol }}$ for $\mathrm{SI}_{\text {dol }}$. Saturation values below 0.0 are undersaturated and values above 0.0 are supersaturated; however, there is a zone of quasiequilibrium $0.0+/-0.2$.

The geochemical program SNORM (Bodine and Jones, 1986) was used to approximate the normative salts that may have contributed to the bulk spring chemical composition. These salts are the quantitative ideal equilibrium assemblage that would crystallize if the water evaporated to dryness at $25^{\circ} \mathrm{C}$ and 1 bar pressure under atmospheric partial pressure of $\mathrm{CO}_{2}$. The program was applied to spring waters to estimate minerals that may have dissolved during high discharge events. The model results were used as a qualitative approach.

To obtain estimates of groundwater age and potential recharge sources, a variety of environmental isotopes were analyzed: tritium samples were collected in 1 liter glass sample bottles for analysis at the DRI-Reno Enriched Tritium Laboratcry; oxygen/deuterium samples were collected in $125 \mathrm{ml}$ glass vials for analysis at the DRILas Vegas Environmental Isotope Laboratory; a ${ }^{14} \mathrm{C}$ sample was collected from Cane Spring and was analyzed by Teledyne Isotopes, Inc., New Jersey. The carbon sample was collected in a nitrogen purged 100 liter carboy. The sample was laboratory-precipitated within 48 hours of sample collection with Strontium Chloride and Sodium Hydroxide; the precipitant was concentrated and dried before shipment to Teledyne.

The results of stable isotope analysis, expressed in $\delta$ (delta) notation, are computed as a per mil difference from a standard by: 


$$
\begin{aligned}
\delta D^{\circ} \% & =\left(\frac{\left({ }^{2} \mathrm{H} /{ }^{1} \mathrm{H}\right)_{\text {sample }}-\left({ }^{2} \mathrm{H} /{ }^{1} \mathrm{H}\right)_{\text {SMOW }}}{\left({ }^{2} \mathrm{H} /{ }^{1} \mathrm{H}\right)_{\text {SMOW }}}\right) \times 10^{3} \\
\delta^{18} \mathrm{O}^{\circ} \% & =\left(\frac{\left({ }^{18} \mathrm{O} /{ }^{16} \mathrm{O}\right)_{\text {sample }}-\left({ }^{18} \mathrm{O} /{ }^{16} \mathrm{O}\right)_{\text {SMOW }}}{\left({ }^{18} \mathrm{O} /{ }^{16} \mathrm{O}\right)_{\text {SMOW }}}\right) \times 10^{3} \\
\delta^{13} \mathrm{C} \% & =\left(\frac{\left({ }^{13} \mathrm{C} /{ }^{12} \mathrm{C}\right)_{\text {sample }}-\left({ }^{3} \mathrm{C} /{ }^{12} \mathrm{C}\right)_{\mathrm{PDB}}}{\left({ }^{13} \mathrm{C} /{ }^{12} \mathrm{C}\right)_{\mathrm{PDB}}}\right) \times 10^{3}
\end{aligned}
$$

\section{SMOW $=$ Standard Mean Ocean Water \\ $\mathrm{PDB}=$ PeDee Formation Belemnites}

Fundamental statistics were used to interpret the temporal data collected from each spring, including: minimum, maximum, mean, standard deviation (SDEV), sum, and coefficient of variation (Coef. Var.). The coefficient of variation is simply the deviation about the mean, normalized by the mean, expressed as a percent:

$$
\text { Coef } \operatorname{Var}(\%)=\frac{\text { SDEV }}{\text { mean }} * 100
$$

This statistic is used to compare the variation of a parameter against the error associated with the measurement of that parameter.

Cross correlation was used to measure the lagged linear correlation between two equally spaced temporal variables (Davis, 1973, pp. 232-236). The variables are lagged past each other in a step-wise fashion. At each lag position, the linear correlation was computed $\left(\mathrm{R}^{2}\right)$. 


\section{CANE SPRING}

\section{SETTING}

Cane Spring is located at $36^{\circ} 47^{\prime} 57^{\prime \prime} \mathrm{N}$. latitude, $116^{\circ} 05^{\prime} 42^{\prime \prime} \mathrm{W}$. longitude at an elevation of $1,237 \mathrm{~m}(4,060 \mathrm{ft})$ on the northeast-trending Cane Spring Fault Zone. The spring lies low on a hillside about $0.9 \mathrm{~km}$ south from a southward bend in Cane Spring Road at a point roughly $10 \mathrm{~km}$ west of its juncture with Mercury Highway (Figure 3).

Soils in the area are poorly developed in alluvial materials, which were derived from the surrounding hills composed of Miocene-aged volcanics of the Wahmonie and Salyer formations (Poole et al., 1965). The Wahmonie in the vicinity of the spring is primarily composed of dacite and rhyodacite lava flows containing quartz, plagioclase feldspars, pyroxene, horneblende, biotite, and magnetite. The Salyer formation near the spring is composed of lithic breccias, breccia flows, tuffs and tuff breccias, and sandstones of similar mineralogy. The bedrock in the area is highly fractured and faulted, with numerous, smaller faults terminating in the Cane Spring Fault Zone.

Water discharging from the spring collects in an adit which was hand dug roughly $15 \mathrm{~m}$ southward into the hillside. The water currently discharges through a gravity-feed pipe under a small earthen dam at the mouth of the adit. However, large phreatophytes and wet soils (within $50 \mathrm{~m}$ of the adit) indicate local groundwater discharge is not restricted to the adit pool.

\section{GEOCHEMISTRY}

Cane Spring waters are dominantly sodium-calcium-bicarbonate-type waters. The mean equivalent concentrations of sodium and calcium ions over the sampling period were more than twice that of magnesium, the next most-concentrated cation. Bicarbonate ion was at least five times more concentrated than either sulfate or chloride. The mean and standard deviation for dissolved constituents in the 29 samples are given in Table 3. The mean chemical composition of this water was run through the computer program WATEQDR to estimate geochemical characteristics of the spring. A summary of the results from this program are listed in Table 4.

The mean spring chemistry has a $\mathrm{PCO}_{2}$ level nearly one order of magnitude above atmospheric. The dominate sulfate minerals are nearly 2.5 times undersaturated and the major carbonate minerals are near equilibrium, but are also undersaturated.

According to Garrels and Mackenzie (1967), dissolution of felsic volcanics should result in waters high in bicarbonate, sodium, and calcium. The bicarbonate 


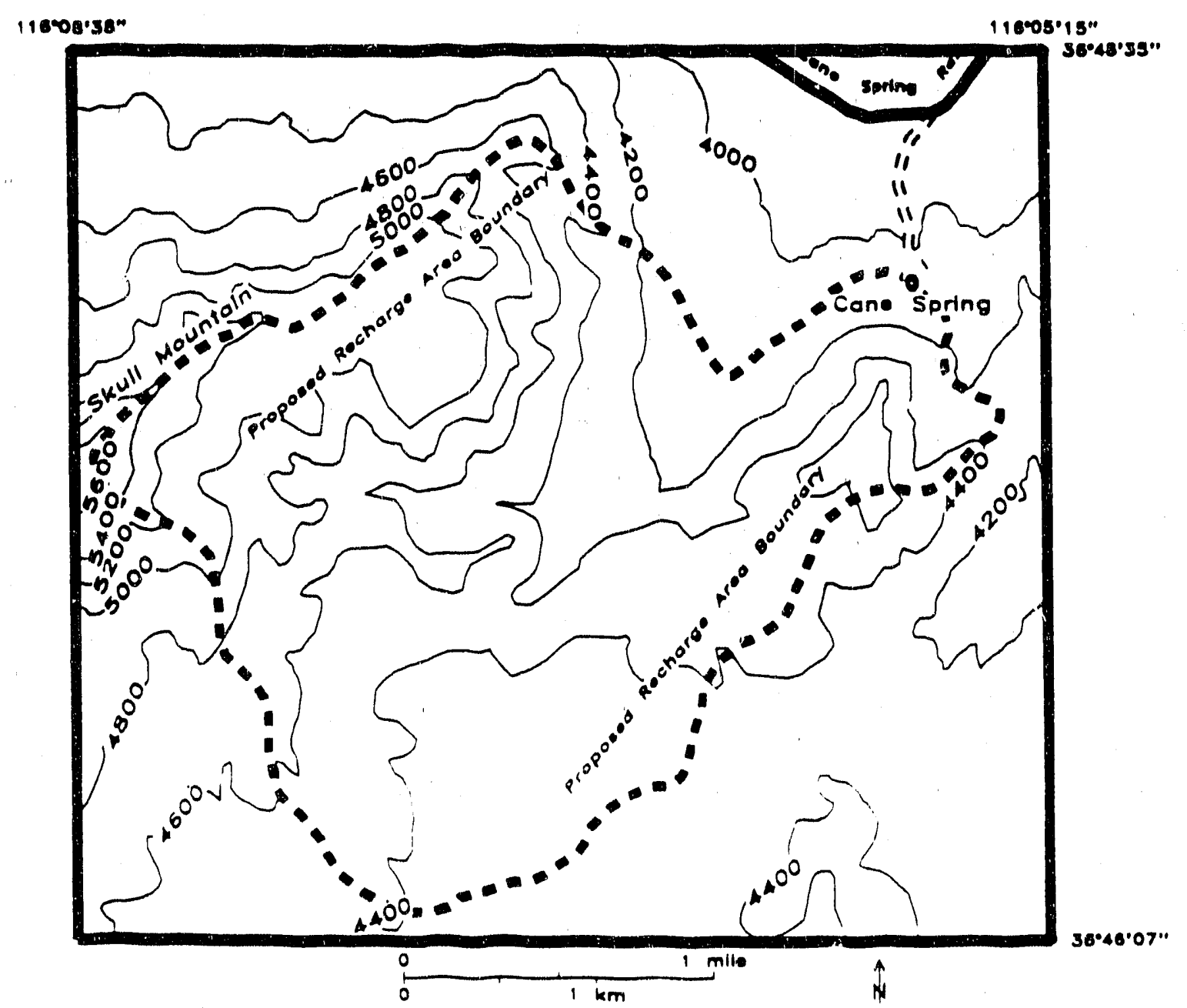

FIGURE 3. Location Map of Cane Spring. Elevation Contours (feet), Pared Roads (solid), Dirt Roads (open-dashed), and Recharge Boundary (dashed) are Shown. 
TABLE 3. CANE SPRING ION CHEMISTRY SUMMARY STATISTICS FROM JANUARY 1981 TO JANUARY 1986.

\begin{tabular}{lccccccc}
\hline Variable & Min. & Max. & Mean & SDEV & Coef. Var. ${ }^{* *}$ & $\mathrm{n}^{* * *}$ \\
\hline Temp. $\left({ }^{\circ} \mathrm{C}\right)$ & 6.0 & 20.0 & 12.9 & 3.0 & 23.3 & 31 \\
EC-lab* & 403.0 & 627.0 & 457.7 & 45.9 & 10.0 & 29 \\
$\mathrm{pH}-\mathrm{lab}$ & 7.04 & 7.87 & 7.65 & 0.17 & 2.2 & 29 \\
$\mathrm{Ca}(\mathrm{mg} / l)$ & 31.3 & 54.2 & 37.1 & 4.64 & 12.5 & 29 \\
$\mathrm{Mg}(\mathrm{mg} / \mathrm{l})$ & 9.0 & 15.1 & 10.5 & 1.27 & 12.1 & 29 \\
$\mathrm{Na}(\mathrm{mg} / l)$ & 37.4 & 55.0 & 42.8 & 3.48 & 8.1 & 29 \\
$\mathrm{~K}(\mathrm{mg} / l)$ & 5.22 & 7.88 & 6.40 & 0.53 & 8.3 & 29 \\
$\mathrm{Cl}(\mathrm{mg} / \mathrm{l})$ & 18.7 & 45.0 & 23.2 & 5.52 & 23.8 & 29 \\
$\mathrm{SO}_{4}(\mathrm{mg} / l)$ & 27.2 & 87.0 & 36.3 & 13.47 & 37.1 & 29 \\
$\mathrm{HCO}_{3}(\mathrm{mg} / l)$ & 171.0 & 213.0 & 188.7 & 9.71 & 5.1 & 29 \\
$\mathrm{SiO}_{2}(\mathrm{mg} / l)$ & 59.0 & 67.0 & 63.6 & 1.99 & 3.1 & 29 \\
$\mathrm{NO}_{3}(\mathrm{mg} / l)$ & 9.96 & 20.2 & 15.24 & 2.43 & 15.9 & 27 \\
\hline
\end{tabular}

* $\mu \mathrm{mhos} / \mathrm{cm} @ 25^{\circ} \mathrm{C}$

* SDEV/mean x 100

*** Number of observations

TABLE 4. SUMMARY OF RESULTS FROM WATEQDR FOR MEAN CANE SPRING CHEMISTRY.

\begin{tabular}{lclc}
\hline \multicolumn{2}{c}{ Physical Parameter } & \multicolumn{1}{c}{$\log$ - Saturation Index } \\
\hline pH-lab & 7.65 & Anhydrite & -2.89 \\
Temperature & $12.9^{\circ} \mathrm{C}$ & Calcite & -0.13 \\
$\log \mathrm{PCO}_{2}$ & -2.45 & Dolomite & -0.67 \\
& & Gypsum & -2.20 \\
\hline
\end{tabular}

content results from atmospheric and recharge-area soil-zone- $\mathrm{CO}_{2}$ inputs which initially lower the solution $\mathrm{pH}$ and make it more aggressive in dissolving the volcanic rocks. Sodium and calcium from plagioclase feldspars are much more abundant than potassium in solution because the potash feldspars are more resistant to chemical weathering. The higher sodium-to-calcium-molar ratio ( 2 to 1 ) can be most simply explained as reflecting the rhyodacitic and dacitic $(\mathrm{Na} / \mathrm{Ca}$ ratios in plagioclase $\mathrm{f} / \mathrm{d}$ spars between 5 to 1 and 1 to 1 ) composition of the Wahmonie and Salyer formation 
volcanics in the Cane Spring vicinity (Poole et al., 1965). That is not to say, however, that these ion concentrations are unaffected by processes of evaporation, sorption or exchange en route to the spring. Indeed, these processes are probably operative here, but evaluation of their relative importance is beyond the scope of the present study.

\section{TIME SERIES}

\section{Precipitation}

During the first part of the study period, no precipitation data were collected at Cane Spring; however, precipitation data are available from a National Weather Service (NWS) station $2 \mathrm{~km}$ northwest of the spring site. The NWS monitoring site has been in place near Cane Spring (Station \#76) since October 1964 and produced 23 complete years of record to date. This meteorological station is located at an elevation of $1,219 \mathrm{~m}(4,000 \mathrm{ft})$, approximately $18 \mathrm{~m}$ below the Cane Spring discharge point. NWS data from 40 sites on the NTS were analyzed by French (1986), including the Cane Spring Station. A summary of the precipitation data is presented for a period of record through 1985 (Table 5). Seasonal average precipitation statistics are also provided in this table. The reader should be aware that these data have been analyzed based on the following constraints.

1. All months with one or more days of missing data were eliminated.

2. All years with one or more months of missing data were eliminated.

3. The summer period is defined as May, June, July, August, and September; while the winter period is defined as October, November, December, January, February, March, and April (French, 1986, p. 9).

Precipitation data were collected at the Cane Spring discharge point from November 1985 to August 1987 by the Desert Research Institute (DRI). The precipitation gauge was not heated during the winter season due to access limitation to the site; therefore, winter measurements are inaccurate in the timing of precipitation measured during these periods of snowfall. The snow/water mass was generally as accurate as rainfall measurements since the snow-filled precipitation gauge would

TABLE 5. SUMMARY OF PRECIPITATION DATA FROM NWS CANE SPRING METEOROLOGICAL STATION $(\mathrm{cm})$.

\begin{tabular}{ccccccc}
\hline \multirow{2}{*}{$\begin{array}{c}\text { Complete Years } \\
\text { of Record }\end{array}$} & \multicolumn{2}{c}{ Annual Precipitation } & \multicolumn{2}{c}{ Summer } & \multicolumn{2}{c}{ Winter } \\
Mean & SDEV & Mean & SDEV & Mean & SDEV \\
\hline 21 & 20.80 & 9.42 & 5.97 & 4.29 & 14.83 & 8.58 \\
\hline
\end{tabular}


melt the day after the snow accumulated. These data will be used in the following sections for high-frequency interpretations and the NWS data will be used for interpreting low-frequency data.

The Cane Spring meteorological station (National Weather Service) showed a great deal of temporal variability during this study period. The winters of 1980-81 and 1983-84 were well below the winter average at the site over 21 years of record. The summer totals for 1986, 1981, and 1985 were well below the mean summer precipitation. Extreme monthly events also occurred during this study, including a summer storm in August 1983 when $14.8 \mathrm{~cm}$ (5.81 inches) of precipitation fell. This event was nearly 2.5 times greater than the mean summer season total. Such summer irregularities are primarily the result of summer convective type storms indicative of this region and are generally localized and widely scattered events.

\section{Discharge}

Spring discharge was measured with a stopwatch and volumetric cylinder each time the site was visited, approximately 63 measurements were taken (Appendix B). Excluding the field reconnaissance measurement taken on July 11, 1980 (277 days before the onset of this study), the mean measurement interval was 41 days (see Table 6). Discharge varied markedly during this study, but exhibited a general trend coincident with the seasonal precipitation previously described (Figure 4). Winter season discharge was nearly twice that of summer seasonal discharge, approximately $0.050 \mathrm{l} / \mathrm{sec}$ and $0.025 \mathrm{l} / \mathrm{sec}$, respectively.

An extremely high discharge event was observed on January 11, 1985 and was nearly 2.5 times greater than the mean discharge. This event is thought to correlate with the sudden melting of snow that accumulated during the two months prior to this flow response. However, detailed information related to the watershed conditions (including soil moisture, soil temperature, snow moisture content, weather conditions during the event, etc.) was not available. Therefore, the cause of this discharge

TABLE 6. CANE SPRING DISCHARGE SUMMARY STATISTICS FROM APRIL 1981 TO FEBRUARY 1988.

\begin{tabular}{ccccccc} 
& Min. & Max. & Mean & SDEV & Coef. Var. & $\mathrm{n}$ \\
\hline $\begin{array}{c}\text { Sample } \\
\text { Interval (days) } \\
\quad 19\end{array}$ & 157 & 41 & 23.1 & 56.3 & 62 \\
$\begin{array}{c}\text { Spring } \\
\text { Discharge }(/ / \mathrm{sec})\end{array}$ & 0.018 & 0.105 & 0.043 & 0.015 & 34.9 & 62 \\
\hline
\end{tabular}




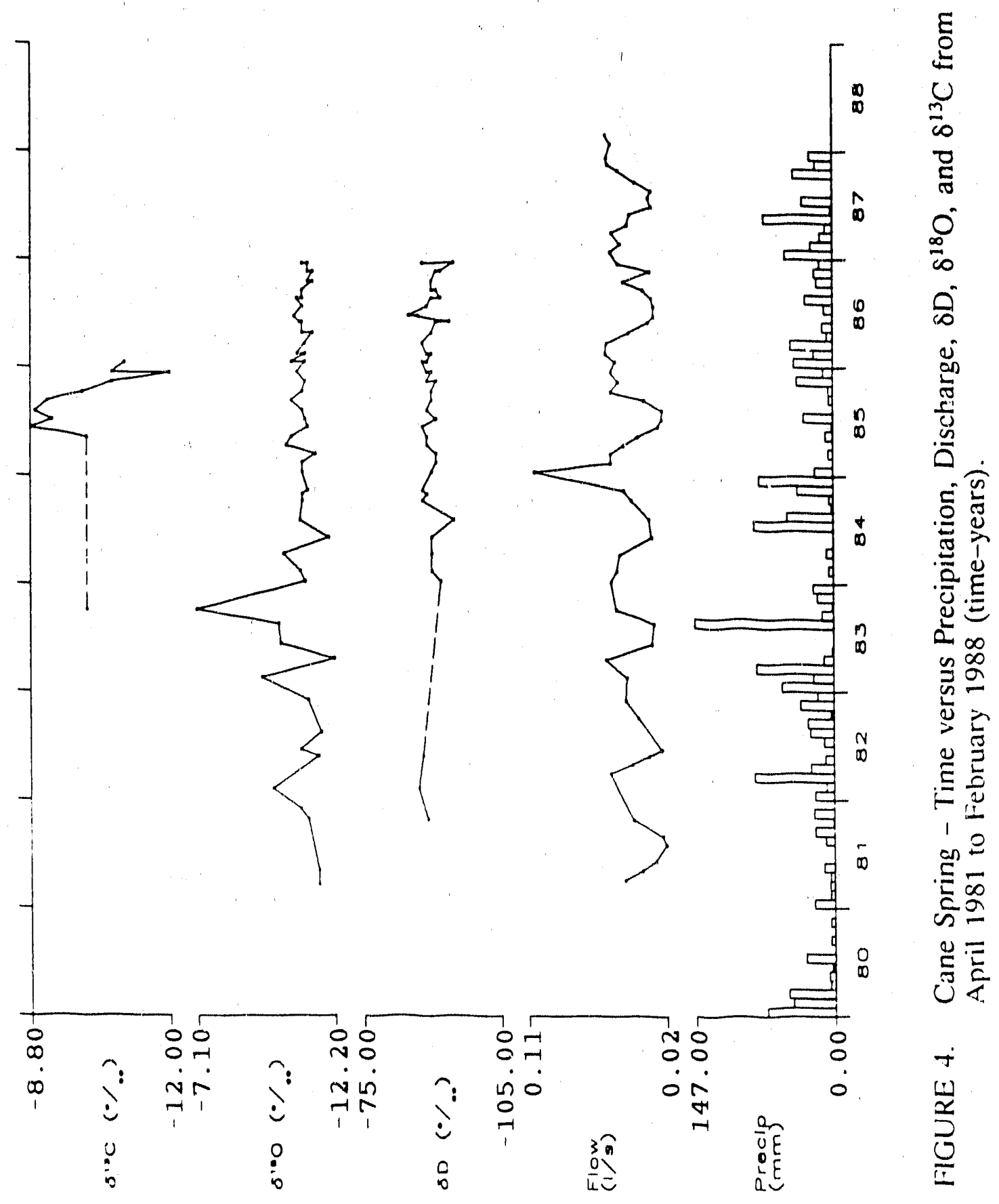


event can only be speculated and the effects and correlations with chemical parameters will be discussed in the next section.

\section{Ions}

Spring water chemistry samples were collected on 29 of the 62 visits to Cane Spring during this study (Appendix $\mathrm{C}$ ). Major cations and anions were measured from these samples and showed a wide range of values for each parameter as a function of time. These parameters were plotted as a function of time in Figure 5 , with time on the $x$-axis and each parameter plotted separately on the $y$-axis. Each $y$ sub-axis ranges from the minimum to the maximum observed for that variable during this study. A summary of the statistics for these parameters is listed in Table 3.

The range and deviation about the mean for most parameters was relatively small throughout the study period, with the exception of variations observed from a sample collected on January 11, 1985 (this extreme event was omitted from the mean chemical composition used in computer modeling). Several ions exceeded the mean concentrations by nearly two times, including increases in calcium, magnesium, sodium, chloride, and sulfate, and to a lesser extent, an increase in potassium. This anomalous event was coincident with an extreme discharge event previously described. Bicarbonate, silica, and nitrate ions were relatively unaffected during this time period. The only parameter that showed a significant variation during this period was EC; $\mathrm{pH}$ was relatively unchanged and the water temperature was unaffected by the event and seemed to follow its normal seasonal low temperature fluctuation. The summary statistics for these parameters are listed in Table 3.

Although the watershed conditions that produced the extreme discharge event are unknown, the observed chemical variation is thought to be controlled by salt dissolution. Water flowing through local aquifer systems of unconsolidated soil and fractured rocks is at quasi-chemical equilibrium with the aquifer minerals. However, during extreme discharge conditions, the water level within the aquifer rises above its equilibrium level and contacts minerals/salts. The dissolution of these minerals/salts can contribute to the TDS of the solution as observed in the above-mentioned case.

A geochemical computer model, SNORM, was used to approximate which salts that may have been dissolved to produce the elevated ionic concentrations observed. The average Cane Spring ionic composition, the composition from the extreme event, and the difference between the extreme event and the average compositions were used as input for SNORM. The results of this computer simulation are listed in Appendix E.

Based on this computer simulation, the mean spring water chemistry was derived from five major minerals (on a weight percent basis), including 62 percent 


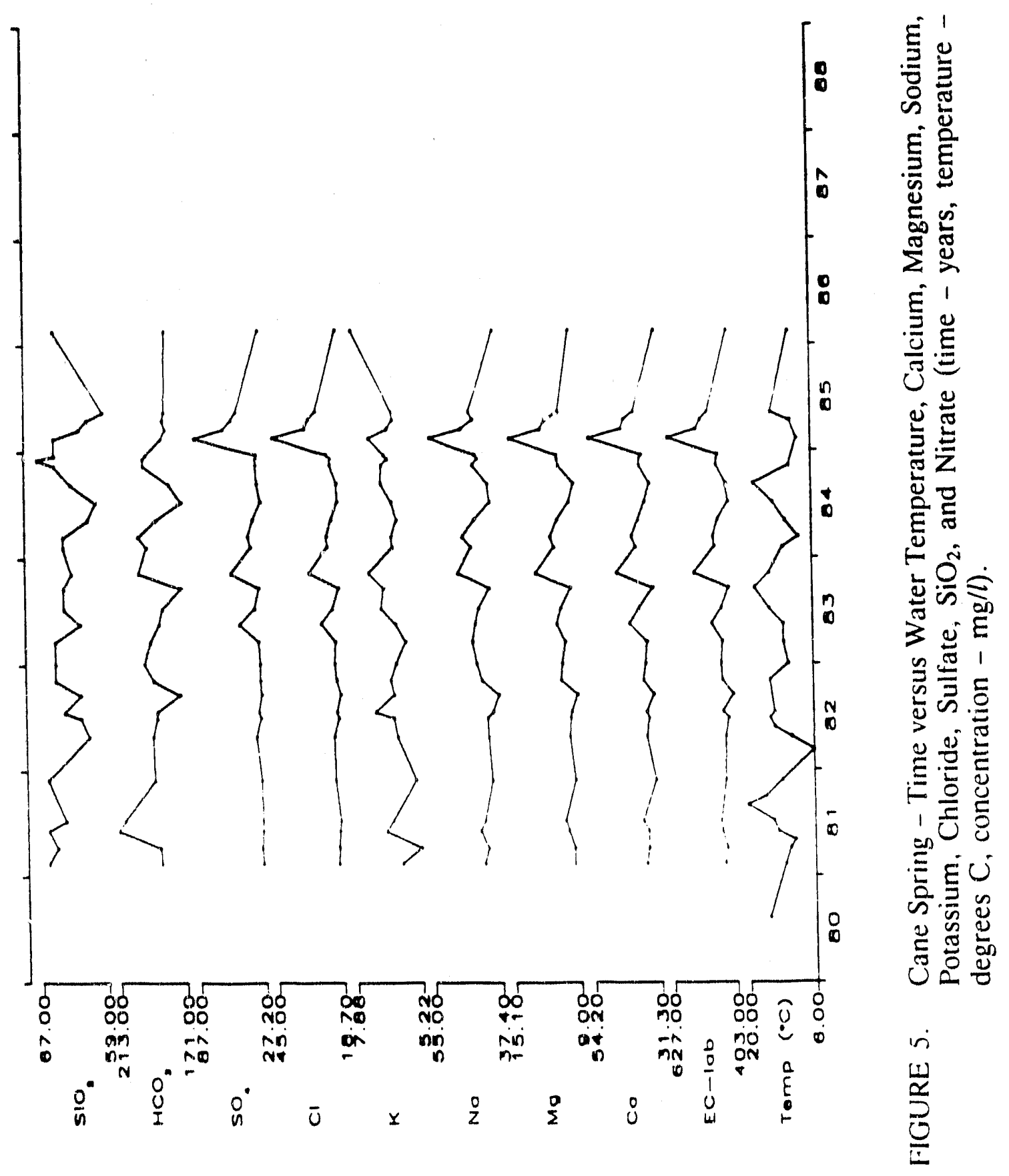


carbonate minerals (dolomite, pirssonite, and calcite), 22 percent sulfate minerals (thenardite), and 16 percent chloride minerals (halite). The extreme event, as computed by SNORM, is primarily the result of the dissolution of anhydrite $\left(\mathrm{CaSO}_{4}\right)$ and halite $(\mathrm{NaCl})$. Anhydrite and halite are commonly observed in fractures and soils. These two minerals account for approximately 80 percent, by weight, while the remainder is attributed to less common chloride and sulfide minerals.

\section{Isotopes}

Environmeñtal isotopes of hydrogen, oxygen, and carbon of Cane Spring discharge water were collected temporally during this study (Appendix D). Oxygen isotopes were analyzed on a fairly uniform sample interval (Table 6) and generally coincided with ion sample points (March 1981 to December 1986). The hydrogen isotope period was slightiy shorter, frum October 1981 to December 1986. However, not until January 1984 were all of the hydrogen isotope samples analyzed that coincided with the oxygen samples. Only 11 samples were anulyzed for carbon isotopes. Carbon isotope sample dates range from October 1983 to January 1986, with the densest sample collection occurring from May 1985 to January 1986.

The isotope ratios of $\delta \mathrm{D}, \delta^{18} \mathrm{O}$, and $\delta^{13} \mathrm{C}$ of Cane Spring water varied markedly during the study period (Table 7). The data are plotted as a function of time in Figure 4. Precipitation and spring discharge are also plotted on the figure for reference. An interesting trend was observed based on these data. A distinct $8^{18} \mathrm{O}$ enrichment in Cane Spring discharge was observed in October 1983. This peak was nearly $4 \%$ heavier than the average for the period of record, and occurred approximately two months after an anomalous precipitation event $(14.8 \mathrm{~cm}$ in August 1983), as discussed previously. Generally, summer precipitation is isotopically heavier than winter precipitation because of the temperature and storm track of the cloud mass that produces the rain.

The oxygen isoiope ratios of precipitation collected from Site STA, approximately $17 \mathrm{~km}$ from Cüıs Spring, lends support to the theory of seasonal isotope

TABLE 7. CANE SPRING ISOTOPE CHEMISTRY SUMMARY STATISTICS FROM MARCH 1981 TO DECEMBER 1986.

\begin{tabular}{lcccccc}
\hline Variable & Min. & Max. & Mean & SDEV & Coef. Var. & $\mathrm{n}$ \\
\hline$\delta \mathrm{D}$ & -95.0 & -85.0 & -89.8 & 1.9 & 2.1 & 48 \\
$\delta^{18} \mathrm{O}$ & -12.2 & -7.1 & -10.9 & 0.7 & 6.4 & 59 \\
$\delta^{13} \mathrm{C}$ & -12.0 & -8.8 & -10.1 & 1.0 & 9.9 & 11 \\
\hline
\end{tabular}


variation (Figure 6). An enrichment of approximately $7 \%$ o was observed in precipitation at Site ST4, coincident with the August 1983 precipitation event. Cane Spring responded two months later with a $4 \%$ shift, which is thought to be the recharge water. Due to the irregular sample frequency, the exact lag period is unknown.

The isotope time-series plot (Figure 4) suggests a slight enrichment of oxygen and hydrogen isotopes during the summer and a slight depletion during the winter; however, no statistically significant correlation exists during the period of record. A three-dimensional comparison of oxygen isotopes versus hydrogen isotopes versus time was conducted and no obvious trends were observed. The oxygen and hydrogen isotopes plot just off the world meteoric water line, suggesting slight evaporation at Cane Spring (Figure 7).

Five water samples for tritium analysis were collected from Cane Spring during the study; all samples were below analytical detection limits $(<160 \mathrm{pCi} / l$ for one sample and $<16 \mathrm{pCi} / l$ for four enriched samples). Background environmental tritium levels prior to nuclear surface testing were at or below approximately $16 \mathrm{pCi} / l$; therefore, it is presumed that the average Cane Spring water is greater than 30 years old.

In March 1982, a water sample was collected for ${ }^{14} \mathrm{C}$ analysis to further estimate the water age. The dissslved carbon irom approximately $100 \mathrm{l}$ of water was precipitated with strontium chloride and sodium hydroxide. This precipitant was submitted to the radiocarbon laboratory of Teledyne Isotopes (1982). The sample yielded a $\delta^{14} \mathrm{C}$ value of $-71.9 \pm 9 \%$. This equals a percent modern carbon (PMC) of 92.8 based on the following equation (Fritz and Fontes, 1980, p. 51):

$$
\mathrm{PMC}=\left|\frac{\delta^{14} \mathrm{C}}{10}+100\right|
$$

The water age can then be calculated with the following equation (Fritz and Fontes, 1980, p. 53):

$$
\begin{aligned}
\text { Age (years) } & =-\frac{t_{1 / 2}}{\ln 2} \ln \frac{P M C}{100} \\
\text { where, } \quad t_{1 / 2} & =5,730 \text { years } \\
\text { or, } \quad \frac{t_{1 / 2}}{\ln 2} & =8,267 \text { years }
\end{aligned}
$$

The calculated uncorrected average age for Cane Spring water is approximately 600 years before present. 


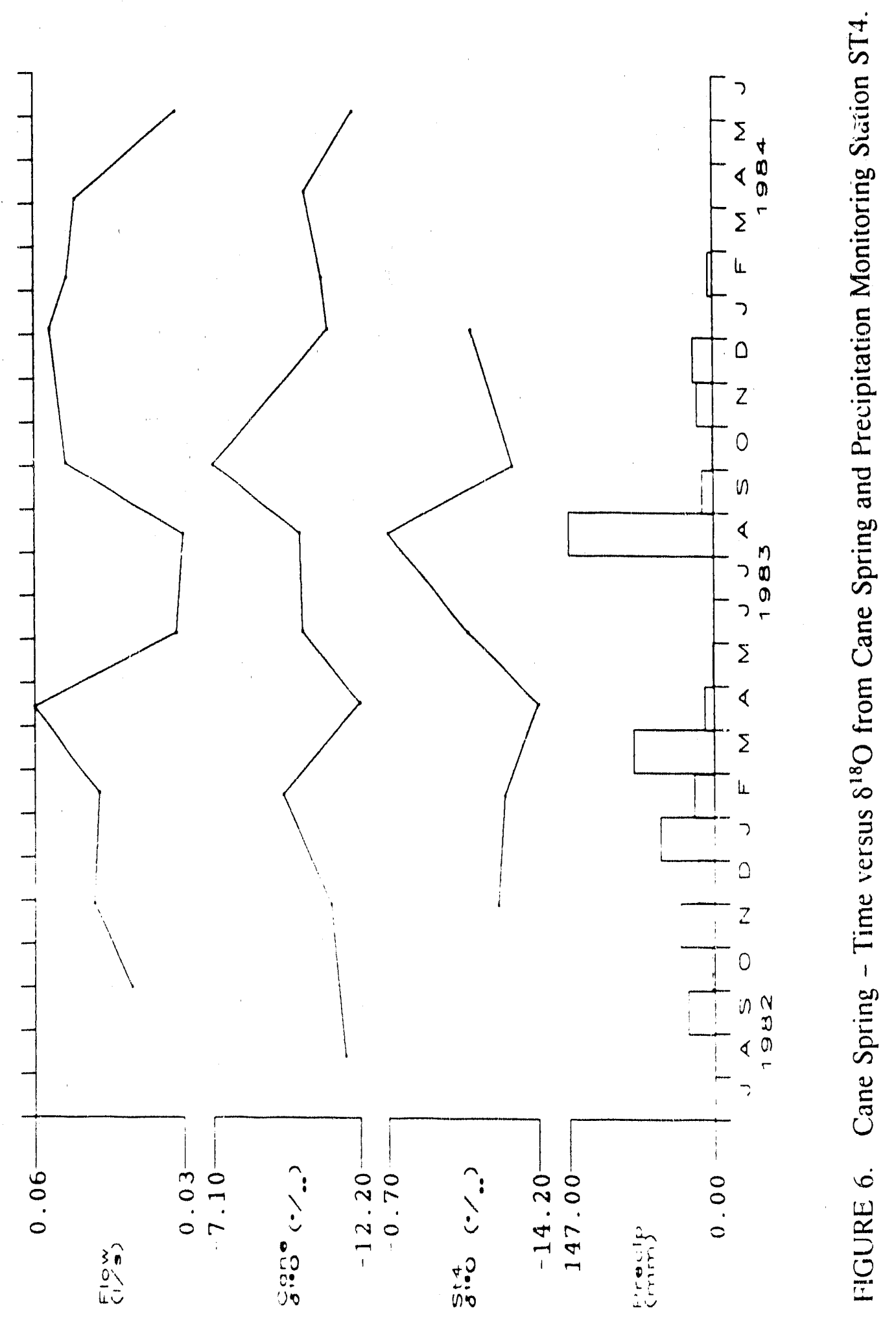




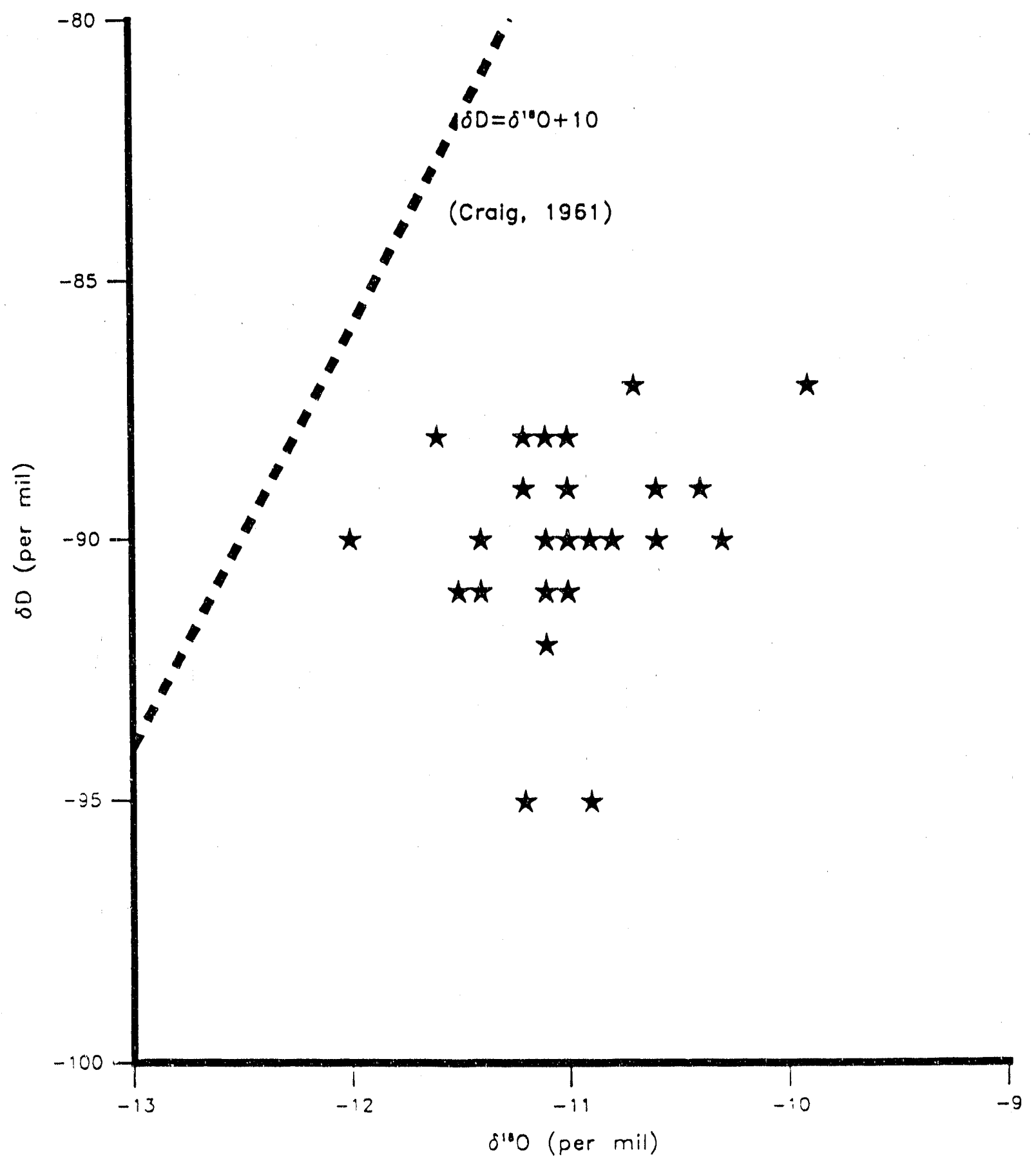

FIGURE 7. Cane Spring $-\delta D$ versus $\delta^{18} \mathrm{O}$ from October 1981 to December 1986. 
As the ${ }^{14} \mathrm{CO}_{2}$ enters the groundwater system, many reactions take place, including: reactions with plants in the soil zone, exchange with brackish water, exchange with soil $\mathrm{CO}_{2}$, reactions with soil water, and mixing with soil $\mathrm{CaCO}_{3}$. To approximate the isotopic fractionation that occurs during these reactions, a $\delta^{13} \mathrm{C}$ correction factor is used. The following equation and assumptions are used to correct the ${ }^{14} \mathrm{C}$ age:

$$
\begin{aligned}
\frac{a_{\Sigma}^{14}}{a_{0}^{14}} & =\frac{\delta_{\Sigma}^{13}-\delta_{1}^{13}}{\delta_{0}^{13}-\delta_{1}^{13}} \\
a_{\Sigma}^{14} & =\text { Water PMC } \\
a_{0}^{14} & =\text { Corrected PMC } \\
\delta_{\Sigma}^{13} & =\text { Water } \delta^{13} \mathrm{C} \\
\delta_{1}^{13} & =\text { Rock } \delta^{13} \mathrm{C} \\
\delta_{0}^{13} & =\text { Biogenic } \delta^{13} \mathrm{C}
\end{aligned}
$$

Assume: $\delta_{1}^{13}=0.0 \%$ oo and $\delta_{0}^{13}=-12 \%$ (Boughton, 1986).

Rewrite the equation:

$$
a_{0}^{14}=\frac{a_{\Sigma}^{14}}{\delta_{\Sigma}^{13} /-12^{\circ} \%}
$$

A $\delta^{13} \mathrm{C}$ analysis was run from the same water in conjunction with the ${ }^{14} \mathrm{C}$ analysis and yielded a value of $-10.9 \%$. Entering this data into the above equation yields a corrected PMC of 102 . This suggests that the aquifer is composed of water older than 30 years and younger than approximately 600 years. The large groundwater age range is presumably the result of mixing of older aquifer water with recent recharge waters, which in this area starts near 100 PMC.

\section{MICROLOGGER STATISTICS}

Several interesting relationships/phenomena have been observed during this study as described in previous sections. This section is related primarily to the computerized data collected from November 1985 to August 1987. Data measurements were made every five minutes and were averaged each hour and stored in the micrologger permanent memory. Precipitation measurements were made by totaling the number of tenths-of-an-inch that occurred in a 15-minute period. Summary statistics for these data are listed in Appendix F.

These data are plotted together as daily averages versus time in Figure 8. Micrologger failures due to lightning and electronic malfunction produced data gaps 


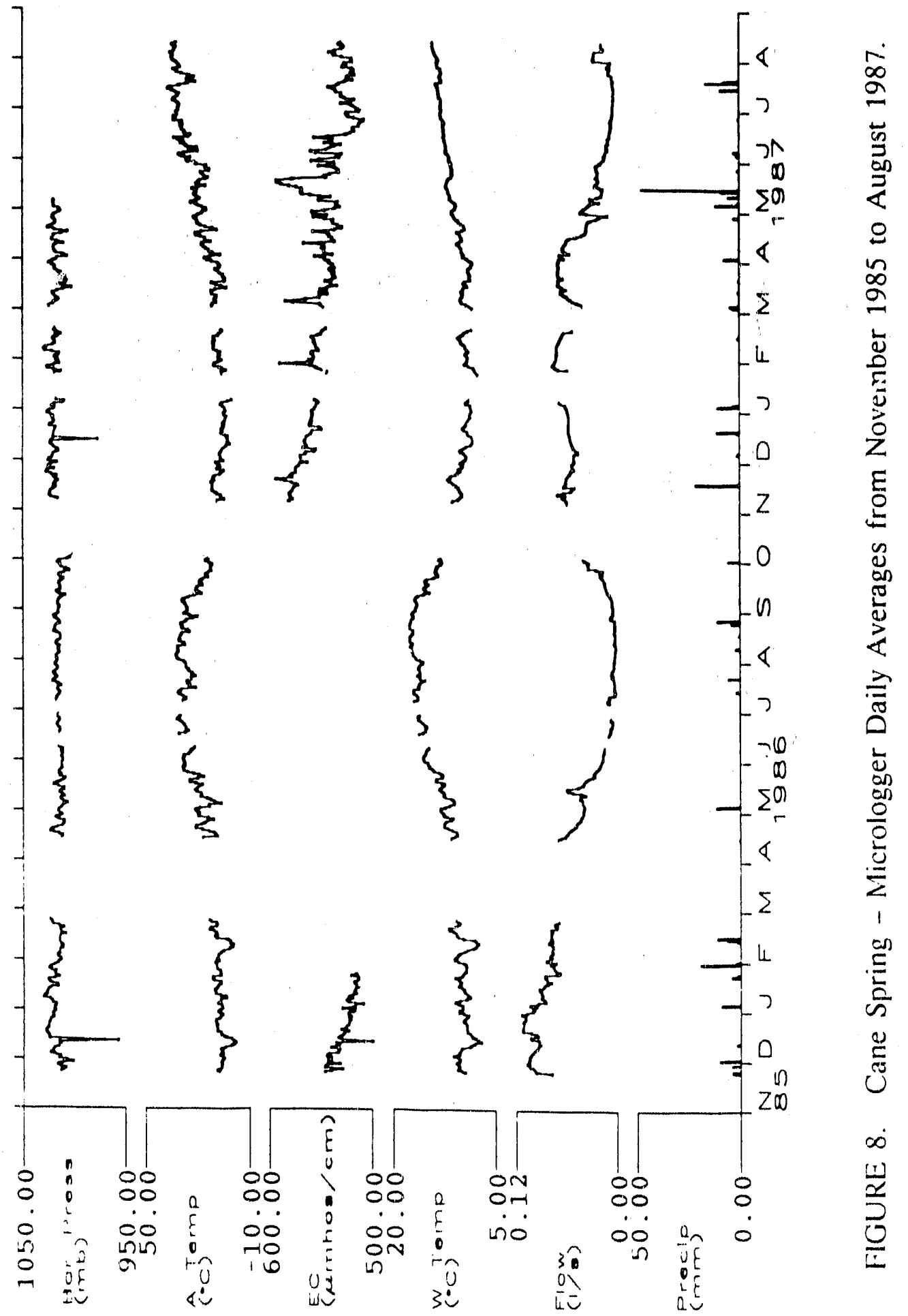


during the period of record; therefore, long-term trends may be impossible to discern. An obvious correlation in this figure is the high correlation between air and water temperature trends. The coefficient of variation for air temperature is nearly 30 percent, while water temperature is only about 4 percent. This range in variation is due to seasonal warming of the soil around the spring (low frequency) compared to the diurnal fluctuation in air temperature (high frequency). A simple cross-correlation of daily averages yields greater than 90 percent correlation between these two parameters with water temperature lagging air temperature variation by about 24 hours.

There is also a significant correlation between water temperature and EC. The correlation coefficient between these parameters at zero lag was approximately 85 percent. The EC readings presented have been normalized to $25^{\circ} \mathrm{C}$. The coefficient of variation is about 4 percent for each variable. Detailed laboratory experiments were conducted to eliminate potential sources for error in these measurements. Heating and cooling of the electronics did not appreciably alter EC observations; likewise, heating and cooling of the fluid did not show significant deviation when normalized to $25^{\circ} \mathrm{C}$. The variations of specific ions cannot be determined by a parameter such as $\mathrm{EC}$; however, it is assumed that chemical variations are the result of recycling of simple salts resulting from diurnal water temperature fluctuations.

Spring discharge responded rapidly to intense precipitation events. An example of this was observed in May 1987 (Figure 9). Two intense precipitation events occurred during this period. A summary of recorded precipitation during this period is listed in Table 8 (the minimum and maximum precipitation that fell in any $15-\mathrm{min}$ ute period is also listed).

A distinct decrease in flow can be noted in Figure 9 on May 7. This is believed to be the result of blockage in the pipe conducting water from the adit to the weir box. The volume of water stored in the spring pool was eventually discharged as the pipe gradually flushed over a one-day period resulting in the increased flow. Althoug: significant precipitation orcurred during this period, a correlative flow response cannot be discerned. However, a flow response did result from the precipitation event of May 15 and 16. A detailed plot of this precipitation event and flow is shown in Figure 10. There was an approximate 10-hour lag time from the onset of precipitation (May 15, 2015 hours) until the first evidence of increased spring discharge (May 16, 0600 hours). Peak flow was observed at 1300 hours (May 16) and flow recession began; however, flow recession stopped at 1600 hours and began rising again. This second increase was coincident with a second precipitation event which started approximately 10 to 10.5 hours previous to the flow response (0530 to 0600 hours, May 16). This flow response peaked at 0900 hours on May 17. The first flow response lasted 7 


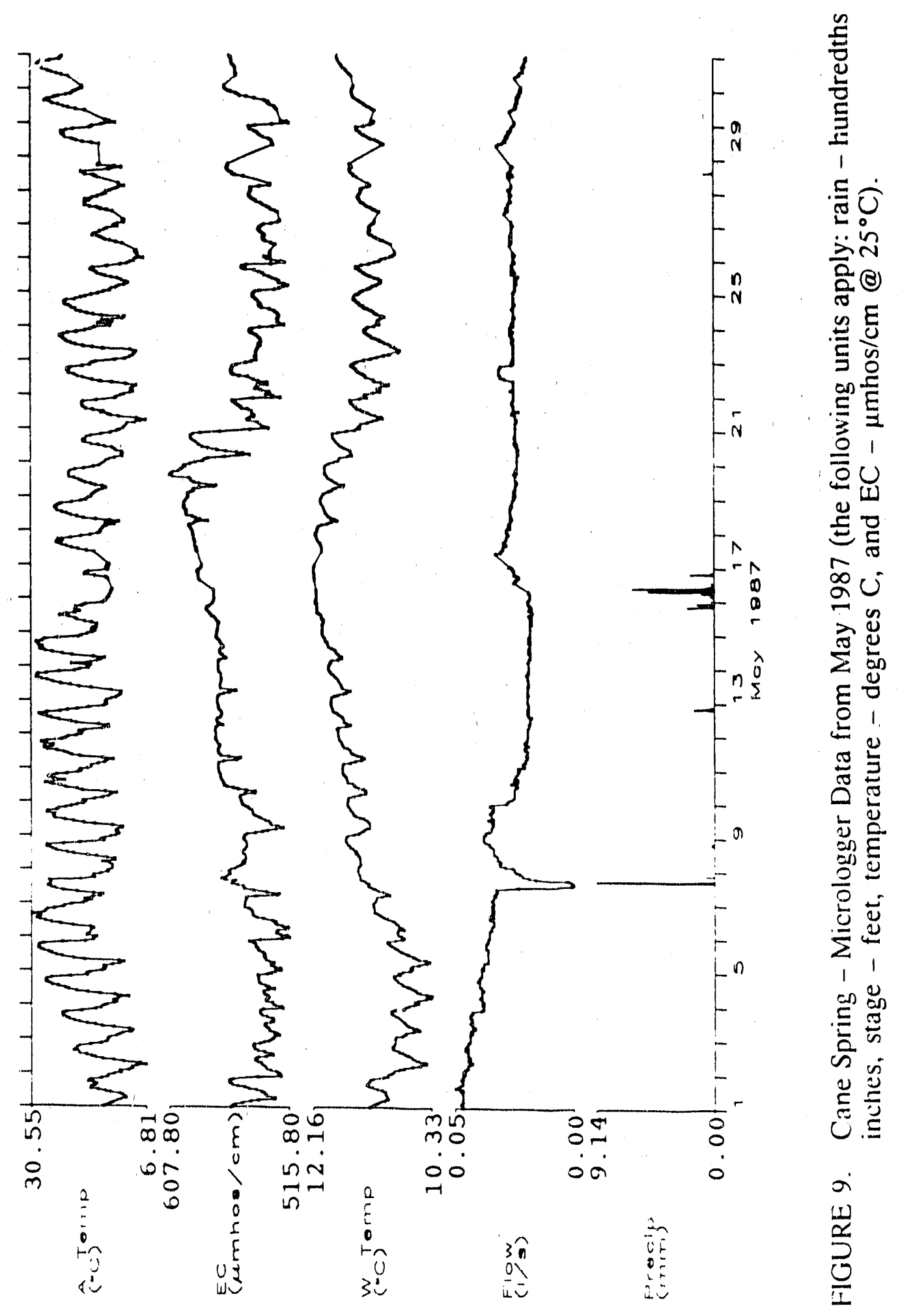



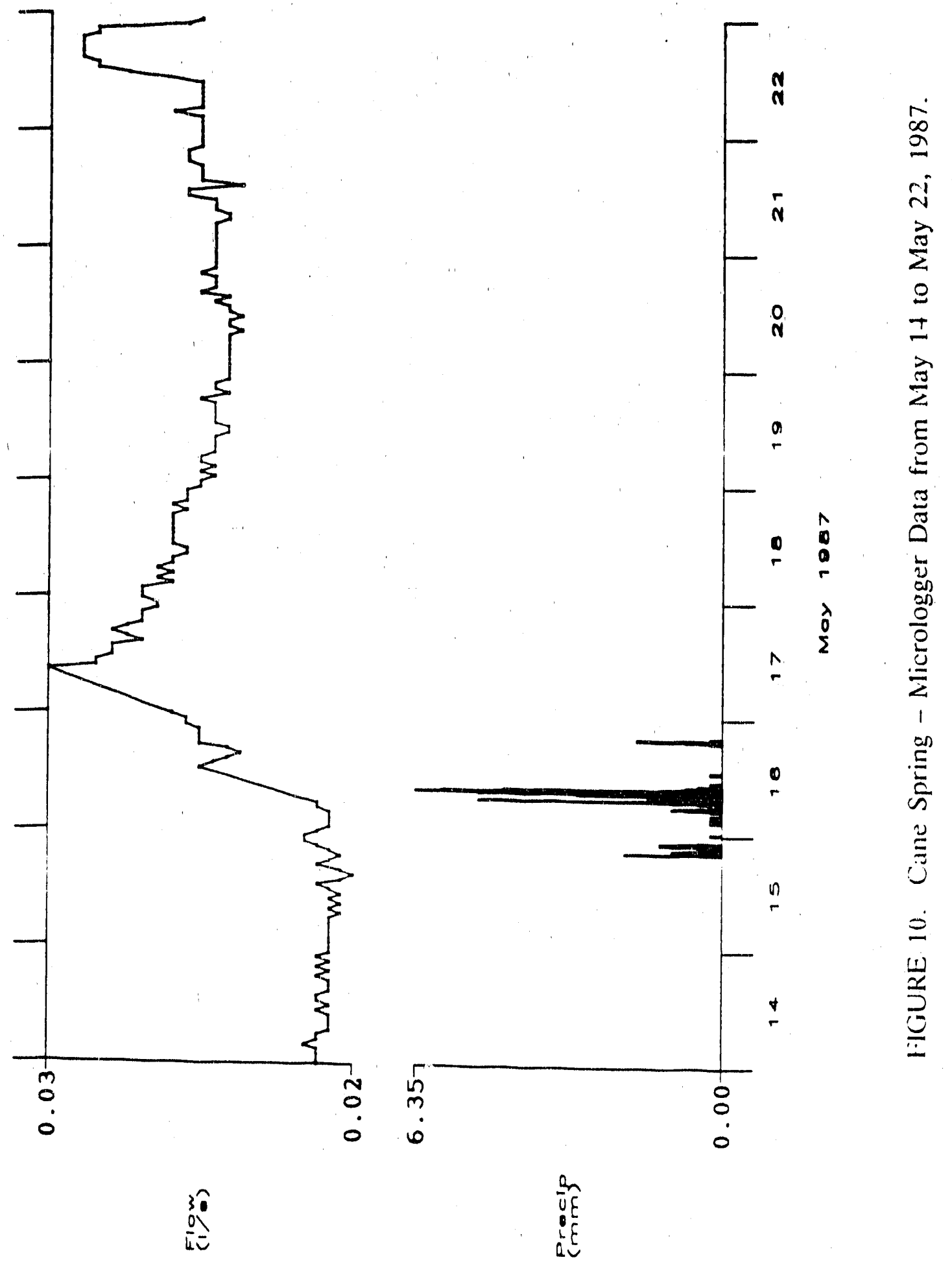
TABLE 8. SUMMARY OF PRECIPITATION AT CANE SPRING MAY 1987.

\begin{tabular}{lcccc}
\hline Date & $\begin{array}{c}\text { Minimum } \\
(\mathrm{cm})\end{array}$ & $\begin{array}{c}\text { Maximum } \\
(\mathrm{cm})\end{array}$ & $\begin{array}{c}\text { Sum } \\
(\mathrm{cm})\end{array}$ & $\begin{array}{c}\text { Duration } \\
(\text { minutes })\end{array}$ \\
\hline May 7 & 0.08 & 0.91 & 1.12 & 45 \\
May 8 & 0.03 & 0.03 & 0.10 & 60 \\
May 12 & 0.03 & 0.15 & 0.53 & 120 \\
May 15 & 0.03 & 0.20 & 0.84 & 105 \\
May 16 & 0.03 & 0.64 & 4.75 & 540 \\
May 28 & 0.03 & 0.08 & -13 & 45 \\
& 0.03 & 0.91 & 7.47 & 960 \\
\hline
\end{tabular}

hours, while the second lasted about 17 hours. Tnese durations correspond to the mass of observed precipitation from each event, $0.84 \mathrm{~cm}$ and $4.75 \mathrm{~cm}$, respectively.

\section{SUMMARY}

From the inception of the study (July 11,1980) to the termination of data collection (August 11, 1987), the site had been visited 63 times to collect time-series da:

Twenty-nine water samples were collected and analyzed for major ations and anions. Fifty-nine environmental isotope samples were also analyzed. During the period of record, the site was visited roughly every 41 days for nearly seven years. The chuinical composition of Cane Spring water is characterized as a sodium-calciumbicarbonate-type water.

Conclusions made about the physiography of Cane Spring can be broken down into two categories as a function of the data-collection/sample interval. The low-frequency data (41-day interval) were used to estimate the long-term effects of recharge to the aquifer, while the high-frequency data (one-hour interval) were used to estimate the timing from the start of precipitation until the pressure pulse was observed at the discharge point. Both of these data types required extreme precipitation events to initiate a response at the discharge point.

An extreme precipitation event in August $1983(14.8 \mathrm{~cm})$ showed only a slight response as increased spring discharge and increased concentrations of cations and anions (calcium, magnesium, sodium, bicarbonate). The flow response occurred almost immediately (less than 41 days) and based on the high-frequency data response observed in May 1987, the pressure pulse probably came through less than one day after the precipitation event. However, the chemical response lagged the precipitation by about two months; increases in nearly all major cations and anions were 
observed at this time, as well as a nearly $4 \%$ on enrichment in $8^{18} \mathrm{O}$. This isotopic enrichment in spring water is coincident with the $7 \%$ enrichment in precipitation of the August 1983 event. The minimum precipitation threshold is difficult to determine due in part to the lack of extreme precipitation events during micrologger monitoring. However, the event on May 7, 1987 did not produce a discernible flow response (due in part to a theorized flow restriction) and the May 16, 1987 event produced a discharge response. Therefore, a safe assumption can be made that the minimum threshold is less than $4.75 \mathrm{~cm}$ over a 540 -minute duration and greater than $1.12 \mathrm{~cm}$ over a 45-minute duration.

These data suggest that the aquifer responds to recharge very quickly, indicative of a shallow semi-confined aquifer. Based on the tritium and carbon age determinations, it is further believed that this aquifer is local to the Skull Mountain area. The hypothesized aquifer model will be further described in the discussion section. 


\section{WHITEROCK SPRING}

\section{SETTING}

Whiterock Spring is located at $37^{\circ} 12^{\prime} 05^{\prime \prime} \mathrm{N}$. latitude, $116^{\circ} 07^{\prime} 54^{\prime \prime} \mathrm{W}$. longitude at an elevation of $1,532 \mathrm{~m}(5,025 \mathrm{ft})$ in Area 12. The spring discharges from the south-facing slope on rolling foothills of the Belted Range, approximately $1.5 \mathrm{~km}$ northeast of the Rainier Mesa Road - Tippipah Highway intersection (Figure 11). The spring has been developed with two shallow adits and water was transmitted approximately $50 \mathrm{~m}$ to a weir box via a $4-\mathrm{cm}$-diameter plastic pipe.

The spring issues from the Tertiary Indian Trails formation. Near Whiterock Spring, this formation is about $20 \mathrm{~m}$ thick and primarily composed of zeolitic nonbedded tuff with scattered pebbles of quartzite, dense lava, gneiss, and schist (Gibbons et al., 1963). Within the immediate vicinity of the spring there exists Pennsylvanian Eleana formation, which is composed of quartzite, sandstone, argillite, and conglomerate (in varying percentages locally).

The structural geology of the area is very subtle with several small normal faults in the Indian Trails formation and in the Eleana formation. A shallow synclinal feature exists in the tuffaceous rocks approximately $0.3 \mathrm{~km}$ west of Whiterock Spring and trends northeast-southwest. These structures do not appear to impede or centralize groundwater flow in the area.

The indian Trails formation is characterized as a tuff aquitard and the Eleana formation is characterized as the upper clastic aquitard; the interstitial permeability of the tuff members and transmissibility of the clastic rocks are considered negligible; however, higher permeability zones may exist locally (Winograd and Thordarson, 1975). Recharge is derived from the low hills around the spring and may extend $3 \mathrm{~km}$ or more north toward Twin Peaks. Based on this information, groundwater presumably flows along paths of primary and local secondary permeability. The discharge location is thought to coincide with the thinning of the tuff formation (aquifer), bounded at the base by the low permeability clastic rocks.

\section{GEOCHEMISTRY}

Whiterock Spring water is characterized as a sodium-bicarbonate-type water. The mean epm concentration of sodium over the study period was nearly six times more than calcium, the next most concentrated cation. Bicarbonate ion was two times more than sulfate and four times more than chloride. The basic statistics for aqueous constituents in the 48 samples are given in Table 9. The mean chemical composition of the water was run through the computer program WATEQDR to estimate the geochemical characteristics of the observed aqueous species. A summary of the results from this program is listed in Table 10. 


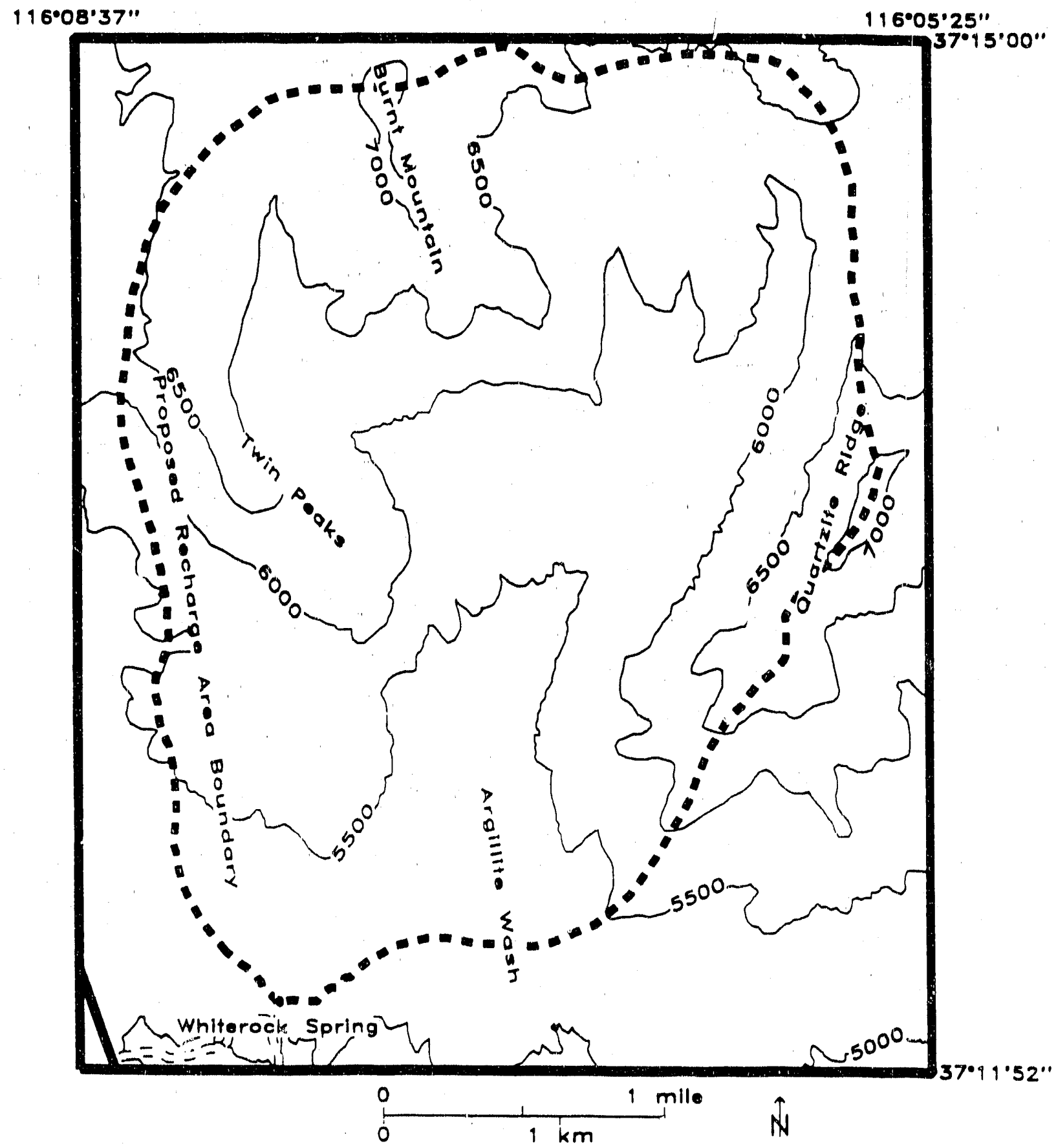

FIGURE 11. Location Map of Whiterock Spring. Elevation Contours (feet), Paved Roads (solid), Dirt Roads (open-dashed), and Recharge Boundary (dashed) are Shown. 
TABLE 9. WHITEROCK SPRING ION CHEMISTRY SUMMARY STATISTICS FROM JANUARY 1981 TO APRIL 1985.

\begin{tabular}{lcccccc}
\hline \multicolumn{1}{c}{ Variable } & Min. & Max. & Mean & SDEV & Coef. Var. ** ${ }^{* * *}$ \\
\hline Temp. $\left({ }^{\circ} \mathrm{C}\right)$ & 7.6 & 19.0 & 13.5 & 2.6 & 19.3 & 49 \\
EC-lab* & 186.0 & 268.0 & 238.9 & 18.1 & 7.6 & 48 \\
$\mathrm{pH}-\mathrm{lab}$ & 6.69 & 7.66 & 7.44 & 0.18 & 2.4 & 48 \\
$\mathrm{Ca}(\mathrm{mg} / \mathrm{l})$ & 4.3 & 9.6 & 5.9 & 0.9 & 15.3 & 48 \\
$\mathrm{Mg}(\mathrm{r} \cdot \mathrm{g} / \mathrm{l})$ & 0.2 & 1.8 & 0.8 & 0.4 & 50.0 & 48 \\
$\mathrm{Na}(\mathrm{mg} / \mathrm{l})$ & 33.5 & 51.2 & 43.6 & 3.6 & 8.3 & 48 \\
$\mathrm{~K}(\mathrm{mg} / \mathrm{l})$ & 5.26 & 7.65 & 6.48 & 0.63 & 9.7 & 48 \\
$\mathrm{Cl}(\mathrm{mg} / \mathrm{l})$ & 8.1 & 13.2 & 10.7 & 1.2 & 11.2 & 48 \\
$\mathrm{SO}(\mathrm{mg} / \mathrm{l})$ & 25.8 & 41.3 & 32.3 & 4.1 & 12.7 & 48 \\
$\mathrm{HCO}_{3}(\mathrm{mg} / \mathrm{l})$ & 68.0 & 86.5 & 81.0 & 4.5 & 5.6 & 48 \\
$\mathrm{SiO}_{2}(\mathrm{mg} / \mathrm{l})$ & 43.0 & 49.0 & 46.5 & 1.2 & 2.6 & 48 \\
$\mathrm{NO}_{3}(\mathrm{mg} / \mathrm{l})$ & 2.62 & 9.30 & 6.63 & 1.28 & 19.3 & 46 \\
\hline
\end{tabular}

* $\mu \mathrm{mhos} / \mathrm{cm} @ 25^{\circ} \mathrm{C}$

* SDEV/mean x 100

*** Number of observations

TABLE 10. SUMMARY OF RESULTS FROM WATEQDR FOR MEAN WHITEROCK SPRING CHEMISTRY.

\begin{tabular}{lcll}
\hline \multicolumn{2}{c}{ Physical Parameter } & \multicolumn{2}{c}{$\log$ - Saturation Index } \\
\hline $\mathrm{pH}$-lab & 7.44 & Anhydrite & -3.01 \\
Temperature & $13.5^{\circ} \mathrm{C}$ & Calcite & -1.44 \\
$\log \mathrm{PcO}_{2}$ & -2.59 & Dolomite & -3.61 \\
& & Gypsum & -2.92 \\
\hline
\end{tabular}

The mean spring chemistry has a $\mathrm{PCO}_{2}$ level approximately one order of magnitude above atmospheric. The dominate sulfate minerals are three times undersaturated. Likewise, the major carbonate minerals are well undersaturated. 


\section{TIME SERIES}

\section{Frecipitation}

Precipitation data were not collected at Whiterock Spring until the installation of a micrologger in December 1985 by DRI. The closest precipitation monitoring station is nearly $7.5 \mathrm{~km}$ west of Whiterock, atop Rainier Mesa. This station (A,rea 12 Mesa \#84) has been monitored by the NWS since March 1959 and has recorded 17 complete years of data. The meteorological station is located at an elevation of $2,283 \mathrm{~m}$ $(7,490 \mathrm{ft})$, approximately $750 \mathrm{~m}$ above the Whiterock Spring discharge point. Due to the large elevation difference, the mass accumulation is probably not correlative between sites. However, it is assumed the timing is correlative, with the exception of summer convective storms which are generally localized events. Summary statistics of NWS data were produced by French (1986) and are listed in Table 11.

The monthly totals are plotted in Figures $12 \mathrm{a}$ and $12 \mathrm{~b}$. Several months showed that extreme events produced seasonal precipitation totals higher than average, including: March storms in 1982 and 1983, which produced winter totals 25 percent and 150 percent over normal, respectively; and an August event in 1983 that alone was nearly 80 percent over the summer total. These extreme events can produce pulses within the aquifers.

\section{Discharge}

Spring discharge was measured at two discharge points within the Whiterock Spring discharge area (Whiterock East - WRE and Whiterock West - WRW). Measurements were made with a stopwatch and volumetric cylinder each time the site was visited, totaling 63 measurements each (Appendix B). The mean sample interval was 40 days (Table 12).

WRW showed nearly three times more variation than WRE. Discharge variations in both springs coincided well with precipitation events as previously described (Figures 12a and 12b). Precipitation events produced discharge pulses in March 1982, April 1983, October 1983, August 1984, and January 1985.

TABLE 11. SUMMARY OF PRECIPITATION DATA FROM AREA 12 MESA METEOROLOGICAL STATION (cm).

\begin{tabular}{ccccccc}
\hline $\begin{array}{c}\text { Complete Years } \\
\text { of Record }\end{array}$ & Annual Precipitation & \multicolumn{2}{c}{ Summer } & \multicolumn{2}{c}{ Winter } \\
Mean & SDEV & Mean & SDEV & Mean & SDEV \\
\hline 17 & 29.54 & 12.83 & 9.91 & 3.78 & 25.36 & 13.16 \\
\hline
\end{tabular}




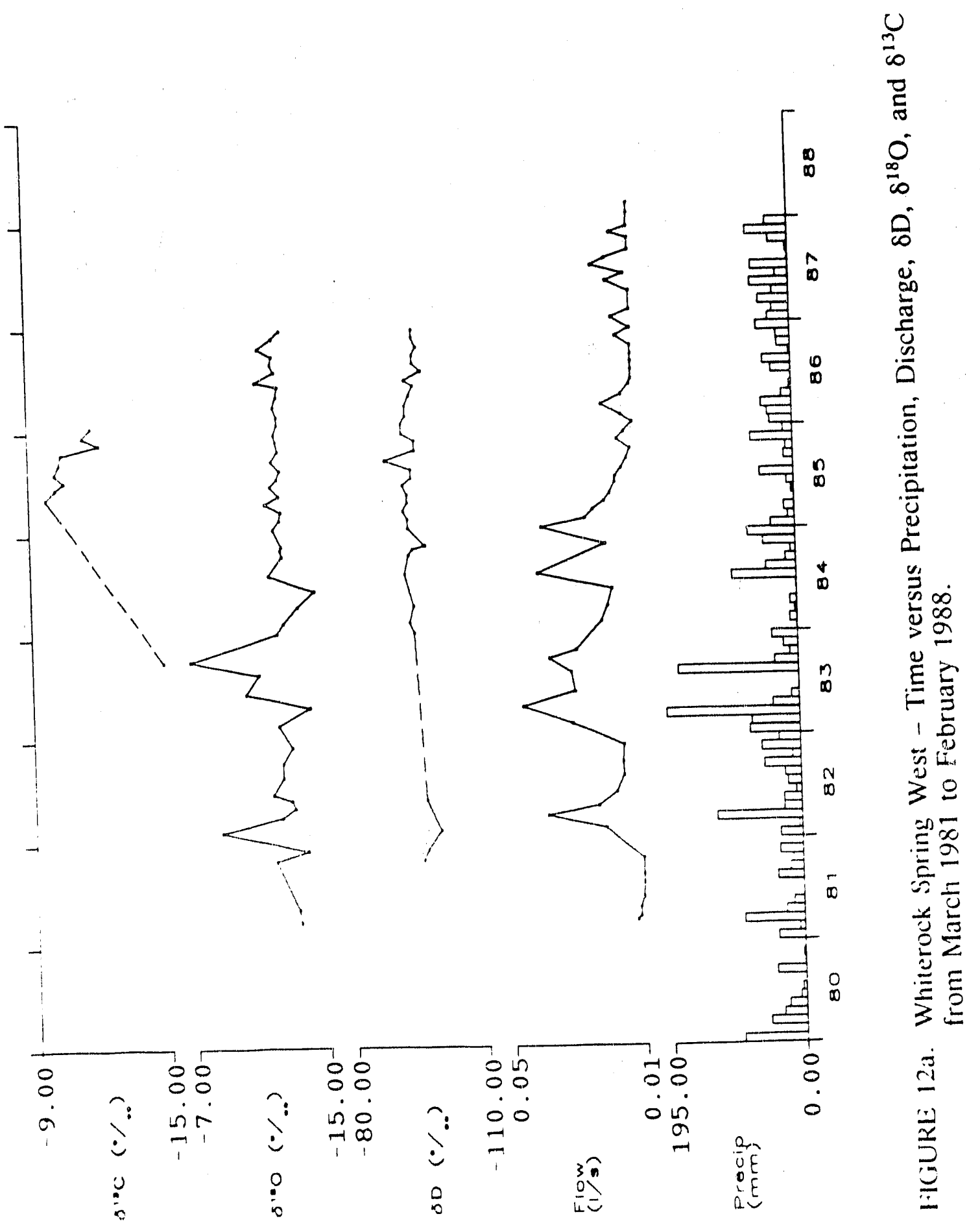




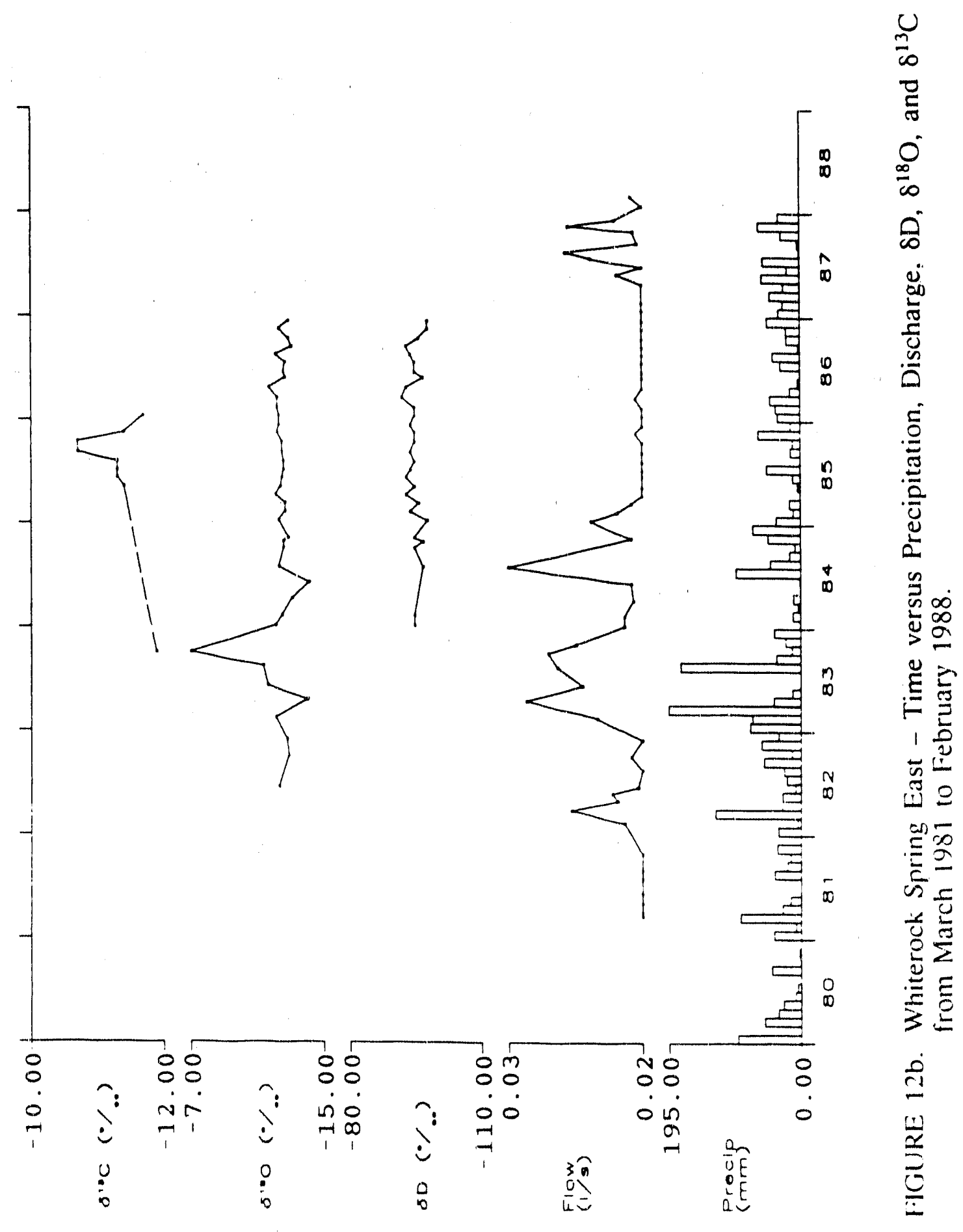


TABLE 12. WHITEROCK SPRING DISCHARGE SUMMARY STATISTICS FROM MARCH 1981 TO FEBRUARY 1988.

\begin{tabular}{ccccccc}
\hline & Min. & Max. & Mean & SDEV & Coef. Var. & $\mathrm{n}$ \\
\hline $\begin{array}{c}\text { Sample } \\
\text { Interval (days) } \\
\quad \text { Spring }\end{array}$ & 13 & 107 & 40 & 18.4 & 46.0 & 63 \\
$\begin{array}{c}\text { Discharge }(l / \mathrm{sec}) \\
\quad \text { WRE } \\
\quad \text { Spring }\end{array}$ & 0.880 & 1.870 & 1.202 & 0.214 & 17.8 & 63 \\
$\begin{array}{c}\text { Discharge }(l / \mathrm{sec}) \\
\text { WRW }\end{array}$ & 0.440 & 2.730 & 1.028 & 0.572 & 55.6 & 63 \\
\hline
\end{tabular}

The exact lag interval between precipitation and flow response cannot be determined, but graphically appears to be less than 40 days (one sample interval). A statistical analysis will be covered in a later section to further approximate this lag interval.

\section{Ions}

Spring chemistry samples were collected on 32 of the 63 visits to WRW and on 16 of the 63 visits to WRE during this study (totaling 48 samples) (Appendix C). Major cations and anions were measured from these samples and showed a wide range of values for each parameter as a function of time. Minor variations were also observed between WRE and WRW. Data from WRW are plotted on Figure 13a, with time on the $x$-axis and each parameter plotted separately on the $y$-axis. Each $y$ sub-axis ranges from the minimum to the maximum observed for that variable during this study. Equally, data from WRE are plotted on Figure 13b. Although WRW exhibited nearly three times more variation in discharge than WRE, the chemical response was very similar between springs. A noticeable anomaly occurred December 3, 1982: calcium at WRW showed a peak of $9.6 \mathrm{mg} / \mathrm{l}$, while WRE showed little variation from values before and after this sample at $5.5 \mathrm{mg} / l$. This sample was taken during a low discharge period.

A definitive increase in several parameters was observed in May 1982. Noticeable increases were observed in the following parameters: calcium, magnesium, potassium, chloride, and bicarbonate. This peak coincided with a slightly increased $\mathrm{pH}$, at slightly elevated water temperature, and occurred approximately two months after dominate precipitation fell. Discharge was receding at this time after peaking about one month earlier. 


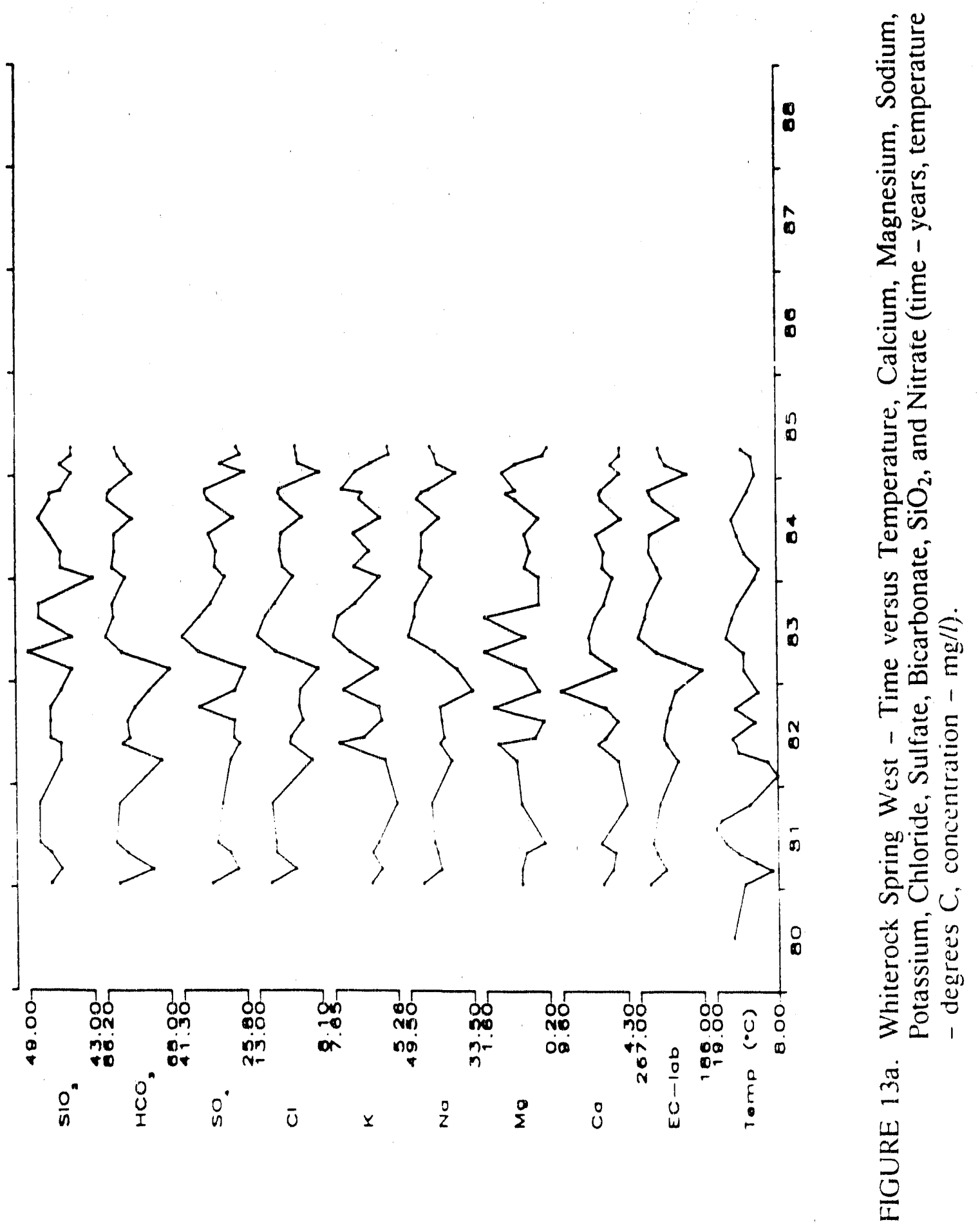




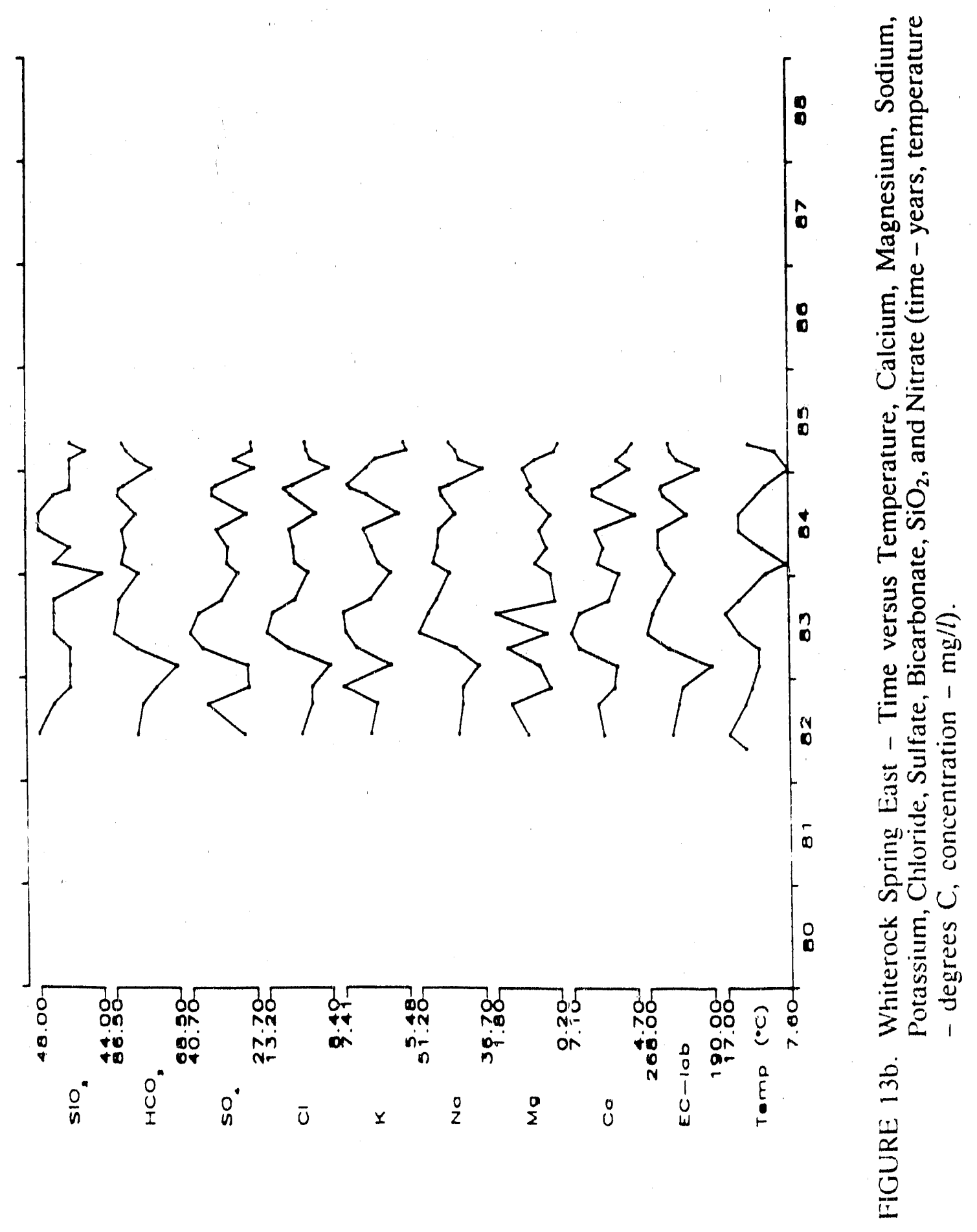


Samples collected from February 1983 to October 1983 (four samples from each spring) outlined the most distinct chemical trend observed during this study. A broad-spiked trend was observed during this time frame; increases were observed in calcium, potassium, chloride, sulfate, and bicarbonate. Sharp increases in sodium and magnesium were also observed. However, magnesium showed an interesting double peak during the period, the leading edge of this trend coincided with March 1983 precipitation and resultant increased discharge. Another anomalous precipitation month, August 1983, rnay be responsible for the second peak in potassium.

It is assumed that extreme discharge events elevate the water level within the aquifer. Water then presumably comes in contact with a variety of minerals/salts. The dissolution of these minerals may account for some of the observed variations. A computer simulation was run to estimate what normative salts the water may be at equilibrium with and to estimate which minerals may have contributed to the aforementioned chemical pulse. The results from the computer program SNORM are listed in Appendix E. Based on this computer simulation, the mean spring water (excluding the anomalous chemical pulse) is composed of six major minerals (on a weight basis), including: 51 percent carbonate minerals (burkeite, trona, pirssonite, and dolomite); 36 percent sulfate minerals (burkeite and aphthitalite); and 13 percent chloride minerals (halite). The extreme event, as computed by SNORM, was primarily the result of dissolution of thenardite $\left(\mathrm{Na}_{2} \mathrm{SO}_{4}\right)$, pirssonite $\left(\mathrm{Na}_{2} \mathrm{Ca}\left(\mathrm{CO}_{3}\right)_{2}\right.$. $\left.2 \mathrm{H}_{2} \mathrm{O}\right)$, and halite $(\mathrm{NaCl})$. These three minerals account for approximately 90 percent, by weight.

A chemical dilution, or trough, was observed in June 1984, coinciding with a high discharge event. This discharge is thought to be the result of local recharge due to precipitation during the same month. The chemical dilution may be the result of surface flow contamination of the samples. The weir box is situated in a stream bed which sustains intermittent flow and is dry most of the year. However, it is possible for stream flow to mix with spring water near the spring adits and at the weir box. This response was most noticeable at WRE, but was also observed at WRW.

\section{Isotopus}

Environmental isotopes were collected from WRE and WRW during this study (Appendix D). At the initiation of this study, samples were orly collected at W'RW. Oxygen isotopes were analyzed fairly uniformly during the study period (Table 12); samples generally coincided with ion samples (March 1981 to December 1986 for WRW and June 1982 to December 1986 for WRE). The period of record for hydrogen isotopes is slightly shorter (October 1981 to December 1986 for WRW and January 1984 to December 1986 for WRE). Not until January 1984 was hydrogen analyzed on 
a regular basis along with the oxygen isotopes. Even fewer carbon isotope samples were analyzed (October 1983 to January 1986, with 10 samples from WRW and 9 from WRE). However, the densest sample collection occurred from May 1985 to January 1986 for both sites. A summary of the observed temporal variation is listed in Tables 13a and 13b (WRW and WRE, respectively).

The data are plutted as a function of time in Figures 12a and 12b (WRW and WRE, respectively). A distinct $\delta^{18} \mathrm{O}$ enrichment was observed at WRW in February 1982; a sample from WRE was not taken on this date. A similar enrichment phenomena was observed at both sites in October 1983 . The 1982 peak was nearly $4 \%$ heavier than the mean at WRW and correlates with a depletion in $8 \mathrm{D}$ of nearly $11 \%$ lighter than the mean. However, this phenomenon does not appear to correlate with any recorded precipitation event or flow response. Conversely, the 1983 peak was nearly $10 \%$ heavier than the means of WRW and WRE, and appears to lag an August 1983 precipitation event by about 2.5 months.

Unfortunately, $\delta \mathrm{D}$ values were not analyzed for this sample period. This enrichment and apparent lagged correlation with a precipitation event is very similar to the event described at Cane Spring at a similar time period (Figure 6).

Generally, the isotopic signature of seasonally variant storms follows an enrichment during the summer and a depletion during the winter. A minor depletion of

TABLE 13a. WHITEROCK SPRING WEST ISOTOPE CHEMISTRY SUMMARY STATISTICS FROM MARCH 1981 TO DECEMBER 1986.

\begin{tabular}{lcccccc}
\hline Variable & Min. & Max. & Mean & SDEV & Coef. Var. & $\mathrm{n}$ \\
\hline$\delta \mathrm{D}$ & -100.0 & -89.0 & -95.0 & 1.9 & 2.0 & 35 \\
$\delta^{18} \mathrm{O}$ & -14.6 & -2.6 & -12.3 & 1.7 & 13.6 & 49 \\
$\delta^{13} \mathrm{C}$ & -18.5 & -9.8 & -11.6 & 2.6 & 22.1 & 10 \\
\hline
\end{tabular}

TABLE 13b. WHITEROCK SPRING EAST ISOTOPE CHEMISTRY SUMMARY STATISTICS FROM NIARCH 1981 TO DECEMBER 1986.

\begin{tabular}{lcccccc}
\hline Variable & Min. & Max. & Mean & SDEV & Coef. Var. & $\mathrm{n}$ \\
\hline$\delta \mathrm{D}$ & -98.0 & -92.0 & -95.0 & 1.6 & 1.6 & 30 \\
$\delta^{18} \mathrm{O}$ & -14.1 & -2.0 & -12.3 & 1.7 & 14.2 & 40 \\
$\delta^{13} \mathrm{C}$ & -11.9 & -10.7 & -11.3 & 0.4 & 3.5 & 9 \\
\hline
\end{tabular}


$2 \%$ in $\delta^{18} \mathrm{O}$ below the mean was observed at botr sites in April 1983. This is presumably the result of a gradual snowmelt infiltration and, therefore, cannot be associated with a distinct precipitation event. However, the grad sal increase in flow would suggest that recharge was entering the system for several months prior to the isotopic response.

A three-dimensional comparison of oxygen isotopes versus hydrogen isotopes versus time was conducted and yielded no obvious trends. A standard plot of oxygen versus hydrogen isotopes shows most of the data near the world meteoric water line (Craig, 1961), with the exception of a few outliers from WRW (Figure 14).

Four tritium samples were collected from WRW and three from WRE. The first sample at WRW was unenriched and was below detection limit $(<160 \mathrm{pCi} / l)$. Enriched samples yielded measurable tritium at both sites, ranging from $41 \mathrm{pCi} / l$ to 80 at WRW and from $19 \mathrm{pCi} / l$ to 32 at WRE. The temporal variation appears to be correlated with atmospheric variations observed by Trudeau (1979) for water that is approximately 30 years old, accounting for natural decay (Figure 15).

\section{MICROLOGGER STATISTICS}

This section is related primarily to the computerized data collected from December 1985 to January 1988. Data measurements were made every five minutes and were averaged each hour and stored in the micrologger permanent memory. Precipitation measurements were made by totaling the number of tenths-of-an-inch that occurred in a 15-minute period. Summary statistics for these data are listed in Appendix $\mathrm{F}$.

The stage measurements were taken at the weir box and are a sum of WRE and WRW discharge. The EC and water temperature were measured at WRW. These data are plotted together as daily averages versus time in Figure 16. Micrologger failures due to lightning and electronic malfunction produced data gaps during the period of record. An obvious correlation in this figure is the high correlation between air and water temperature. The coefficient of variation tor air temperature was approximately 80 percent, while water temperature is only about 15 percent. This damping is a function of the seasonal warming of the soil around the spring (low frequency) compared to the diurnal fluctuation in air temperature (high frequency). A simple cross-correlation of daily averages yields greater than 88 percent correlation between these two parameters with water temperature lagging air temperature variation by about one hour.

There also exists a fair correlation between water temperature and EC. The correlation coefficient between these parameters was approximately 50 percent, with 


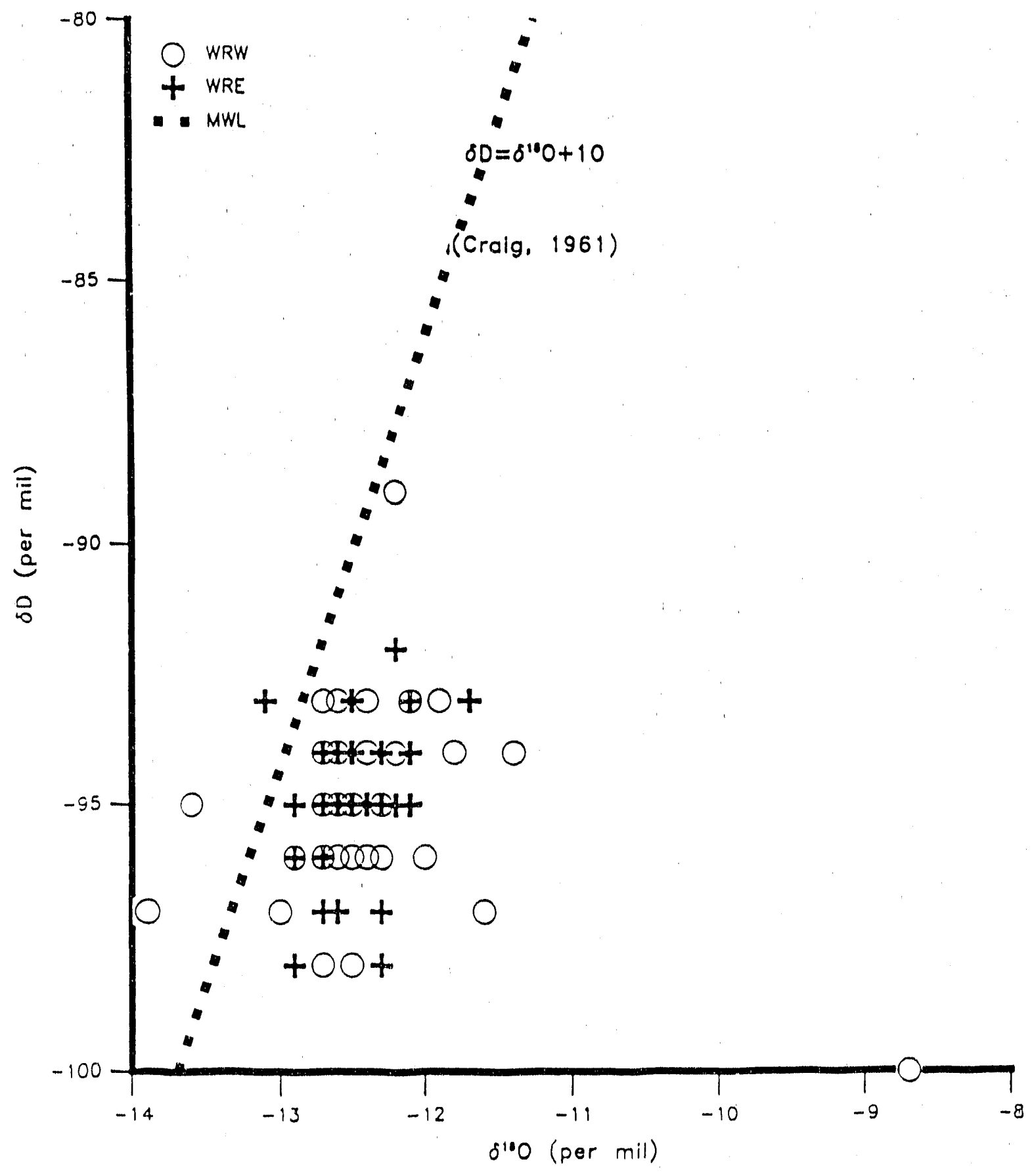

FIGURE 14. Whiterock Spring $-\delta \mathrm{D}$ versus $\delta^{18} \mathrm{O}$ from October 1981 to December 1986. 


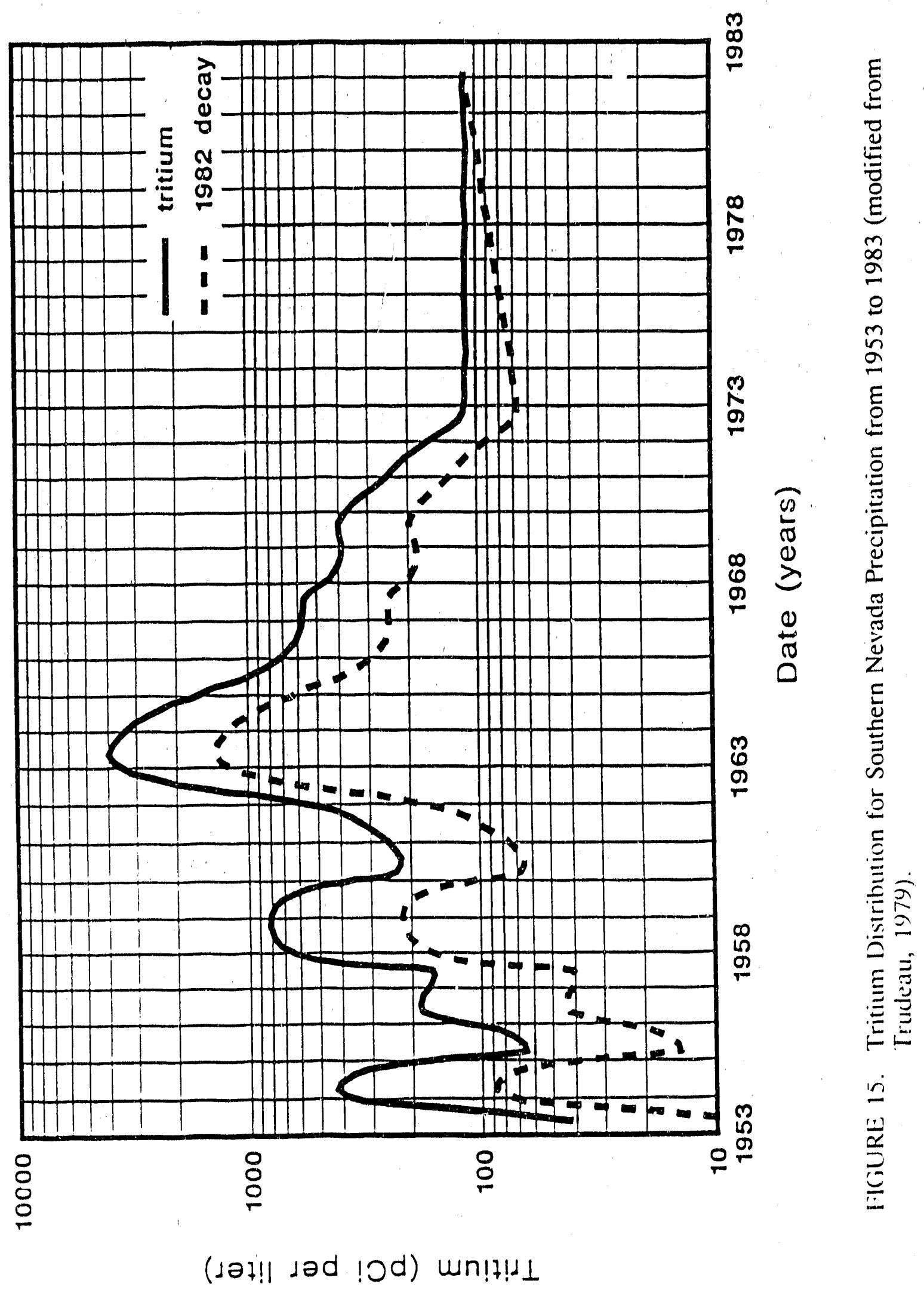




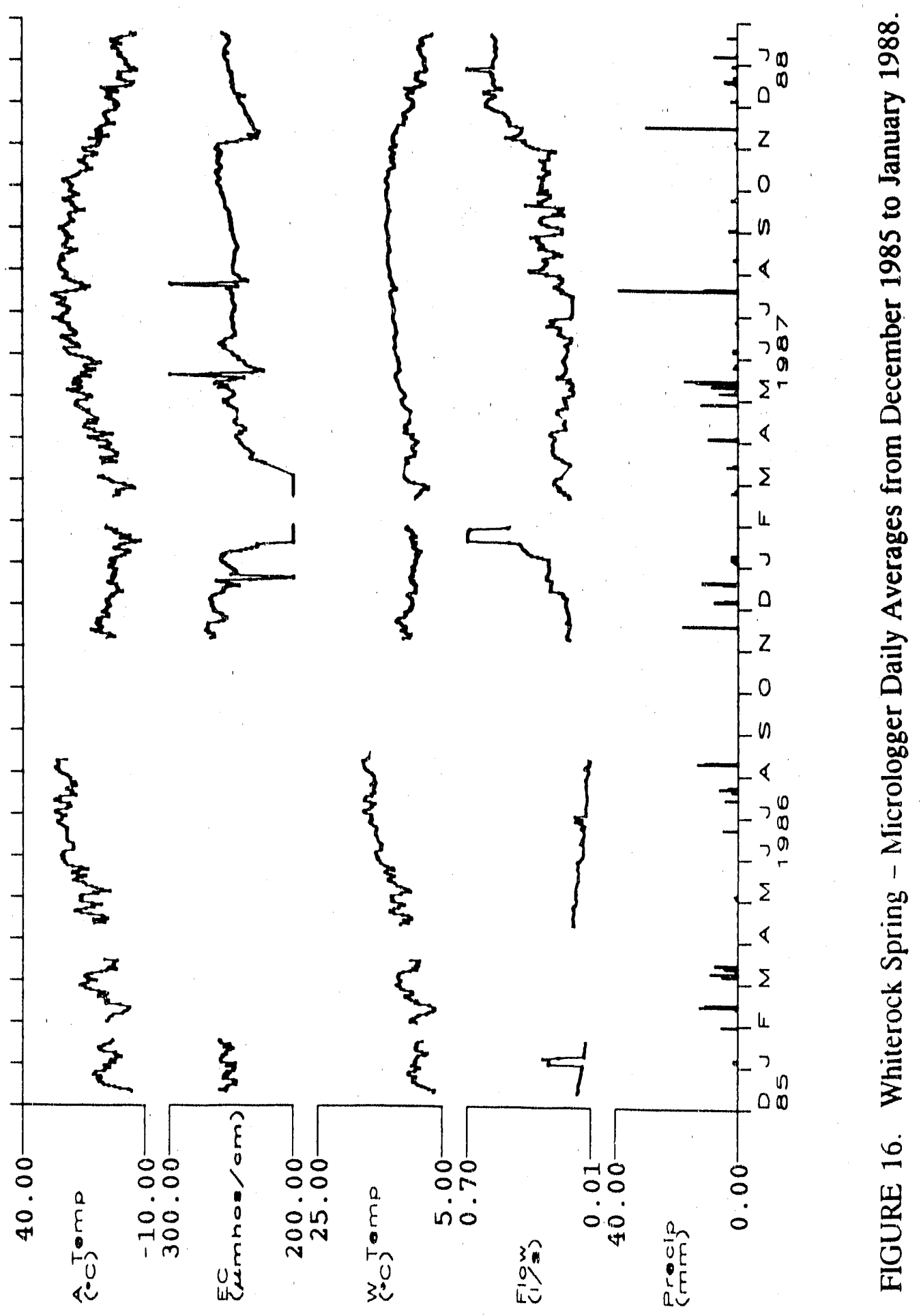


EC lagging water temperature by 18 hours. The EC readings presented have been normalized to $25^{\circ} \mathrm{C}$. The coefficient of variation for EC is nearly double that of water temperature.

Spring discharge responded rapidly to precipitation events. Two examples of rapid discharge response were observed in 1987. The first example occurred in May 1987 (Figure 17). A summary of the recorded precipitation is listed in Table 14 (the minimum and maximum precipitation that fell during any 15 -minute period are also listed). Several minor variations in stage and EC occurred during May and are attributed to debris blocking the weir and/or minor responses to low-intensity precipitation events. However, a significant change in stage and EC was observed, starting on May 16 , in response to precipitation that started falling on May 15. A detailed plot of this time period is plotted in Figure 18. There was an approximate 2-hour lag time from the onset of precipitation (May 15, 2015 hours) until the first evidence of increased discharge (May 15, 2200 hours). Peak flow was observed about five hours after precipitation began. Flow recession began abruptly, but ceased (May 16, 0600 hours) due to a second precipitation event. Peak flow was again observed at 1600 hours, approximately 12 hours after the onset of this second precipitation event. EC declined slightly starting May 15 at about 2200 hours and bottomed out May 16 at about

TABLE 14. SUMMARY OF PRECIPITATION AT WHITEROCK SPRING MAY 1987.

\begin{tabular}{lcccc}
\hline Date & $\begin{array}{c}\text { Minimum } \\
(\mathrm{cm})\end{array}$ & $\begin{array}{c}\text { Maximum } \\
(\mathrm{cm})\end{array}$ & $\begin{array}{c}\text { Sum } \\
(\mathrm{cm})\end{array}$ & $\begin{array}{c}\text { Duration } \\
(\text { minutes })\end{array}$ \\
\hline May 7 & 0.03 & 0.23 & 0.63 & 135 \\
May 9 & 0.03 & 0.08 & 0.10 & 30 \\
May 10 & 0.03 & 0.03 & 0.03 & 15 \\
May 12 & 0.03 & 0.28 & 0.89 & 135 \\
May 13 & 0.03 & 0.15 & 0.30 & 45 \\
May 14 & 0.03 & 0.03 & 0.03 & 15 \\
May 15 & 0.03 & 0.15 & 1.35 & 225 \\
May 16 & 0.03 & 0.18 & 1.75 & 510 \\
May 17 & 0.03 & 0.03 & 0.03 & 15 \\
May 26 & 0.03 & 0.03 & 0.15 & 90 \\
May 27 & 0.03 & 0.03 & 0.10 & 60 \\
May 28 & 0.03 & 0.05 & 0.10 & 45 \\
& 0.03 & 0.28 & 5.46 & 1.320 \\
\hline
\end{tabular}




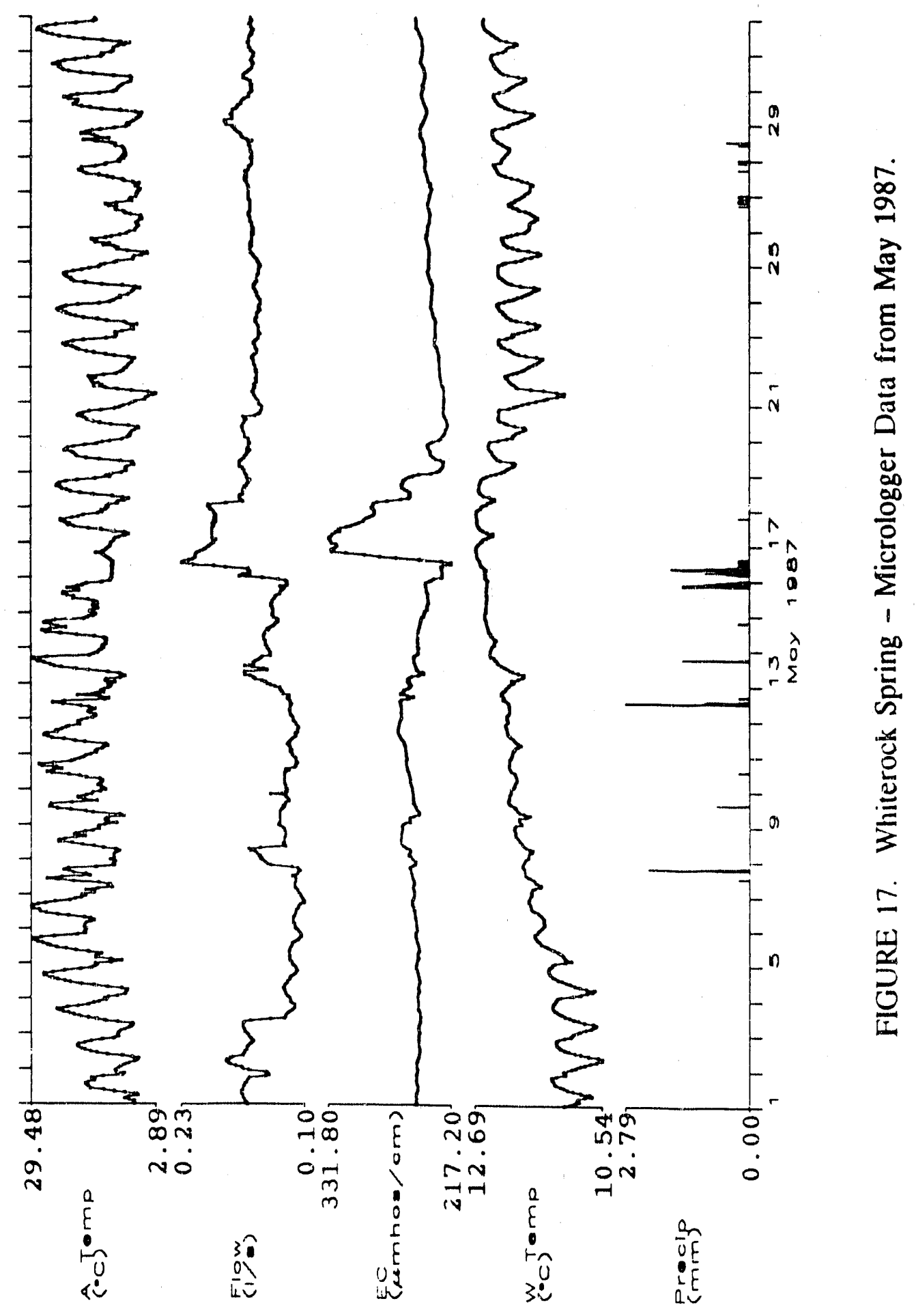




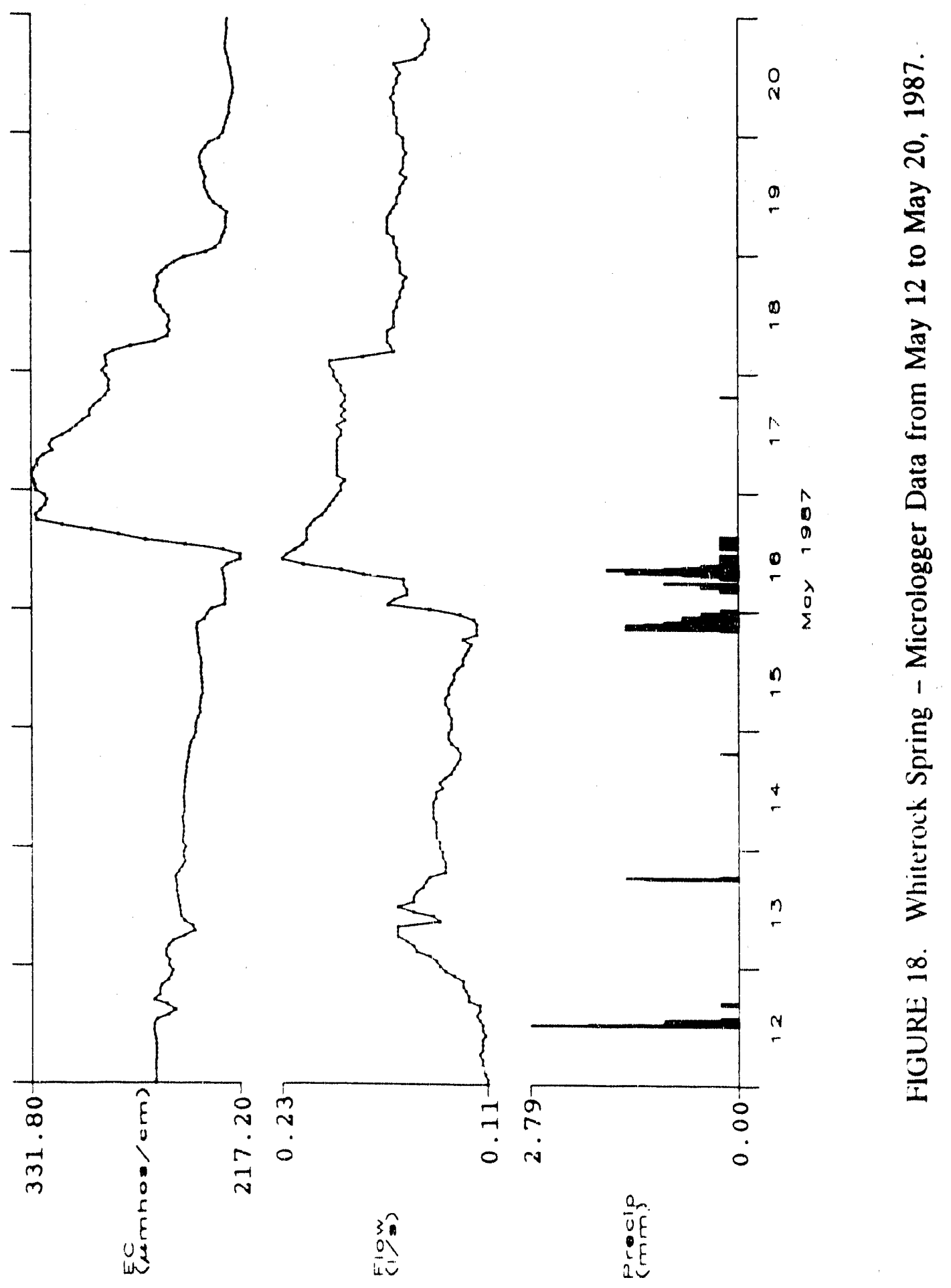


1100 hours, and ranged from 241 to $217 \mu$ mhos over 13 hours. In less than 8 hours (from 100 to 1800 hours), the EC increased $111 \mu$ mhos (from 217 to 328).

The second example occurred in July 1987 (Figure 19). A summary of the recorded precipitation during June is listed in Table 15. A stage and EC change was observed due to the precipitation event of July 20 to 21 and is shown in detail in Figure 20. Spring discharge responded about 1.5 hours after the onset of precipitation (July 20, 1125 hours). Peak flow occurred at 2100 hours and receded over a 24-hour period, with only one noticeable increase during this time frame. EC responded similarly to the first example by declining on July 20 from 1100 to 2300 hours ( 250 to $202 \mu$ mhos, respectively) then increasing to $335 \mu$ mhos in 16 hours (July 21, 1500 hours). Stage peaked approximately two hours before the rapid increase in EC.

\section{SUMMARY}

Temporal data were collected at Whiterock Spring from July 11, 1980 to January 20,1988 . During this data collection, the site was visited 63 times for routine measurements and sample collection. Data were collected from two discharge points at the site, Whiterock West (WRW) and Whiterock East (WRE). For the first several years of the study, a majority of the study effort was focused on WRW. Forty-eight samples ( 32 from WRW and 16 from WRE) were analyzed for major ionic composition. One-hundred-seventy-three environmental isotope samples were analyzed. During the period of record, the site was visited roughly every 40 days for approximately 7.5 years. The chemical composition of Whiterock Spring water is characterized as a sodium-bicarbonate-type water. WRW exhibited slightly more chemical variation than WRE (average less than 10 percent variation), even through WRW showed nearly three times more flow variation than WRE.

Temporal data were collected at two sample intervals, 40 days (low frequency) and one hour (high frequency). The low-frequency data were used to estimate long-

TABLE 15. SUMMARY OF PRECIPITATION AT WHITEROCK SPRING JULY' 1987.

\begin{tabular}{|c|c|c|c|c|}
\hline Date & $\begin{array}{c}\text { Minimum } \\
(\mathrm{cm})\end{array}$ & $\begin{array}{c}\text { Maximum } \\
(\mathrm{cm})\end{array}$ & $\begin{array}{l}\text { Sum } \\
(\mathrm{cm})\end{array}$ & $\begin{array}{l}\text { Duration } \\
\text { (minutes) }\end{array}$ \\
\hline July 16 & 0.03 & 0.03 & 0.03 & 15 \\
\hline July 20 & 0.03 & 0.13 & 3.89 & 735 \\
\hline \multirow[t]{2}{*}{ July 21} & 0.03 & 0.05 & 1.07 & 600 \\
\hline & 0.03 & 0.13 & 4.99 & 1.350 \\
\hline
\end{tabular}




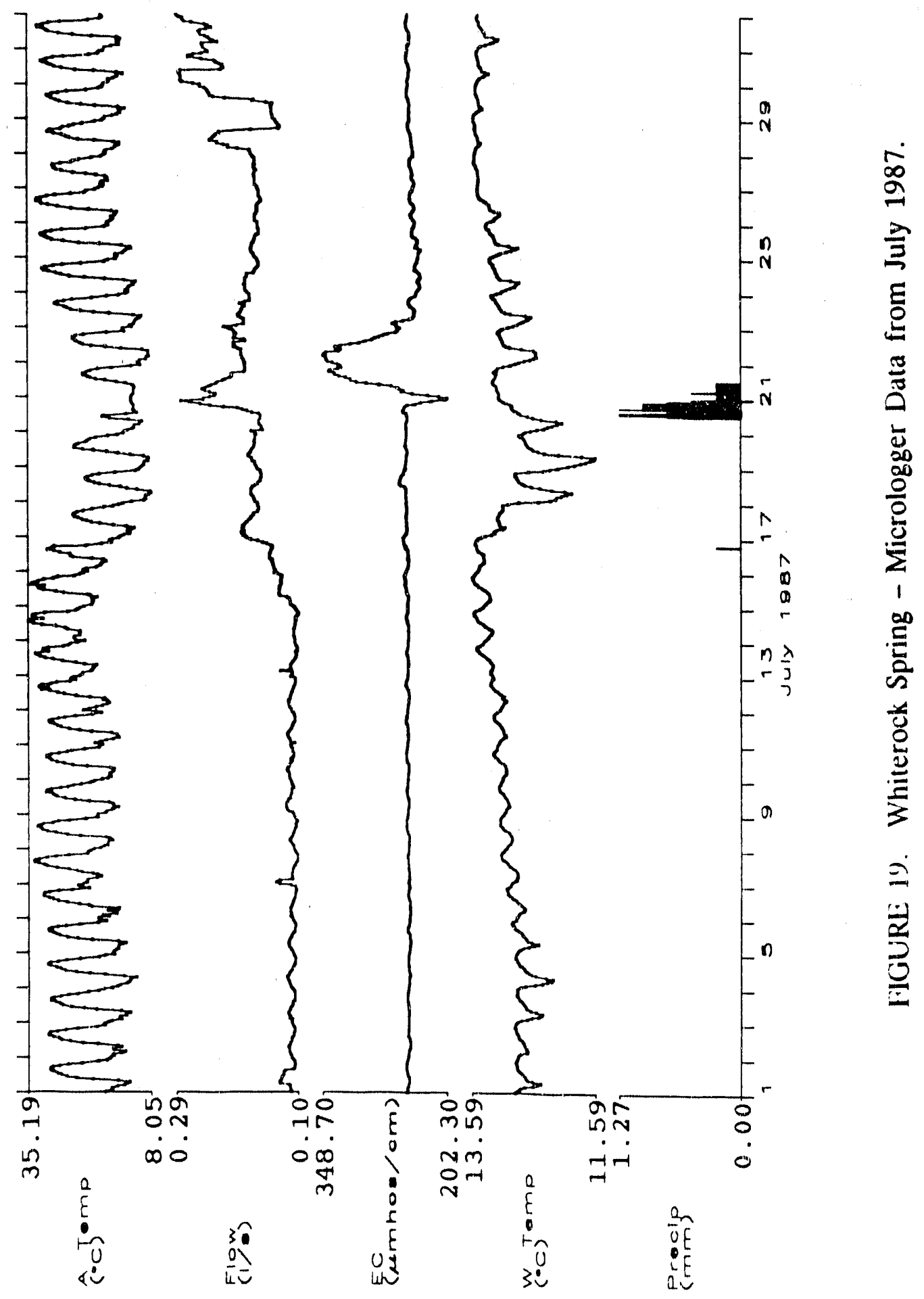




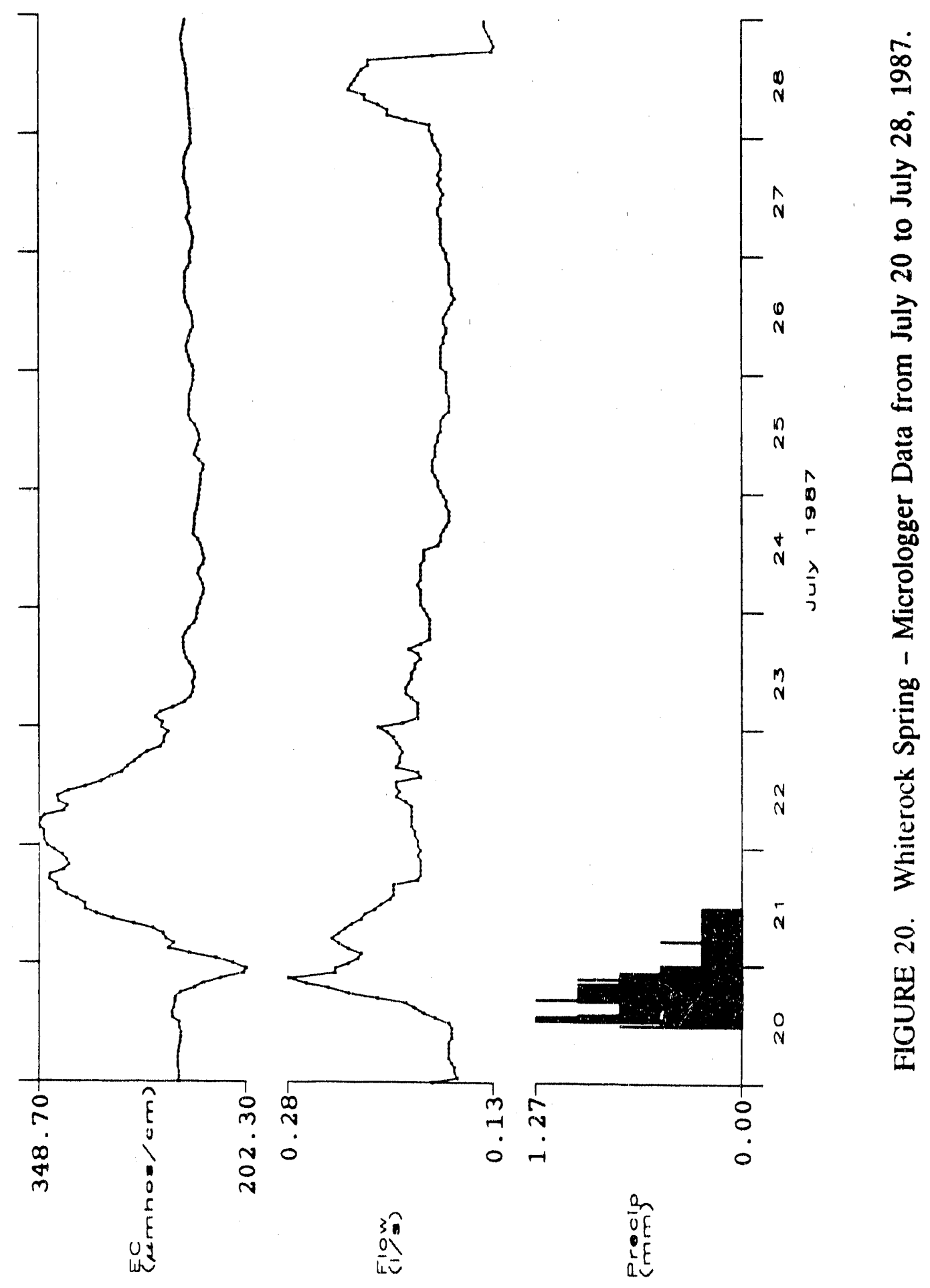


term variations in aquifer responses, such as seasonal variation, while the high-frequency data were used to estimate rapid responses, such as estimation of precipitation to discharge timing. Discharge from Whiterock Spring remained fairly constant during the study, with the exception of several extreme events.

Two significant precipitation events occurred in 1983. The first event was in February, while the second was in October. Discharge response to these precipitation events occurred almost immediately (less than 40 days) and based on the high frequency data collected in 1987, the pressure pulse probably came through only a few hours after major precipitation fell. In 1983, a broad-peaked increase in several cations and anions was observed 1.5 to 2 months after the pressure pulse. High frequency data suggests that $\mathrm{EC}$ fluctuates for several days following a precipitation event, responding within hours of the major precipitation. A $\delta^{18} \mathrm{O}$ isotopic variation of nearly $10 \%$ was also observed approximately 2.5 months after each of the 1983 storms. The minimum precipitation threshold is estimated from the limited extreme precipitation event data collected during micrologger monitoring. Two precipitation/ discharge examples were previously discussed in the micrologger statistics section (May 1987 and July 1987). Precipitation intensity/duration data suggest that only slight flow responses were discerned from May 9, $1987(0.10 \mathrm{~cm}$ over 30 minutes $)$ and May 1?. 1987 ( $0.30 \mathrm{~cm}$ over 45 minutes). Conversely, discernible flow responses could be attributed to May 7, 1987 ( $0.63 \mathrm{~cm}$ over 135 minutes) and May 12, 1987 $(0.89 \mathrm{~cm}$ over 135 minutes), and to two large extreme events on May $15-16(3.10 \mathrm{~cm}$ over 735 minutes) and July $20-21$ (4.96 cm over 1,335 minutes). Therefore, it is assumed that the minimum threshold is less than $0.63 \mathrm{~cm}$ over a 135 -minute duration and greater than $0.30 \mathrm{~cm}$ over a 45 -minute duration.

These observations suggest that 'Whiterock Spring discharge responds rapidly' to major precipitation events, and is presumably caused by pressure pulses transmitted through the aquifer. Such pressure pulses temporarily elevate water in the soil/rock above the equilibrium water table, allowing minerals to be dissolved. Equally, it takes approximately two months for Whiterock Spring to transmit water from the recharge area to the discharge point. Based on these temporal responses and from tritium collected at the springs, it is presumed that the aquifer is local to the Twin Peaks area. The hypothesized aquifer model will be further described in the discussion section. 


\section{CAPTAIN JACK SPRING}

\section{SETTING}

Captain Jack Spring is located at $37^{\circ} 10^{\prime} 06^{\prime \prime}$ N. latitude, $116^{\circ} 10^{\prime} 07^{\prime \prime}$ W. longitude at an elevation of $1,757 \mathrm{~m}(5,765 \mathrm{ft})$ in Area 12. The spring discharges on the east slope at the northern end of the Eleana Range, approximately $1.2 \mathrm{~km}$ east of Pahute Mesa Road via a game trail. Spring discharge collects in two small ponds which are watering holes for a small herd of wild horses.

The spring issues from the lower member of the Tertiary Indian Trails formation, near the contact between tuffs and the underlying Pennsylvanian Eleana formation. The tuff unit in this area is called the tuff at Captain Jack Spring, ranges from 90 to $120 \mathrm{~m}$ thick, and is composed of zeolitized bedded tuff (Gibbons et al., 1963). Locally, the Eleana formation is about $150 \mathrm{~m}$ thick and is composed of quartzite and minor sandstone ( 50 percent), argillite ( 35 percent), and conglomerate ( 15 percent).

A shallow synclinal feature is mapable in the tuffaceous rocks for approximately $4 \mathrm{~km}$ and plunges toward the southwest. Several small normal faults exist in the area, but do not appear to coincide with the discharge point of the spring.

The Indian Trails formation is characterized as a tuff aquitard, while the Eleana formation is characterized as the upper clastic aquitard. The interstitial permeability of the tuff members and transmissibility of the clastic rocks are considered negligible (Winograd and Thordarson, 1975). Based on this information, it is assumed that recharge water in the immediate vicinity of the spring flows through tuffaceous rocks along paths of primary and secondary permeability, and discharges from the zeolitized tuff along fractures and joints. The underlying low permeability clastic rocks may also influence the discharge characteristics of the area.

\section{GEOCHEMISTRY}

Captain Jack Spring water is characterized as a sodium-bicarbonate-type water. Seven samples were collected from Captain Jack Spring during the study period; the basic statistics for these aqueous species are listed in Table 16. The mean chemical composition of the water was run through the computer program WATEQDR to estimate chemical characteristics of the water. A summary of the results is listed in Table 17 . These results are similar to those computed for Whiterock Spring waters.

\section{TIME SERIES}

Only seven water samples were collected from Captain Jack Spring between March 18, 1981 and June 17, 1982 (Appendix C). Seasonal heating of the spring 
TABLE 16. CAPTAIN JACK ION CHEMISTRY SUMMARY STATISTICS FROM MARCH 1981 TO JUNE 1982.

\begin{tabular}{lcccccc}
\hline \multicolumn{1}{c}{ Variable } & Min. & Max. & Mean & SDEV & Coef. Var.** & $\mathrm{n}^{* * *}$ \\
\hline Temp. $\left({ }^{\circ} \mathrm{C}\right)$ & 5.0 & 17.8 & 11.4 & 4.9 & 43.0 & 10 \\
EC-lab* & 103.0 & 189.0 & 160.0 & 39.1 & 24.4 & 7 \\
$\mathrm{pH}-\mathrm{lab}$ & 7.08 & 7.64 & 7.32 & 0.19 & 2.6 & 7 \\
$\mathrm{Ca}(\mathrm{mg} / \mathrm{l})$ & 2.8 & 5.5 & 3.6 & 1.1 & 30.6 & 7 \\
$\mathrm{Mg}(\mathrm{mg} / \mathrm{l})$ & 0.4 & 1.7 & 0.9 & 0.5 & 55.6 & 7 \\
$\mathrm{Na}(\mathrm{mg} / \mathrm{l})$ & 19.3 & 40.5 & 32.4 & 9.4 & 29.0 & 7 \\
$\mathrm{~K}(\mathrm{mg} / \mathrm{l})$ & 1.34 & 3.66 & 2.53 & 0.95 & 37.5 & 7 \\
$\mathrm{Cl}(\mathrm{mg} / l)$ & 5.0 & 7.5 & 6.1 & 0.9 & 14.8 & 7 \\
$\mathrm{SO}_{4}(\mathrm{mg} / \mathrm{l})$ & 7.4 & 17.8 & 11.7 & 4.2 & 35.9 & 7 \\
$\mathrm{HCO}_{3}(\mathrm{mg} / l)$ & 34.6 & 102.0 & 77.6 & 30.4 & 39.2 & 7 \\
$\mathrm{SiO}_{2}(\mathrm{mg} / l)$ & 23.0 & 41.0 & 34.6 & 8.2 & 23.7 & 7 \\
$\mathrm{NO}_{3}(\mathrm{mg} / l)$ & 0.31 & 4.10 & 1.77 & 1.44 & 81.4 & 5 \\
\hline
\end{tabular}

* $\mu \mathrm{mhos} / \mathrm{cm} @ 25^{\circ} \mathrm{C}$

* SDEV/mean x 100

** Number of observations

TABLE 17. SUMMARY OF RESULTS FROM WATEQDR FOR MEAN CAPTAIN JACK CHEMISTRY.

\begin{tabular}{lcll}
\hline \multicolumn{2}{c}{ Physical Parameter } & \multicolumn{1}{c}{ log - Saturation Index } \\
\hline $\mathrm{pH}$-lab & 7.32 & Anhydrite & -3.64 \\
Temperature & $11.4^{\circ} \mathrm{C}$ & Calcite & -1.80 \\
$\log \mathrm{PCO}_{2}$ & -2.50 & Dolomite & -4.07 \\
& & G'nsum & -3.53 \\
\hline
\end{tabular}

water is coincident with other springs in the study; the water temperature ranged nearly $13^{\circ}$ from winter to summer. The maximum temperature observed was in June. A deflection in the trend of several ionic constituents was observed in May 1981, including increases in calcium, magnesium, sodium, potassium, chloride, sulfate, bicarbonate, and silica ions. This may have been the result of seasonal snowmelt in the Eleana Range. However, it should be noted that the range observed between each ionic species is small, very close to the measurement and possible sam- 
pling errors associated with these species. Other variations may be accounted for due to the low discharge from this spring, thereby increasing the possibility of evaporation complexities.

During this same time period, several environmental isotope samples were collected (Appendix D). Three hydrogen isotope samples showed a range of $14 \%$ $(-101 \%$ to $-115 \%$, while eight oxygen isotope samples showed a range of $2.9 \%$ $(-11.8 \%$ oo to $-14.7 \%$ \%o $)$. No noticeable trends were observed between these isotopes as a function of time. Three tritium samples were collected (one unenriched and two enriched). The tritium samples ranged from 118 to $234 \mathrm{pCi} / l$ from samples taken approximately one year apart. These data suggest the spring water may be composed of recharge close to the spring. These data further suggest the spring water may be influenced periodically by rainfall/runoff events. 


\section{TOPOPAH SPRING}

\section{SETTING}

Topopah Spring is located at $36^{\circ} 56^{\prime} 17^{\prime \prime} \mathrm{N}$. latitude, $116^{\circ} 16^{\prime} 15^{\prime \prime} \mathrm{W}$. longitude at an elevation of $1,737 \mathrm{~m}(5,700 \mathrm{ft})$ in Area 29 . The spring lies high on the southwest flank of Shoshone Peak, approximately $5 \mathrm{~km}$ north of the Shoshone Mountain Road Mine Mountain Road intersection. The discharge area is made up of four to five springs and numerous seeps.

The springs issue from the Tertiary Rhyolite of Calico Hills formation and, more specifically, from the bedded tuff and rhyolite flow members. Both members each range from 0 to $400 \mathrm{~m}$ thick in the area and have been described by Orkild and O'Connor (1970) as follows: flows of vitrophyric to devitrified lava and flow-banded spherulitic rhyolite with sparse phenocrysts of quartz, alkali feldspar, plagioclase, and biotite; and poorly to well-sorted, zeolitized, cross-bedded tuff that contains abundant lithic inclusions, tuffaceous sandstone, large blocks of vesiculated glass in a matrix of shards and pumice, and abundant inclusions of rhyolite and welded tuff. Many other Tertiary volcanic rocks occur in close proximity to the spring.

The structural geology near the spring is dominated by normal faults; the most prominent fault trends north-south approximately $4 \mathrm{~km}$ west of the spring and about $6 \mathrm{~km}$ to the north. This feature bounds the volcanic block to the west and is approximately $0.2 \mathrm{~km}$ from the discharge area. Vertical joint sets have been mapped in the discharge area. Numerous other faults exist in the area and exhibit much less displacement than the previously described fault.

All known springs and seeps in the area discharge from the rhyolite of Calico Hills formation. This formation is characterized as a tuff aquitard. The regional permeability of this hydrostratigraphic unit is considered negligible (Winograd and Thordarson, 1975). It is assumed that locally derived recharge water from Shoshune Peak flows through the tuffaceous rock, discharging at the fault intersection via primary and secondary permeability paths.

\section{GEOCHEMISTRY}

Topopah Spring water is characterized as a sodium-calcium-bicarbonate-type water. Six samples were collected from Topopah Spring during the study period; the basic statistics for these aqueous species are listed in Table 18. The mean chemical composition of the water was run through the computer program WATEQDR to estimate chemical characteristics of the water. A summary of the results are listed in Table 19. These results are similar to those computed for Cane Spring waters. 
TABLE 18. TOPOPAH SPRING ION CHEMISTRY SUMMARY STATISTICS FROM MARCH 1981 TO JUNE 1982.

\begin{tabular}{lcccccc}
\hline \multicolumn{1}{c}{ Variable } & Min. & Max. & Mean & SDEV & Coef. Var. ** & $\mathrm{n}^{* * *}$ \\
\hline Temp. $\left({ }^{\circ} \mathrm{C}\right)$ & 5.0 & 28.5 & 14.7 & 8.0 & 54.4 & 9 \\
$\mathrm{EC}-\mathrm{lab} \mathrm{ab}^{*}$ & 96.0 & 119.0 & 110.8 & 8.1 & 7.3 & 6 \\
$\mathrm{pH}-\mathrm{lab}$ & 6.89 & 7.55 & 7.09 & 0.25 & 3.5 & 6 \\
$\mathrm{Ca}(\mathrm{mg} / \mathrm{l})$ & 6.0 & 7.2 & 6.7 & 0.4 & 6.0 & 6 \\
$\mathrm{Mg}(\mathrm{mg} / l)$ & 1.3 & 1.6 & 1.4 & 0.1 & 7.1 & 6 \\
$\mathrm{Na}(\mathrm{mg} / l)$ & 9.4 & 12.8 & 11.4 & 1.2 & 10.5 & 6 \\
$\mathrm{~K}(\mathrm{mg} / \mathrm{l})$ & 4.50 & 6.99 & 6.01 & 0.87 & 14.5 & 6 \\
$\mathrm{Cl}(\mathrm{mg} / l)$ & 1.6 & 4.7 & 2.9 & 1.2 & 41.4 & 6 \\
$\mathrm{SO}_{4}(\mathrm{mg} / l)$ & 6.6 & 10.8 & 8.1 & 1.6 & 19.8 & 6 \\
$\mathrm{HCO}_{3}(\mathrm{mg} / l)$ & 34.6 & 58.0 & 52.0 & 9.0 & 17.3 & 6 \\
$\mathrm{SiO}_{2}(\mathrm{mg} / l)$ & 25.0 & 60.0 & 48.7 & 13.3 & 27.3 & 6 \\
$\mathrm{NO}_{3}(\mathrm{mg} / l)$ & 0.31 & 5.10 & 1.89 & 2.23 & 118.0 & 4 \\
\hline
\end{tabular}

* $\mu \mathrm{mhos} / \mathrm{cm} @ 25^{\circ} \mathrm{C}$

* SDEV/mean x 100

*** Number of observations

TABLE 19. SUMMARY OF RESULTS FROM WATEQDR FOR MEAN TOPOPAH SPRING CHEMISTRY.

\begin{tabular}{lcll}
\hline \multicolumn{2}{c}{ Physical Parameter } & \multicolumn{2}{c}{ log - Saturation Index } \\
\hline pH-lab & 7.09 & Anhydrite & -3.48 \\
Temperature & $14.7^{\circ} \mathrm{C}$ & Calcite & -1.87 \\
$\log \mathrm{PCO}_{2}$ & -2.42 & Dolornite & -4.25 \\
& & Gypsum & -3.41 \\
\hline
\end{tabular}

\section{TIME SERIES}

Only six water samples were collected from Topopah Spring between March 19 , 1981 and June 17, 1982 (Appendix C). Seasonal heating of the spring water is coincident with other springs in the study; the water temperature ranged nearly $13.5^{\circ}$ from winter to summer. The maximum temperature observed was in June. A deflection in the trend of several ionic constituents was observed during the winter low tempera- 
tures of February through March 1982, including decreases in calcium, magnesium, sodium, potassium, and bicarbonate ions. An increase in sulfate was observed at this same point in the record. During the period of record, sulfate was inversely correlated with bicarbonate ion with an $\mathrm{R}^{2}$ of 92 percent. However, it should be noted that the range observed between each ionic species is small, very close to the measurement and possible sampling errors associated with these species.

During this same time period, several environmental isotope samples were collected (Appendix D). Only one hydrogen isotope sample was collected $(-88 \%$ ), however, nine oxygen isotope samples showed a range of $1.9 \%$ oo $(-11.0 \%$ oo to $-12.9 \%$ ). No noticeable trends were observed between these isotopes as a function of time. Three tritium samples were collected (one unenriched and two enriched). The unenriched sample was below the detection limit $(<160 \mathrm{pCi} / l)$. However, samples collected in April 1981 and March 1982 showed 83 and $64 \mathrm{pCi} / l$, respectively. These data suggest the spring water is predominantly from local recharge and is relatively young. 


\section{TIPPIPAH SPRING}

\section{SETTING}

Tippipah Spring is located at $37^{\circ} 02^{\prime} 35^{\prime \prime} \mathrm{N}$. latitude, $116^{\circ} 12^{\prime} 12^{\prime \prime} \mathrm{W}$. longitude at an elevation of $1,585 \mathrm{~m}(5,200 \mathrm{ft})$ in Area 16. The spring issues from an adit on the northeast slope of Shoshone Mountain approximately $3 \mathrm{~km}$ west of the Buckboard Mesa Road - Pahute Mesa Road south intersection. Spring discharge is impounded in the adit by a debris pile; discharge measurements are, therefore, relative, made with a staff gauge driven into the adit floor.

The spring issues from the Tertiary Indian Trail formation, near the contact between tuff units and the underlying Pennsylvanian Eleana formation (quartzite, limestone, and conglomerate). The tuff unit ranges from 180 to $340 \mathrm{~m}$ thick and was described by Orkild (1963) as follows: lenticular, non-welded ash-flow and ash-fall tuffs; zeolitic and locally siliceous; and local basal breccia of paleozoic rocks.

The most prominent structural geologic feature in the area is a syncline in the Pennsylvanian/Permian Tippipah limestone. The syncline axis trends northeast, is mapable over a distance of approximately $10 \mathrm{~km}$ (along Syncline Ridge), and is approximately $1 \mathrm{~km}$ southeast of Tippipah Spring. The spring discharges from the upthrown block of a north-northwest trending normal fault which extends approximately $0.5 \mathrm{~km}$ south and $4 \mathrm{~km}$ north of the spring. Several other less apparent normal faults also exist within the area. Many are associated with the synclinal feature.

The Indian Trails formation is characterized as a tuff aquitard, while the Eleana formation is characterized as the upper clastic aquitard. These aquitards (as hydrostratigraphic units) are considered relatively impermeable (Winograd and Thordarson, 1975). However, vertical joint sets were mapped in close proximity to the spring, suggesting local, increased, secondary permeability near the discharge point. Based on this information, it is assumed that recharge water from northern Shoshone Mountain flows through tuffaceous rocks along paths of primary and secondary permeability, and discharges from the tuff along a faulted contact between the tuff and the underlying clastic rocks (Eleana formation).

\section{GEOCHEMISTRY}

Tippipah Spring water is characterized as a sodium-bicarbonate-type water. Five samples were collected from Tippipah Spring during the study period; the basic statistics for these aqueous species are listed in Table 20. The mean chemical composition of the water was run through the computer program WATEQDR to estimate chemical characteristics of the water. A summary of the results is listed in Table 21. 
TABLE 20. TIPPIPAH SPRING ION CHEMISTRY SUMMARY STATISTICS FROM JULY 1980 TO APRIL 1982.

\begin{tabular}{lccccrc}
\hline \multicolumn{1}{c}{ Variable } & Min. & Max. & Mean & SDEV & Coef. Var.** $n^{* * *}$ \\
\hline Temp. $\left({ }^{\circ} \mathrm{C}\right)$ & 3.0 & 14.5 & 11.0 & 3.7 & 33.6 & 8 \\
EC-lab* & 178.0 & 212.0 & 203.2 & 14.2 & 7.0 & 5 \\
$\mathrm{pH}-\mathrm{lab}$ & 7.24 & 7.46 & 7.31 & 0.09 & 1.2 & 5 \\
$\mathrm{Ca}(\mathrm{mg} / \mathrm{l})$ & 4.3 & 6.6 & 5.3 & 0.9 & 17.0 & 5 \\
$\mathrm{Mg}(\mathrm{mg} / \mathrm{l})$ & 0.5 & 0.8 & 0.7 & 0.1 & 14.3 & 5 \\
$\mathrm{Na}(\mathrm{mg} / l)$ & 34.5 & 40.4 & 38.2 & 2.3 & 6.0 & 5 \\
$\mathrm{~K}(\mathrm{mg} / \mathrm{l})$ & 2.70 & 3.48 & 3.02 & 0.35 & 11.6 & 5 \\
$\mathrm{Cl}(\mathrm{mg} / \mathrm{l})$ & 6.3 & 8.4 & 7.6 & 0.8 & 10.5 & 5 \\
$\mathrm{SO}_{4}(\mathrm{mg} / l)$ & 14.4 & 23.9 & 17.9 & 3.6 & 20.1 & 5 \\
$\mathrm{HCO}_{3}(\mathrm{mg} / l)$ & 76.2 & 93.1 & 87.8 & 6.7 & 7.6 & 5 \\
$\mathrm{SiO}_{2}(\mathrm{mg} / l)$ & 50.0 & 51.0 & 50.8 & 0.4 & 0.8 & 5 \\
$\mathrm{NO}_{3}(\mathrm{mg} / \mathrm{l})$ & 5.36 & 9.30 & 6.54 & 1.85 & 28.3 & 4 \\
\hline
\end{tabular}

* $\mu \mathrm{mhos} / \mathrm{cm} @ 25^{\circ} \mathrm{C}$

* SDEV/mean x 100

*** Number of observations

TABLE 21. SUMMARY' OF RESULTS FROM WATEQDR FOR MEAN TIPPIPAH SPRING CHEMISTRY.

\begin{tabular}{lclc}
\hline \multicolumn{2}{c}{ Physical Parameter } & \multicolumn{1}{c}{ Ing - Saturation Index } \\
\hline pH-lab & 7.31 & Anhydrite & -3.31 \\
Temperature & $11.0^{\circ} \mathrm{C}$ & Calcite & -1.61 \\
$\log \mathrm{PCO}_{2}$ & -2.44 & Dolomite & -3.97 \\
& & Gypsum & -3.20 \\
\hline
\end{tabular}

\section{TIME SERIES}

Only five water samples were collected from Tippipah Spring between July 11 , 1980 and April 30, 1982 (Appendix C). Seasonal heating of the spring water is coincident with other springs in the study; the water temperature ranged nearly $11.5^{\circ}$ from winter to summer. The maximum temperature observed was in July. A deflection in the trend of several ionic constituents was observed in October 1981, including increases in calcium, magnesium, sodium, chloride, sulfate, and bicarbonate 
ions. A slight decrease in potassium was observed at this same point in the record and silica remained constant during the study. However, it should be noted that the range observed between each ionic species is small, very close to the measurement and possible sampling errors associated with these species.

During this same time period, several environmental isotope samples were collected (Appendix D). Two hydrogen isotope samples showed a range of $7 \%(-91 \%$ to $-98 \%$ ), while six oxygen isotope samples showed a range of $2.6 \%(-10.6 \%$ o to $-13.2 \%$. . No noticeable trends were observed between these isotopes as a function of time. Three tritium samples were collected (one unenriched and two enriched). The unenriched sample was below the detection limit $(<160 \mathrm{pCi} / l)$. However, samples collected in April 1981 and March 1982 showed 44.8 and $54.4 \mathrm{pCi} / l$, respectiveiy. These data suggest the spring water is predominantly from local recharge and is relatively young. 


\section{OAK SPRING}

\section{SETTING}

Oak Spring is located at $37^{\circ} 14^{\prime} 45^{\prime \prime} \mathrm{N}$. latitude, $116^{\circ} 04^{\prime} 30^{\prime \prime} \mathrm{W}$. longitude at an elevation of $1,786 \mathrm{~m}(5,860 \mathrm{ft})$ in Area 15 , approximately $7 \mathrm{~km}$ northwest of Groom Lake Road. The discharge point has been developed with a pipe at the southwest flank of Oak Spring Butte. There are several other small springs and seeps in this general area.

The spring issues from the Tertiary Indian Spring formation, near the contact of the zeolitized tuff member of this formation and the underlying Pennsylvanian Eleana formation rocks (quartzite, conglomerate, and argillite). The zeolitized tuff ranges from 75 to $300 \mathrm{~m}$ thick and has been described by Barnes et al. (1963) as follows: non-welded, white to yellowish and pinkish grey; chiefly non-bedded; locally may include vesicular devitrified ash-flow tuff with abundant quartz and feld. spar phenocrysts. A granitic stock (commonly referred to as climax stock) crops out approximately $1 \mathrm{~km}$ southeast of the spring and is composed of quartz monzonite and granodiorite stocks and sills.

The structural geology near the spring is dominated by normal faults in the clastic rocks, as well as a north-south-trending fault (Tippinip Fault) extending through the tuffaceous rock approximately $0.4 \mathrm{~km}$ east of the spring. With the exception of some overturned beds near the Tippinip Fault, most beds in the clastic rocks dip toward the southeast and most beds in the tuffs dip northerly near the spring.

All known springs and seeps in the area discharge from the zeolitized tuff unit of the Indian Trails formation. The Indian Trails formation is characterized as a tuff aquitard, while the Eleana formation is characterized as the upper clastic aquitard. The interstitial permeability of the tuff members and transmissibility of the clastic rocks are considered negligible, however, the Tub Springs and Grouse Canyon members of the Indian Trails formation (overlying the zeolitized member) are locally considered aquifers near the Oak Spring discharge area (Winograd and Thordarson, 1975). Based on this information, it is assumed that recharge water from the belted range and vicinity flows through the tuffaceous rocks along paths of primary and secondary permeability, and discharges from the zeolitized tuff member at a lower permeability zone in the tuff. The underlying low permeability clastic rocks may also influence the discharge characteristics of the area.

\section{GEOCHEMISTRY}

Oak Spring water is characterized as a sodium-calcium-bicarbonate-type water. Five samples were collected from Oak Spring during the study period: the 
basic statistics for these aqueous species are listed in Table 22. The mean chemical composition of the water was run through the computer program WATEQDR to estimate chemical characteristics of the water. A summary of the results is listed in Table 23. These results match closely with those computed for Cane Spring waters.

TABLE 22. OAK SPRING ION CHEMISTRY SUMMARY STATISTICS FROM JANUARY 1981 TO APRIL 1982.

\begin{tabular}{|c|c|c|c|c|c|c|}
\hline Variable & Min. & Max. & Mean & SDEV & Coef. Var.** & $\mathrm{n}^{* * *}$ \\
\hline Temp. $\left({ }^{\circ} \mathrm{C}\right)$ & 10.0 & 17.7 & 14.0 & 2.4 & 17.1 & 8 \\
\hline EC-lab* & 222.0 & 236.0 & 228.4 & 5.5 & 2.4 & 5 \\
\hline $\mathrm{pH}-\mathrm{lab}$ & 7.20 & 7.67 & 7.39 & 0.18 & 2.4 & 5 \\
\hline $\mathrm{Ca}(\mathrm{mg} / \mathrm{l})$ & 17.4 & 18.8 & 17.8 & 0.6 & 3.4 & 5 \\
\hline $\mathrm{Mg}(\mathrm{mg} / l)$ & 4.2 & 4.6 & 4.4 & 0.2 & 4.5 & 5 \\
\hline $\mathrm{Na}(\mathrm{mg} / \mathrm{l})$ & 19.6 & 21.4 & 20.6 & 0.8 & 3.9 & 5 \\
\hline $\mathrm{K}(\mathrm{mg} / l)$ & 6.00 & 6.27 & 6.16 & 0.14 & 2.3 & 5 \\
\hline $\mathrm{Cl}(\mathrm{mg} / \mathrm{l})$ & 8.7 & 10.3 & 9.2 & 0.7 & 7.6 & 5 \\
\hline $\mathrm{SO}_{4}(\mathrm{mg} / l)$ & 9.6 & 12.6 & 10.5 & 1.2 & 11.4 & 5 \\
\hline $\mathrm{HCO}_{3}(\mathrm{mg} / \mathrm{l})$ & 111.0 & 115.0 & 113.2 & 1.6 & 1.4 & 5 \\
\hline $\mathrm{SiO}_{2}(\mathrm{mg} / \mathrm{l})$ & 56.0 & 58.0 & 56.6 & 0.9 & 1.6 & 5 \\
\hline $\mathrm{NO}_{3}(\mathrm{mg} / \mathrm{l})$ & 0.62 & 5.50 & 2.38 & 2.71 & 113.9 & 3 \\
\hline \multicolumn{7}{|c|}{$\begin{array}{l}* \quad \mu \text { mhos } / \mathrm{cm} @ 25^{\circ} \mathrm{C} \\
* * \quad \mathrm{SDEV} / \mathrm{mean} \times 100 \\
* * * \text { Number of observations }\end{array}$} \\
\hline \multicolumn{7}{|c|}{$\begin{array}{ll}\text { TABLE 23. } & \text { SUMMARY OF RESULTS FROM WATEQDR FOR MEAN OAK } \\
& \text { SPRING CHEMISTRY. }\end{array}$} \\
\hline \multicolumn{3}{|c|}{ Physical Parameter } & \multicolumn{4}{|c|}{ log - Saturation Index } \\
\hline $\mathrm{pH}-\mathrm{lab}$ & \multicolumn{2}{|c|}{7.39} & \multicolumn{2}{|c|}{ Anhydrite } & \multicolumn{2}{|l|}{-3.03} \\
\hline \multicolumn{2}{|c|}{ Temperature } & $14.0^{\circ} \mathrm{C}$ & \multicolumn{2}{|c|}{ Calcite } & \multicolumn{2}{|l|}{-0.86} \\
\hline \multirow[t]{2}{*}{$\log \mathrm{PCO}_{2}$} & \multirow{2}{*}{\multicolumn{2}{|c|}{-2.40}} & \multicolumn{2}{|c|}{ Dolomite } & \multicolumn{2}{|l|}{-2.17} \\
\hline & & & \multicolumn{2}{|c|}{ Gypsum } & \multicolumn{2}{|l|}{-2.95} \\
\hline
\end{tabular}




\section{TIME SERIES}

Only five water samples were collected from Oak Spring between January 14, 1981 and April 29, 1982 (Appendix C). Seasonal heating of the spring water is coincident with other springs in the study; the water temperature ranged nearly $8^{\circ}$ from winter to summer. The maximum temperature observed was in June. At this same sample point, a deflection in the trend of several ionic constituents was observed including decreases in calcium, magnesium, sodium, chloride, and bicarbonate ions. A slight increase in sulfate was observed at this same point in the record and a silica decrease about two months earlier. However, it should be noted that the range observed between each ionic species is small, very close to the measurement and possible sampling errors associated with these species.

During this same time period, several environmental isotope samples were collected (Appendix D). Two hydrogen isotope samples showed a range of $10 \%$ $(-96 \%$ to $-106 \%$, while five oxygen isotope samples showed a range of $0.8 \%$ $(-12.2 \%$ to $-13.0 \%$ oo $)$ No noticeable trends were observed between these isotopes as a function of time. Three tritium samples were collected (one unenriched and two enriched). The unenriched sample and one enriched sample were below the detection limits ( $<160 \mathrm{pCi} / l$ and $<16 \mathrm{pCi} / l$, respectively). However, a sample collected in March 1982 showed $67 \mathrm{pCi} / l$. The two enriched samples were collected approximately one year apart (April $1981=<16$ and March $1982=67$ ). These data suggest the spring water may be influenced periodically by rainfall/runoff events. Therefore, the water age cannot be thoroughly understood, but may be as old as 30 years. 


\section{DISCUSSION}

Individual spring characteristics and temporal variations have been discussed in previous sections. Intraspring comparisons will be discussed here, including: similarities, differences, and temporal variations.

The six springs from this study all issue from Miocene (12 to 25 million years old) volcanic rocks. The four springs at the northern end of the study area (Oak, Whiterock, Captain Jack, and Tippipah) issue from the same formation, the Indian Trails formation, while Topopah Spring issues from the rhyolite of Calico Hills formation and Cane Spring issues from the Wahmonie and Salyer formations (Table 24). Lithologic variations in the various formations produce the different type waters observed. Generally, water discharging from the Indian Trails formation is characterized as a sodium-bicarbonate-type water, while water from the southern portion of the study area contains higher concentrations of calcium and is characterized as a sodium-calcium-bicarbonate water. The average chemical composition of all six springs are plotted in a Durov diagram and distinctly shows these two groupings (Figure 21). All of the springs have been categorized together as a sodium-potassium-bicarbonate hydrochemical facies by Winograd and Thordarson (1975). The aforementioned study also suggests that these formations are aquitards of very low interstitial permeability and transmissivity. Previous geologic studies have identified faults and fractures near each of the springs; therefore, it is assumed that groundwater is being transmitted via avenues of secondary permeability. The lateral extent and interconnectedness of these fractures and joints are difficult to estimate.

High spatial variability exists in precipitation across the NTS, due in part to local orographic effects. A positive linear correlation exists between elevation and mean precipitation (French, 1986, pp. 19-35). Annual precipitation ranges from $15.8 \mathrm{~cm}$ at

TABLE 24. SPRING DISCHARGE CHARACTERISTICS FOR SELECTED SPRINGS ON THE NTS.

\begin{tabular}{llll}
\hline Site Name & \multicolumn{1}{c}{ Formation } & Age & Type Water \\
\hline Cane & Wahmonie \& Salyer & Miocene & $\mathrm{Na}-\mathrm{Ca}-\mathrm{HCO}_{3}$ \\
Whiterock & Indian Trails & Miocene & $\mathrm{Na}-\mathrm{HCO}_{3}$ \\
Captain Jack & Indian Trails & Miocene & $\mathrm{Na}-\mathrm{HCO}_{3}$ \\
Topopah & Rhyolite of Calico Hills & Miocene & $\mathrm{Na}-\mathrm{Ca}-\mathrm{HCO}_{3}$ \\
Tippipah & Indian Trails & Miocene & $\mathrm{Na}-\mathrm{HCO}_{3}$ \\
Oak & Indian Trails & Miocene & $\mathrm{Na}-\mathrm{Ca}-\mathrm{HCO}_{3}$ \\
\hline
\end{tabular}




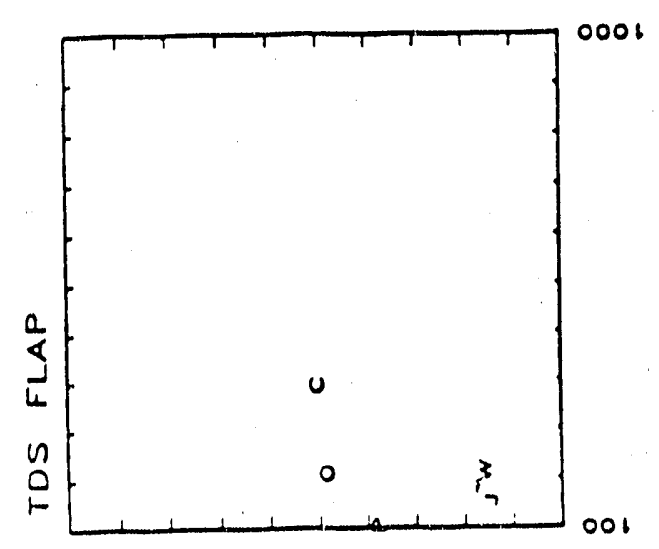

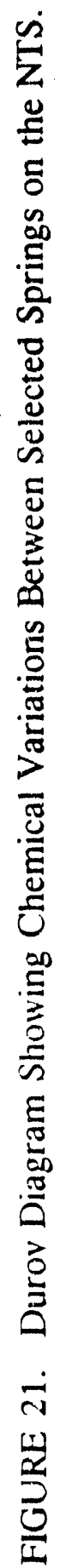


Desert Rock to $29.5 \mathrm{~cm}$ at Rainier Mesa $(1,005 \mathrm{~m}$ and 2,283 $\mathrm{m}$ above sea level, respectively). No known studies have been conducted to evaluate/model spatial and temporal variation with respect to different storm-tracks. However, a high correlation was observed between the two precipitation stations used in this study (Station $\# 76$ - Cane Spring and Station \#34 - Area 12 Mesa), related to the relative mass of the precipitation events. Summer precipitation (May, June, July, August, and September) showed a correlation of 0.85 , while winter showed a less significant correlation of 0.57 (Figure 22).

Environmental isotope analyses from precipitation show seasonal variations, enrichment during the summer and depletion in the winter (Ingraham et al., 1990). This is generally believed to be the result of warm southerly storm-tracks in the summer, producing convective-type storms, compared to cooler northerly stormtracks in the winter, producing snow and rain showers. Oxygen and hydrogen isotope samples from the six springs in this study are highly variable, both spatially and temporally. This variation can be observed in Figure 23a, with values for Cane and Whiterock Springs averaged. Numerous samples from Cane and Whiterock Springs are plotted on Figure 23b and show a great deal of variation about their means as plotted on Figure 23a. Discharge water isotope variations such as this are presumably the result of precipitation/input variations, rather than isotopic fractionation.

The oxygen isotope composition of precipitation at Site ST 4 was $-0.70 \%$ in August 1983, as previously described. The resulting isotopic pulse was observed at Cane Spring in October 1983 and had an oxygen composition of $-7.10 \%$, nearly 65 percent difference from the mean oxygen composition at Cane Spring $(-10.9 \%$ note: the extreme event was filtered from this mean). The groundwater age at Cane Spring is 30 to 600 years old, yet a distinct pulse migrated through the aquifer in approximately two months. A similar isotopic discharge response was observed at Whiterock Spring in October 1983 and exhibited approximately 80 percent enrichment above the mean spring composition. The groundwater age at Whiterock Spring is approximately 25 to 30 years old. Based on these phenomena, it is theorized that recharge waters derived from extreme precipitation events do not thoroughly mix with reservoir waters prior to discharge. An intercomparison of precipitation, discharge, and $\delta^{18} \mathrm{O}$ between Cane and Whiterock Springs is presented in Figure 24. The $y$ sub-axis range for precipitation and $\delta^{18} \mathrm{O}$ is preset to the observed minimum and maximum at both sites, respectively. However, due to the large difference in discharge between sites, the y sub-axis range for discharge was set to the individual site's minimum and maximum.

The October 1983 flow response was more prominent at Cane Spring than at Whiterock Spring, but both springs responded in less than 40 day's (one sample inter- 


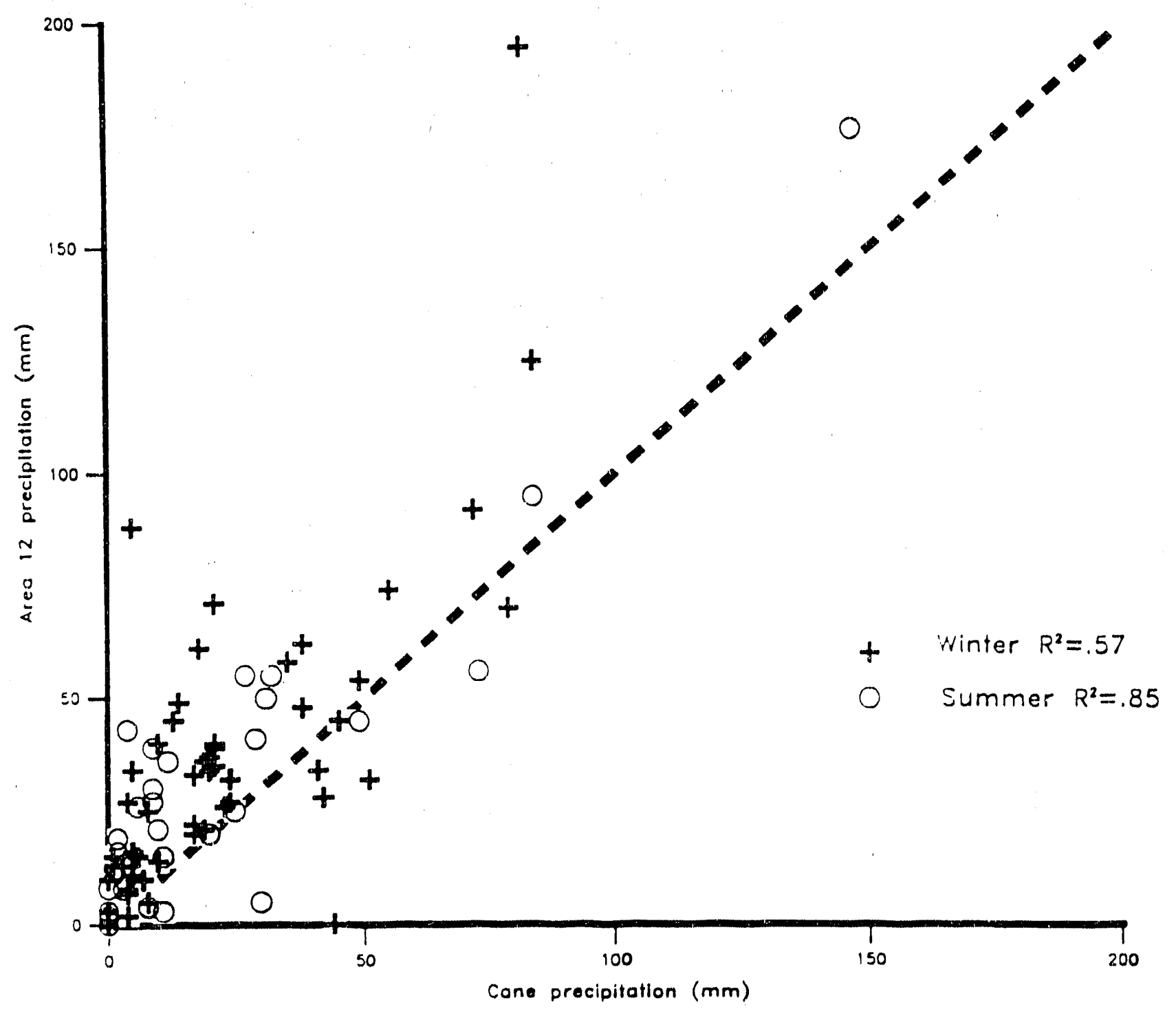

FIGURE 22. Winter and Summer Precipitation - Cane versus Area 12 Mesa. 


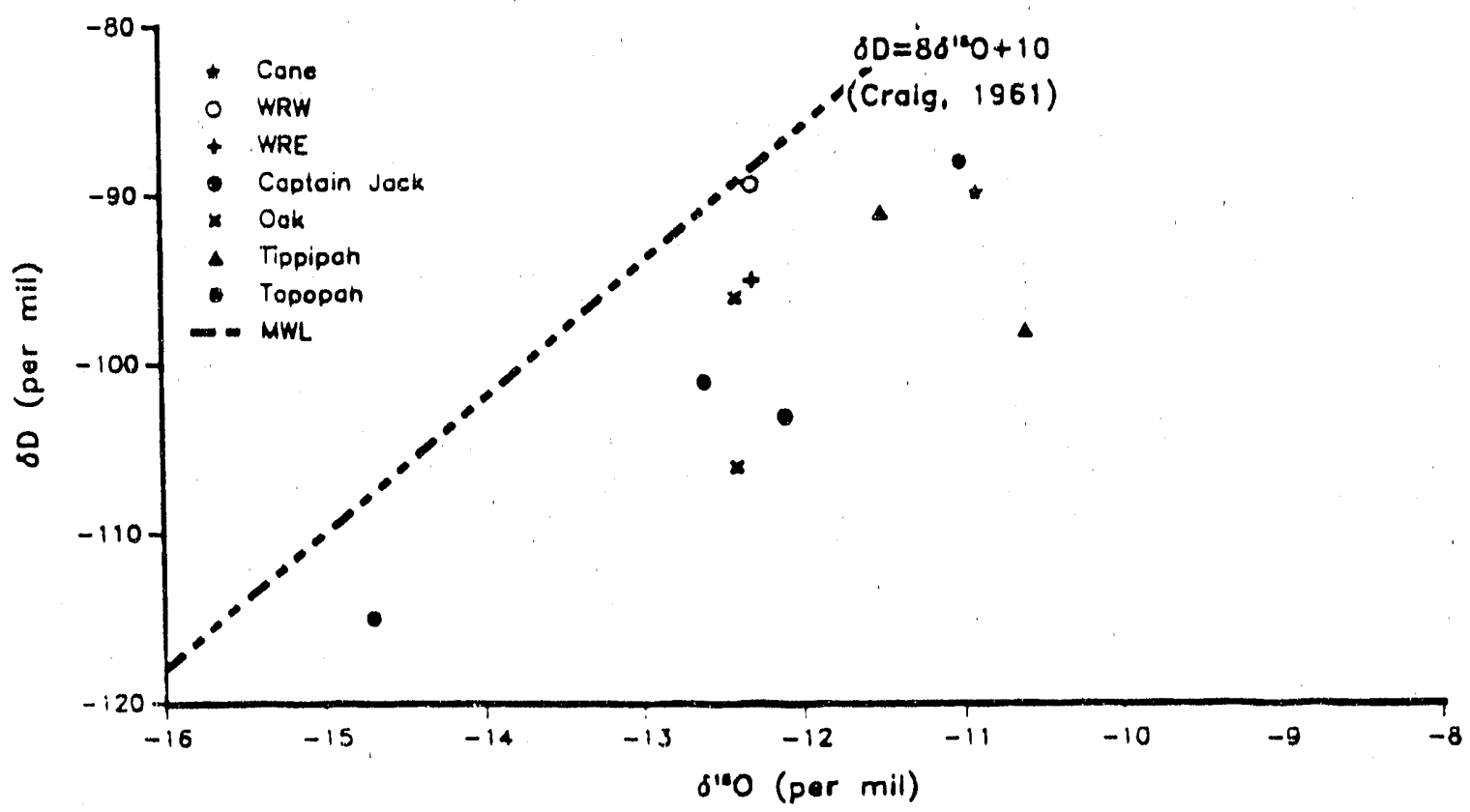

FIGURE 23a. $\delta D$ versus $\delta^{18} \mathrm{O}$ for Selected Springs on the NTS.

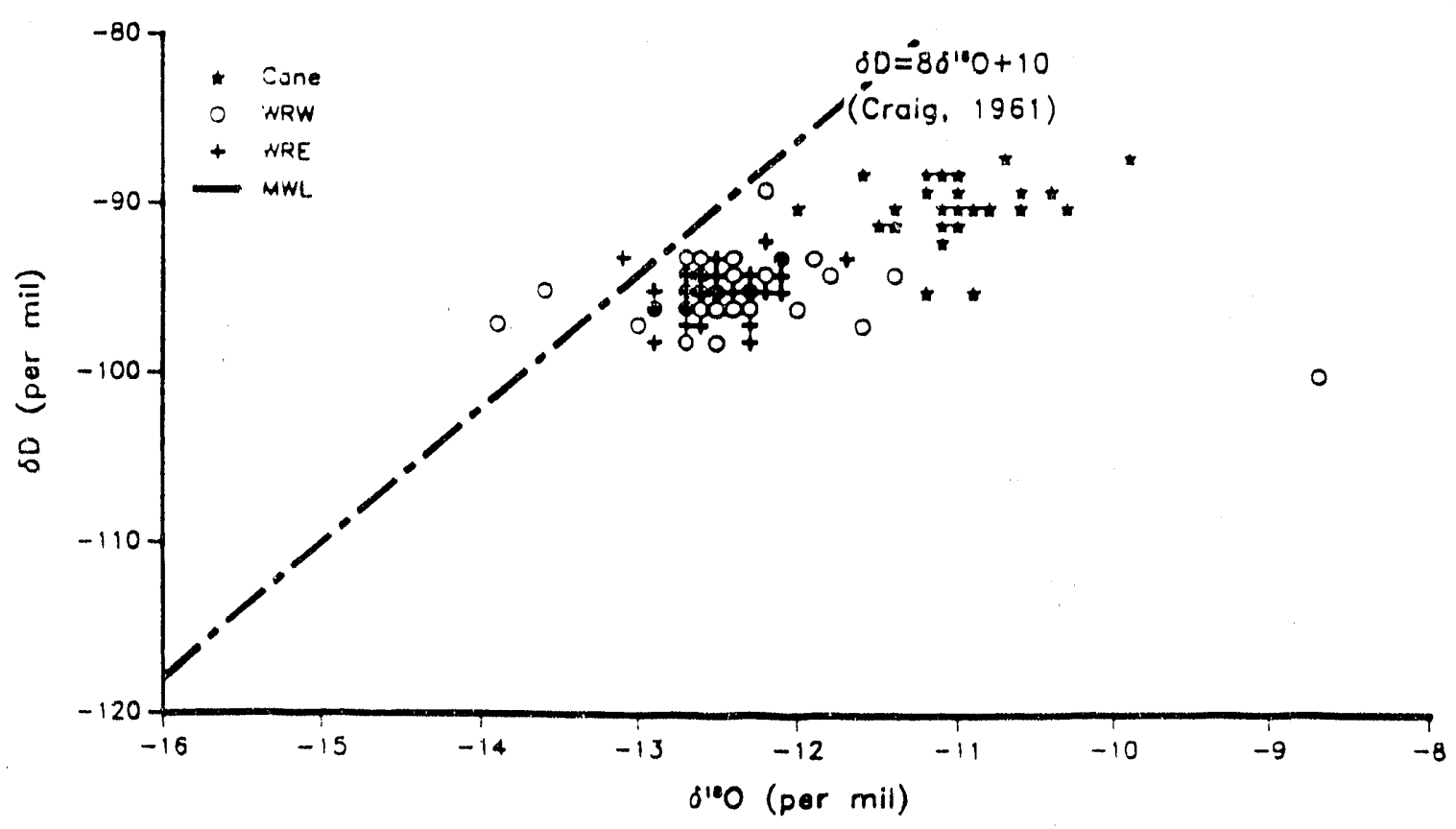

FIGURE 23b. Cane and Whiterock Springs $-\delta D$ versus $\delta^{18} \mathrm{O}$. 


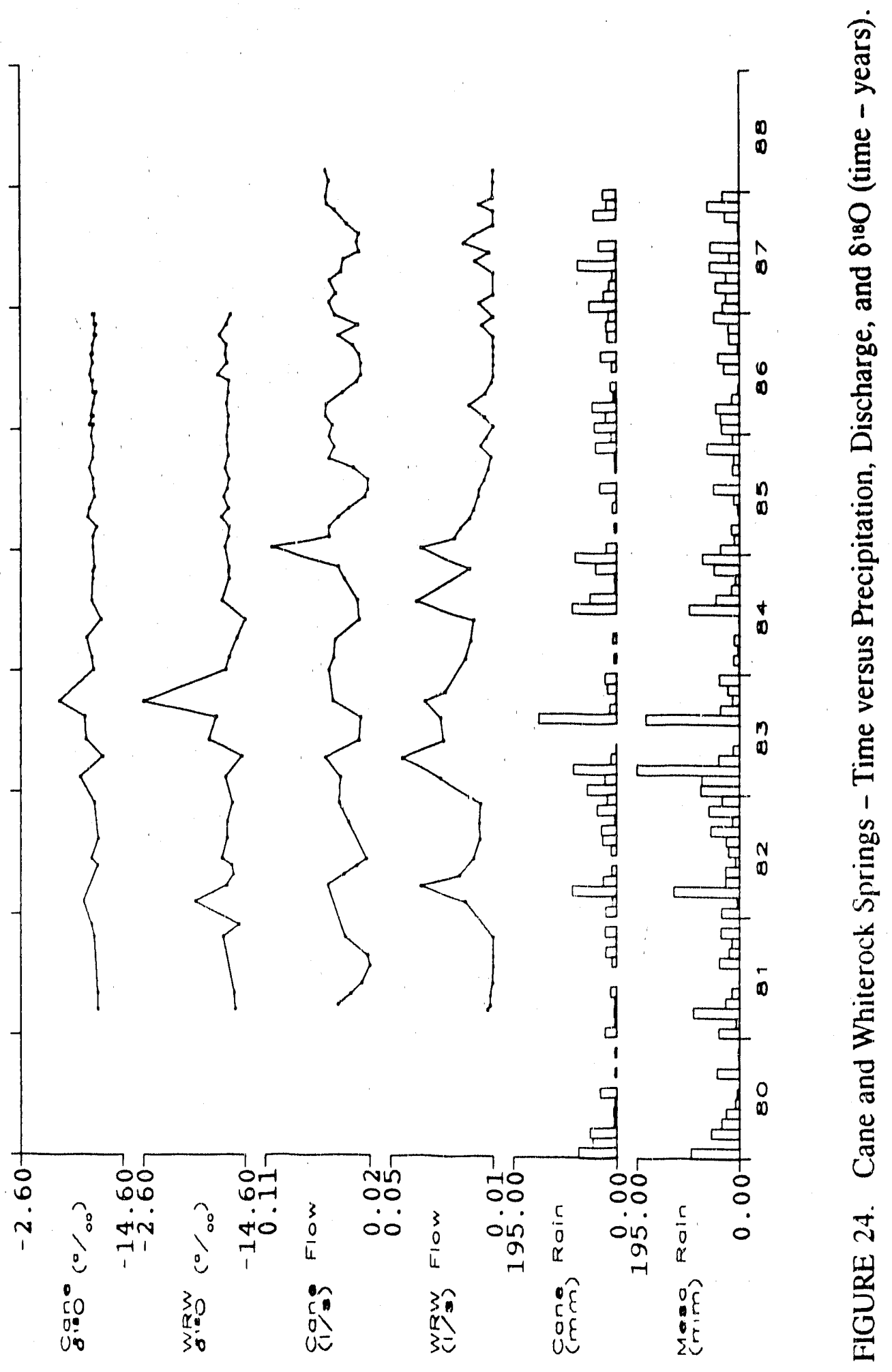


val) to the thundershower in August 1983. Equally, both springs exhibited $\delta^{18} \mathrm{O}$ enrichment after a two-month lag of precipitation isotopes.

A comparison of high-frequency micrologger data from May 1987 at Cane and Whiterock Springs is shown on Figure 25. In this figure, the y sub-axis is set to the maximums and minimums observed over the time period. Both springs showed a doubling of flow in response to precipitation on May 15 and 16. Precipitation duration was similar at both sites, however, precipitation intensity at Cane Spring was over twice that observed at Whiterock Spring. Cane Spring, although receiving twice as much rain, responded much slower than Whiterock Spring. Cane Spring showed a lag time of 10 hours and a total flow response time of 24 hours, with no significant change in EC. Whiterock Spring, on the other hand, showed a lag time of 2 hours and a total response time of 17 hours, with a significant change in EC (nearly 50 percent), with a lag time of 8 hours. Although data are not available to calculate hydraulic properties of the aquifer, the aforementioned case suggests that recharge waters move rapidly through the unsaturated zone and have a more pronounced effect on aquifer chemistry at Whiterock Spring than at Cane Spring. This can be accounted for several ways: 1) a thinner, more mineralized, soil cover exists at Whiterock than at Cane; 2) coarser, higher permeability sediments exist in the Whiterock recharge area; 3 ) higher fracture permeability at Whiterock; or 4) some combination of these factors.

The following conceptual model is theorized as one possible explanation for the observed infiltration/discharge variations:

Extreme precipitation events (similar to the May 1987 event) infiltrate through relatively thin soil cover in the recharge area as matrix flow and then flow quickly through the unsaturated volcanic rock as fracture flow. The spring discharge response time (lag time from the start of precipitation until the increased spring discharge) is a measure of the infiltration flux rate. Once recharge waters contact the water table, a pressure pulse is transmitted through the aquifer, resulting in increased discharge. The water table (potentiometric surface) is elevated during this period, allowing water to contact minerals in the transition zone immediately above the water table. These responses occur relatively quickly, within 24 hours at Cane and Whiterock Springs. Based on the nearly two-month lag time observed for the transmission of oxygen isotopes from an anomalous precipitation event, it is further hypothesized that recharge waters and groundwaters do not thoroughly mix prior to discharge. This may account for the wide age distribution observed at Cane Spring (30 to 600 years). No carbon analysis was run from the other springs; therefore, a similar phenomenon cannot be ruled out for these springs. Therefore, it is surmised that re- 


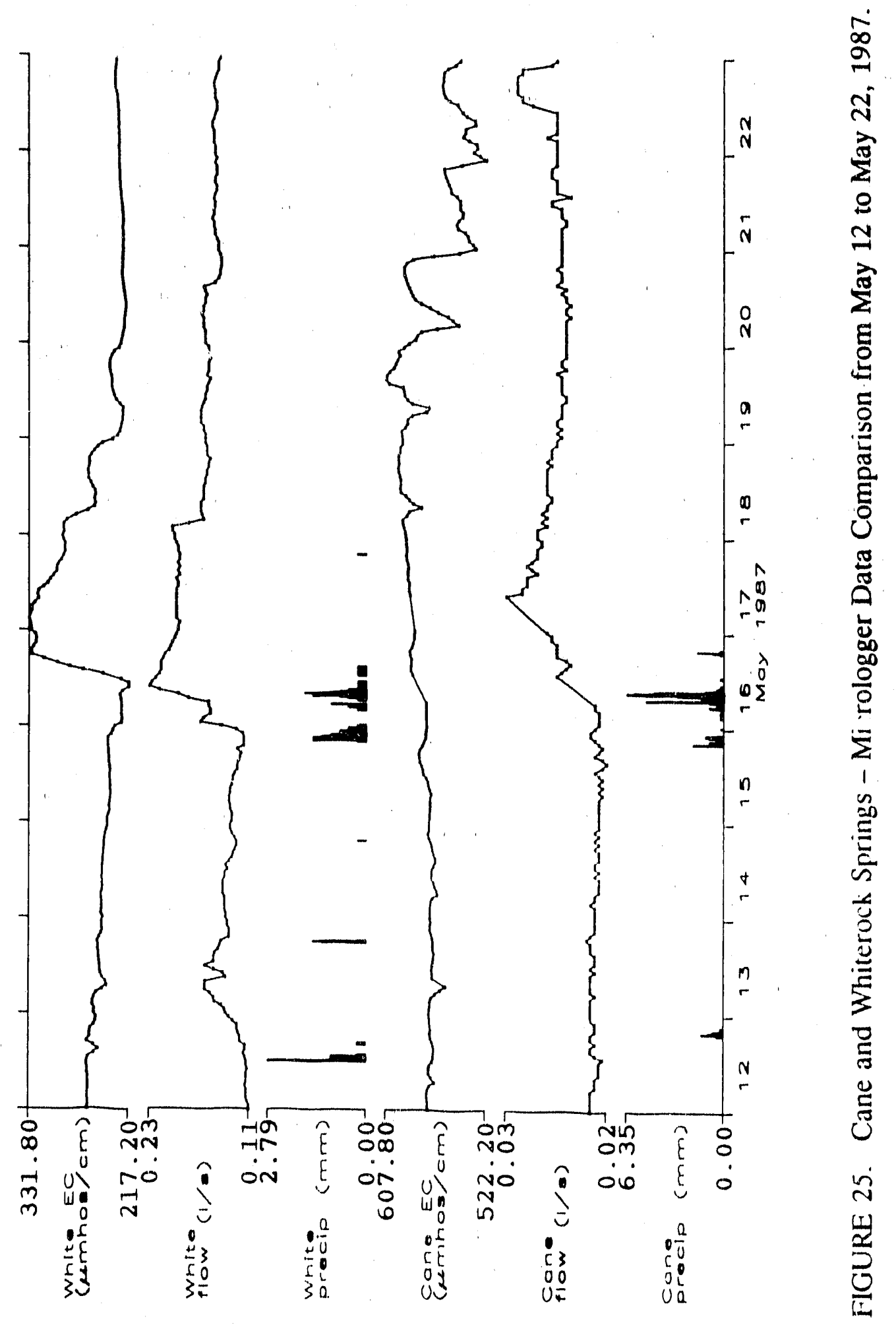


charge waters may migrate rapidly along the water table, with a travel time as short as two to three months, compared to the previously accepted travel times coincident with the rnean groundwater age (approximately 30 years).

\section{CONCLUSIONS}

The original purpose of this investigation was to: 1) estimate the minimum precipitation threshold required to initiate flow responses at seiected springs; 2 ) measure the spring discharge response time caused by precipitation events to estimate travel time through the unsaturated zone; 3) measure the variation of EC to better. understand how dissolved solids in the water change with time; and 4) to test field acquisition systems.

Data from microloggers installed at Cane and Whiterock Springs were used to estimate the minimum precipitation threshold. Characteristics of the recharge area, such as soil volumetric moisture content, soil permeability, soil thickness, soil temperature, and snowpack, are factors controlling the travel time through the unsaturated zone; however, measurements of these parameters are beyond the scope of this study. Therefore, estimates of the minimum precipitation threshold for these sites are based on discharge response and non-response to various precipitation events. Several low-intensity precipitation events were observed to produce minor spring discharge variations at both sites. Due to the low number of such events observed during the study, only a range of precipitation mass and duration can be concluded here (Table 25). To further refine these estimates, it would be necessary to monitor precipitation and spring discharge over a period of time sufficient to observe approximately 10 precipitation events between the higher and lower values listed in Table 25.

An extreme precipitation event in May 1987 was observed to produce discernible discharge responses at both Cane and Whiterock Springs. Cane Spring, although received twice as much rain, responded much slower than Whiterock Spring. Cane Spring showed a lag time of 10 hours and a total flow response time of 24 hours, with no significant change in EC. Whiterock Spring, on the other hand, showed a lag time

TABLE 25. ESTIMATED MINIMUM PRECIPITATION THRESHOLD NEEDED TO PRODUCE SPRING DISCHARGE RESPONSE AT CANE AND WHITEROCK SPRINGS.

\begin{tabular}{lccccc}
\hline & \multicolumn{2}{c}{ Lower } & & \multicolumn{2}{c}{ Higher } \\
\cline { 2 - 5 } & $\begin{array}{c}\text { Mass } \\
(\mathrm{cm})\end{array}$ & $\begin{array}{c}\text { Duration } \\
(\mathrm{min})\end{array}$ & & $\begin{array}{c}\text { Mass } \\
(\mathrm{cm})\end{array}$ & $\begin{array}{c}\text { Duration } \\
(\mathrm{min})\end{array}$ \\
\hline Cane & 1.10 & 45 & 4.75 & 540 \\
Whiterock & 0.30 & 45 & 0.63 & 135 \\
\hline
\end{tabular}


of 2 hours and a total response time of 17 hours, with a significant change in EC (nearly 50 percent), with a lag time of 8 hours. Although data are not available to calculate hydraulic properties of the aquifer, the aforementioned case suggested that recharge waters move rapidly through the unsaturated zone and have a more pronounced effect on aquifer chemistry at Whiterock Spring than at Cane Spring. This can be accounted for several ways: 1) a thinner, more mineralized, soil cover exists at Whiterock than at Cane; 2) coarser, higher permeability sediments exist in the Whiterock recharge area; 3 ) higher fracture permeability at Whiterock; or 4) some combination of these factors.

Various dissolved ions and isotopes were analyzed and electrical conductance was measured as a function of time during this study. An isotopically discernible precipitation event (August 1983) was observed in precipitation samplers near Cane and Whiterock Springs. The $\delta^{18} \mathrm{O}$ signature was nearly $7 \%$ enriched above the average observed near Cane Spring, and was nearly $4 \%$ enriched near Whiterock Spring. This isotopically distinct water was observed 2 to 2.5 months later as discharge at Cane and Whiterock Springs; however, the sample frequency was monthly, so the exact lag time cannot be estimated. Electrical conductivity data from the microloggers suggest that Whiterock Spring also responds to dissolution of soluble salts within 8 hours of increased spring discharge, which is thought to be associated with mineral dissolution along fractures near the spring discharge point (as presented in the previous section). This quick dissolution response was not observed at Cane Spring, but an increase in major cations and anions was observed to coincide with the isotopic pulse (two-month lag). Whiterock Spring ion chemistry appeared to respond more rapidly, approximately one month. Therefore, it is concluded: 1) the majority of dissolved ions are associated with mineral dissolution in the soil zone and take one to two months to be transmitted to the spring discharge point; and 2) mineral dissolution occurs near the spring discharge point as the quasi-equilibrium water table rises due to pressure pulse responses from infiltrating recharge water.

Finally, the field acquisition techniques employed include manual field measurements, chart recorders, and computerized microloggers. The computerized micrologger system was by far superior to the chart recorder employed at the onset of thi study. Real-time clata was made available to the microloggers via telephone lines, making error checking and data acquisition much easier. However, it should be noted that field verification is imperative to assure data quality. 


\section{REFERENCES}

Barnes, H., F.N. Houser and F.G. Poole, 1963. "Geologic Map of the Oak Springs Quadrangle, Nye County, Nevada," U.S. Geological Survey, Map: GQ-214.

Bodine, W.M. and B.F. Jones, 1986. "The Salt Norm: A Quantitative Chemical-Mineralogical Characterization of Natural Waters," U.S. Geological Survey, WRI 86-4086, 130 o.

Bohm, B. and R.L. Jacobson, 1981. "WATEQDR, An Updated Version of WATEQF - A Computerized Chemical Model of Natural Waters," Desert Rejearch Institute, Water Resources Center, August 1981.

Boughton, C.J., 1986. "Integated Geochemical and Hydraulic Analyses of Nevada Test Site Ground Wate. Systems," Unpublished Masters Thesis, University of Nevada-Reno, May 1986, 135 p.

Claassen, H.C., 1973. "Water Quality and Physical Characteristics of Nevada Test Site Water-Supply Wells," U.S. Geological Survey, USGS-474-158, NTS-242, $145 \mathrm{p}$.

Craig, H., 1961. "Isotopic Variation in Meteoric Waters," Science, Vol. 133, No. 3465, pp. 1702-1703.

Davis, J.C., 19 13. "Statistics and Data Analysis in Geology," John Wiley and Sons, New York, 550 p.

Drever, J.I., 1982. "The Geochemistry of Natural Waters," Prentice-Hall, Inc., Englewood Cliffs, New Jersey, 388 p.

French, R.H., 1986. "Daily, Seasonal, and Annual Precipitation at the Nevada Test Site, Nevada," Desert Research Institute, Water Resources Center, Pub. No. 45042,57 p.

Fritz, P. and J.Ci.. Fontes, 1980. "Handbook of Environmental Isutope Geochemis. try," Elsevier Scientific Publishing Co., Amsterdam, Vol. 1, 545 p.

Garrels, R.M. and F.T. Mackenzie, 1967. "Origi Geochemical Compositions of Some Springs and Lakes," Equilibrium Concep. in Natural Water Systems, American Cheni. Scic. Adv. Chem. Ser. 67, pp. 222-242.

Gibbons, A.B., E.N. Hinrichs, W.R. Hansen and R.W. Lemke, 1963. "Geology of the Rainier Mesa Quadrangle, Nye County, Nevada," U.S. Geological Survey, Map: GQ-215. 
Ingraham, N., B.F. Lyles, R.L. Jacobson and J.W. Hess, 1990 stable Isotope Study of Precipitation and Spring Discharge in Southern Nevads." in press.

Jacobson, R.L., 1973. "Controls on the Quality of Some Carbonate Groundwaters: Dissociation Constants of Calcite and $\mathrm{CaHCO}_{3}^{+}$from 0 to $50^{\circ} \mathrm{C}$," Unpublished Doctoral Dissertation, Pennsylvania State University, June 1973, 131 p.

Kolb, W.M., 1983. "Curve Fitting for Programmable Calculators," Second Edition, IMTEC, P.O. Box 1402, Bowie, Maryland 20716, 115 p.

Larson, G.L., R.C. Mathews, Jr. and R. Herrmann, 1986. "Limestone Influences on Physical and Chemical Features of a Mountain Stream," Ground Water, Vol. 24, No. 2, pp. 166-172.

Lyles, B.F., 1985. "Time-Variant Hydrogeologic and Geochemical Study of Selected Thermal Springs in Western Nevada," Unpublished Masters Thesis, University of Nevada-Reno, August 1985, 203 p.

Orkild, P.P., 1963. "Geologic Map of the Tippipah Spring Quadrangle, Nye County, Nevada," U.S. Geological Survey, Map: GQ-213.

Orkild, P.P. and J.T. O'Connor, 1970. "Geologic Map of the Topopah Spring Quadrangle, Nye County, Nevada," U.S. Geological Survey, Map: GQ-849.

Poole, F.G., D.P. Elston and W.J. Carr, 1965. "Geologic Map of the Cane Spring Quadrangle, Nye County, Nevada," U.S. Geological Survey, Map: GQ-455.

Sara, M.N., 1977. "Hydrogeology of Redwood Canyon, Tulare County, California," Unpublished Masters Thesis, University of Southern California, September 1977, 129 p.

Teledyne isotopes, 1982. Radiocarbon Laboratory, Westwood, New Jersey, Personal Communication.

Trudeau, D.A., 1979. "Hydrogeologic Irivestigution of the Littlefield Springs," Unpublished Masters Thesis, University of Nevada-Reno, August 1979, $136 \mathrm{p}$.

Winograd, I.J. and W. Thordarson, 1968. "Structural Control of Ground-Water Movement in Miogeosynclinal Rouks of South-Central Nevada," Eckel, E.B.. edit.. Nevada Test Site, Geol. Soc. America Mem., 110, fp. 35-48.

winograd. i.j. and $\dddot{w}$. Thordarson, 1975. "hydrogeoiogic and Hydrochemicai Framework, South-Central Great Basin, Nevada-Califorrua, with Special Reference to the Nevada Test Site," U.S. Geological Survey Professional Paper 712-C. $126 \mathrm{p}$. 


\section{APPENDIX A}

CALIBRATION OF 11.25 DEGREE V-NOTCH WEIR 
Discharge measurements were made with a stopwatch and volumetric cylinder and Cane and Whiterock Springs each time the spring was visited. To accurately measure discharge for high frequency analysis, it was necessary to design an 11.25 degree $\mathrm{V}$-notch weir. A calibration weir and box were constructed with the following dimensions:

Weir Box

$$
\begin{aligned}
& \text { Length }=65 \mathrm{~cm} \\
& \text { Width }=42 \mathrm{~cm} \\
& \text { Height }=33 \mathrm{~cm}
\end{aligned}
$$

V-Notch

Thickness $=0.1 \mathrm{~cm}$

Width $=21.5 \mathrm{~cm}$

Height $=28 \mathrm{~cm}$

The box was constructed of marine grade three-quarter inch plywood and the $V$ notch was constructed of galvanized steel.

Calibration was conducted over a large range of stage, from $10.75 \mathrm{~cm}$ to 2.15 $\mathrm{cm}$ (equaling $0.7168 \mathrm{l} / \mathrm{sec}$ and $0.0176 \mathrm{l} / \mathrm{sec}$, respectively). Calibration measurements were made by measuring weir stage and timing the discharge from the weir into a volumetric cylinder. Four different collection cylinders were used, depending on the flow rate at the weir. A flow rate $(l / \mathrm{sec})$ was then computed as a function of weir stage $(\mathrm{cm})$. These data (Figure A1) were then run through a curve fitting routine (Kolb, 1983) to develop an equation for discharge versus stage. The best fit curve was a power function:

$$
Q=a h^{b}
$$

where: $\begin{aligned} Q & =\text { flow }(/ / \mathrm{sec}) \\ \mathrm{a} & =0.0027 \\ \mathrm{~b} & =2.34 \\ \mathrm{R}^{2} & =0.999\end{aligned}$




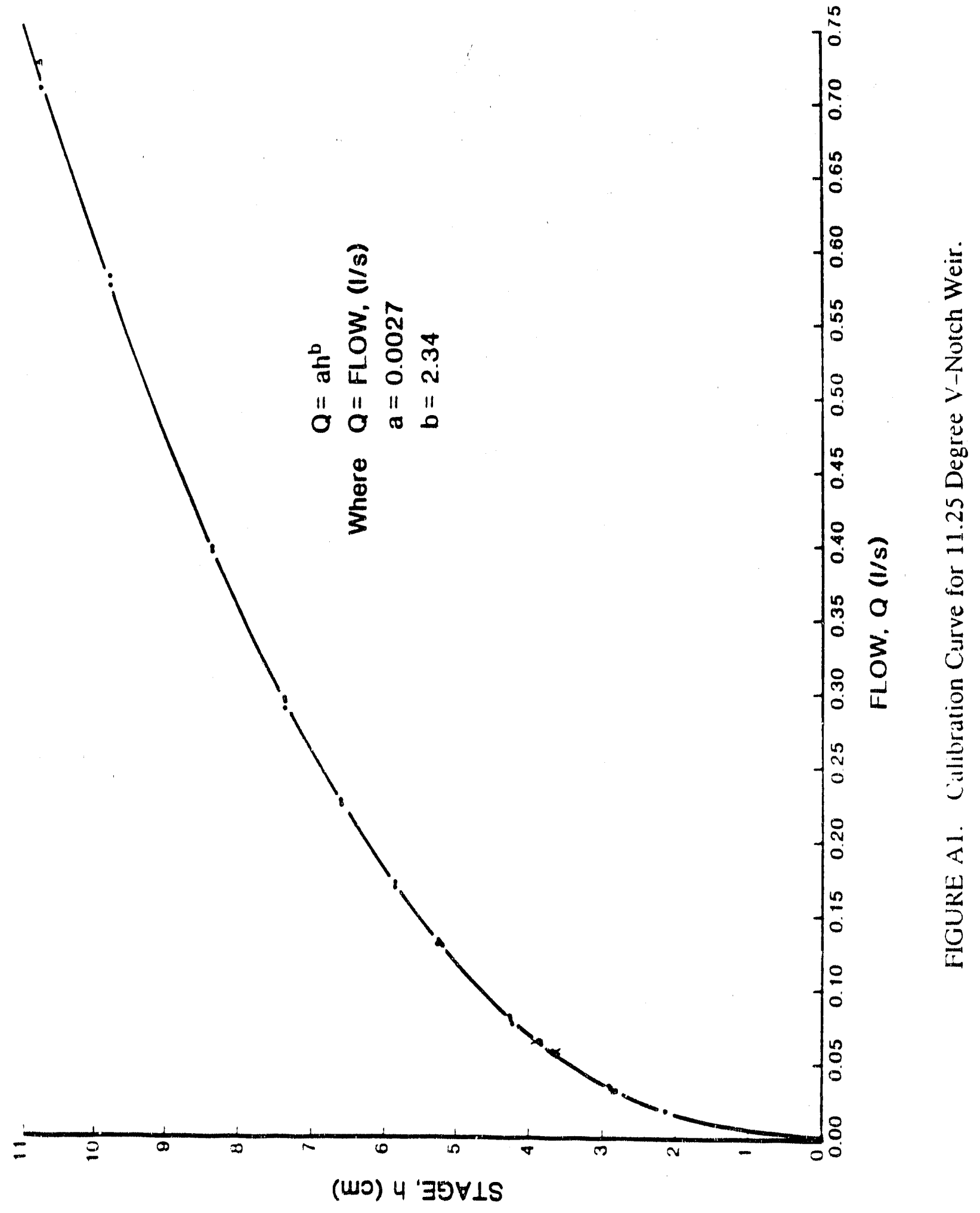




\begin{tabular}{|c|c|c|c|}
\hline $\begin{array}{l}\text { Stage } \\
(\mathrm{cm})\end{array}$ & $\begin{array}{l}\text { Time } \\
(\mathrm{sec})\end{array}$ & $\begin{array}{c}\text { Volume } \\
\text { (liters) }\end{array}$ & $\begin{array}{l}\text { Flow } \\
(\text { lisec })\end{array}$ \\
\hline 10.75 & 72.93 & $52.855 \pm .10$ & 0.725 \\
\hline 10.75 & 72.86 & $52.855 \pm .10$ & \\
\hline 10.75 & 29.56 & $20.986 \pm .10$ & 0.709 \\
\hline 10.75 & 29.60 & $20.986 \pm .10$ & \\
\hline 10.75 & 29.70 & $20.986 \pm .10$ & \\
\hline 9.77 & 90.97 & $52.855 \pm .10$ & 0.580 \\
\hline 9.77 & 91.25 & $52.855 \pm .10$ & \\
\hline 9.77 & 36.59 & $20.986 \pm .10$ & 0.574 \\
\hline 9.77 & 36.37 & $20.986 \pm .10$ & \\
\hline 9.77 & 36.67 & $20.986 \pm .10$ & \\
\hline 8.33 & 133.98 & $52.855 \pm .10$ & 0.395 \\
\hline 8.33 & 134.31 & $52.855 \pm .10$ & \\
\hline 8.33 & 53.20 & $21.214 \pm .1$ & 0.397 \\
\hline 8.33 & 53.50 & $21.214 \pm .1$ & \\
\hline 8.33 & 53.61 & $21.214 \pm .1$ & \\
\hline 8.33 & 53.35 & $21.214 \pm .1$ & \\
\hline 7.35 & 180.11 & $52.855 \pm .1$ & u... \\
\hline 7.35 & 180.13 & $52.855 \pm .1$ & \\
\hline 7.35 & 72.01 & $21.214 \pm .1$ & 0.295 \\
\hline 7.35 & 71.87 & $21.214 \pm .1$ & \\
\hline 7.35 & 72.05 & $21.214 \pm .1$ & \\
\hline 7.35 & 14.56 & $4.1455 \pm .01$ & 0.238 \\
\hline 7.35 & 14.31 & $4.1455 \pm .01$ & \\
\hline 7.35 & 14.50 & $4.1455 \pm .01$ & \\
\hline 7.35 & 14.24 & $4.1455 \pm .01$ & \\
\hline 7.35 & 14.43 & $4.1455 \pm .01$ & \\
\hline
\end{tabular}




\begin{tabular}{|c|c|c|c|}
\hline $\begin{array}{l}\text { Stage } \\
(\mathrm{cm})\end{array}$ & $\begin{array}{l}\text { Time } \\
(\mathrm{sec})\end{array}$ & $\begin{array}{c}\text { Volume } \\
\text { (liters) }\end{array}$ & $\begin{array}{l}\text { Flow } \\
(1 / \mathrm{sec})\end{array}$ \\
\hline 6.60 & 93.90 & $21.295 \pm .1$ & 0.227 \\
\hline 6.60 & 93.87 & $21.295 \pm .1$ & \\
\hline 6.60 & 93.83 & $21.295 \pm .1$ & \\
\hline 6.60 & 18.39 & $4.1455 \pm .01$ & 0.223 \\
\hline 6.60 & 18.58 & $4.1455 \pm .01$ & \\
\hline 6.60 & 18.71 & $4.14 .55 \pm .01$ & \\
\hline 5.85 & 124.72 & $21.295 \pm .1$ & 0.171 \\
\hline 5.85 & 124.78 & $21.295 \pm .1$ & \\
\hline 5.85 & 124.76 & $21.295 \pm .1$ & \\
\hline 5.85 & 24.80 & $4.1455 \pm .01$ & 0.168 \\
\hline 5.85 & 24.69 & $4.1455 \pm .01$ & \\
\hline 5.85 & 24.70 & $4.1455 \pm .01$ & \\
\hline 5.24 & 162.66 & $21.295 \pm .1$ & 0.129 \\
\hline 5.225 & 164.18 & $21.295 \pm .1$ & \\
\hline 5.20 & 166.02 & $21.384 \pm .1$ & \\
\hline 5.20 & 165.60 & $21.295 \pm .1$ & \\
\hline 5.25 & 32.76 & $4.2215 \pm .01$ & 0.129 \\
\hline 5.25 & 32.73 & $4.2289 \pm .01$ & \\
\hline 5.25 & 32.79 & $4.2289 \pm .01$ & \\
\hline 4.24 & 53.24 & $4.2413 \pm .01$ & 0.079 \\
\hline $4.2 ?$ & 53.37 & $4.2413 \pm .01$ & \\
\hline 4.23 & 53.51 & $4.2413 \pm .01$ & \\
\hline 4.23 & 12.35 & $.993 \pm .001$ & 0.080 \\
\hline 4.23 & 12.28 & $.993 \pm .001$ & \\
\hline 4.23 & 12.48 & $.993 \pm .001$ & \\
\hline
\end{tabular}




\begin{tabular}{llll}
$\begin{array}{c}\text { Stage } \\
(\mathrm{cm})\end{array}$ & $\begin{array}{c}\text { Time } \\
(\mathrm{sec})\end{array}$ & $\begin{array}{l}\text { Volume } \\
\text { (liters) }\end{array}$ & $\begin{array}{c}\text { Flow } \\
(\mathrm{l} / \mathrm{sec})\end{array}$ \\
\hline 3.84 & 67.53 & $4.2425 \pm .01$ & 0.063 \\
3.84 & 67.61 & $4.2425 \pm .01$ & 0.063 \\
\hline 3.84 & 15.70 & $.997 \pm .001$ & \\
3.84 & 15.74 & $.997 \pm .001$ & \\
3.84 & 15.68 & $.997 \pm .001$ & 0.032 \\
\hline 2.88 & 30.63 & $1.000 \pm .001$ & \\
2.87 & 30.93 & $1.000 \pm .001$ & \\
2.85 & 31.62 & $1.000 \pm .001$ & \\
2.84 & 31.81 & $1.000 \pm .001$ & \\
2.84 & 32.21 & $1.000 \pm .001$ & \\
2.84 & 32.31 & $1.000 \pm .001$ & \\
\hline 2.15 & 57.38 & $1.000 \pm .001$ & \\
2.15 & 56.88 & $1.000 \pm .001$ & \\
2.15 & 56.92 & $1.000 \pm .001$ & \\
2.15 & 56.68 & $1.000 \pm .001$ & \\
2.15 & 56.84 & $1.000 \pm .001$ & \\
\hline
\end{tabular}




\section{APPENDIX B}

TIME-SERIES DISCHARGE MEASUREMENTS FROM SELECTED SPRINGS ON THE NTS 
Spring discharge measurements were made by timing flow into a volumetric cylinder and are presented in $1 / \mathrm{sec}$. 


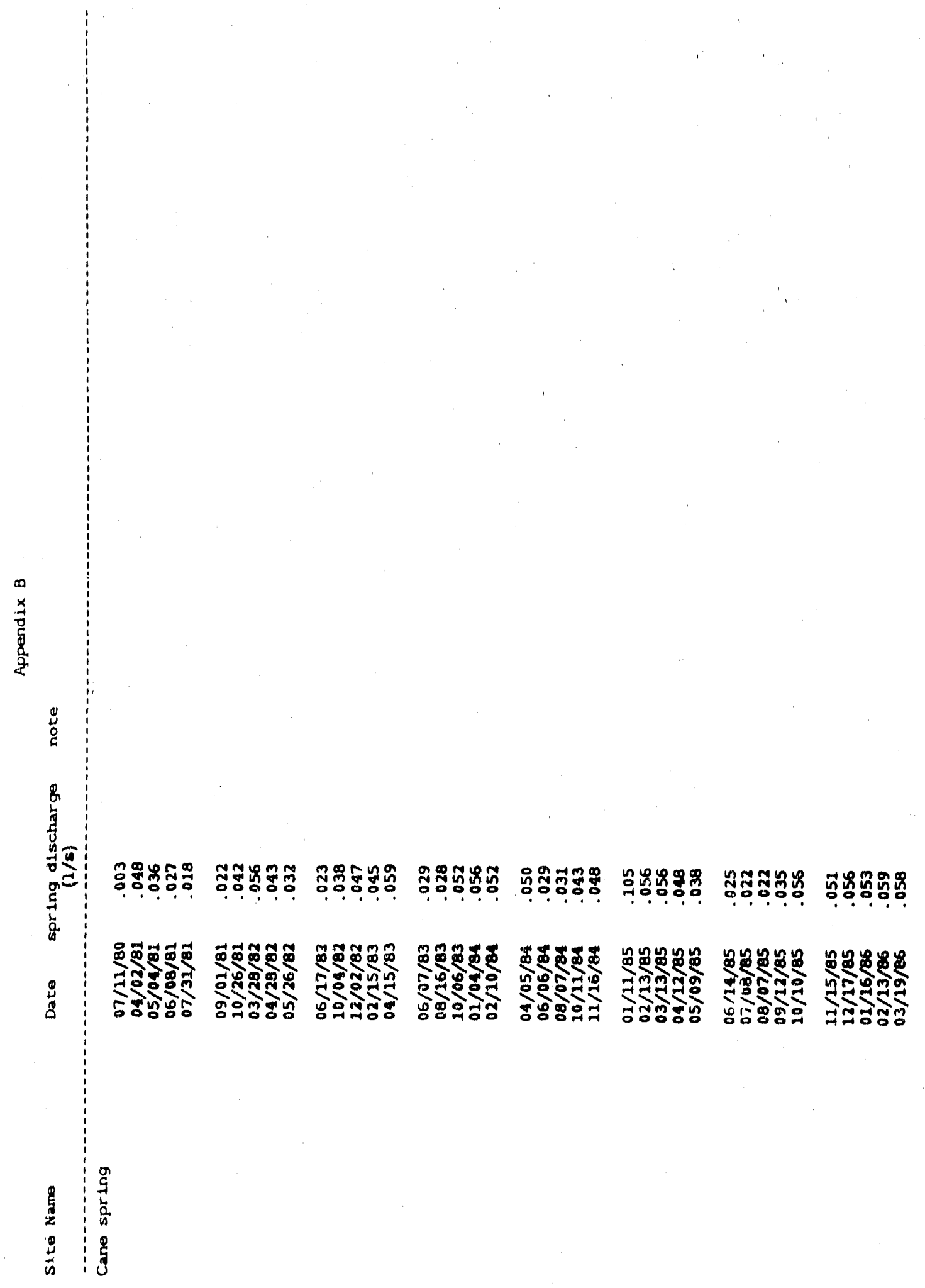




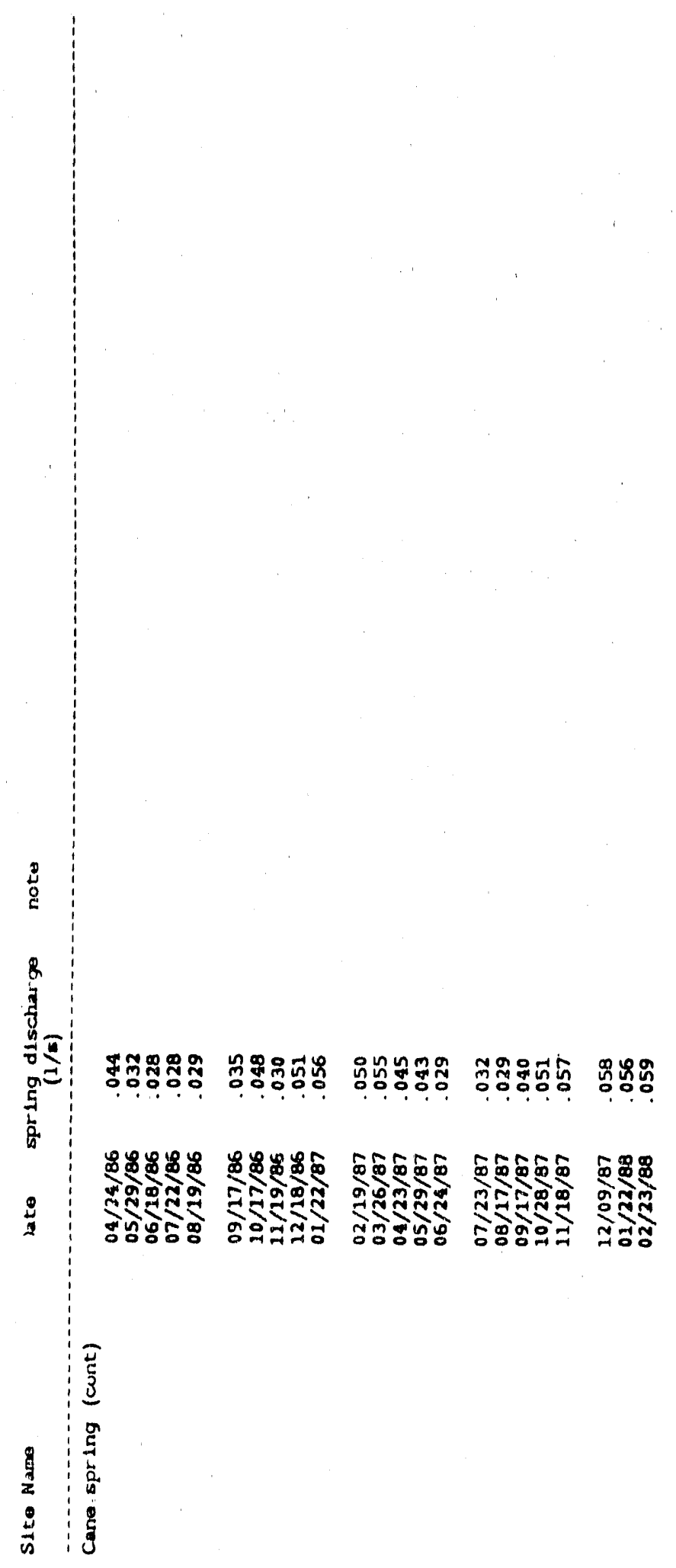




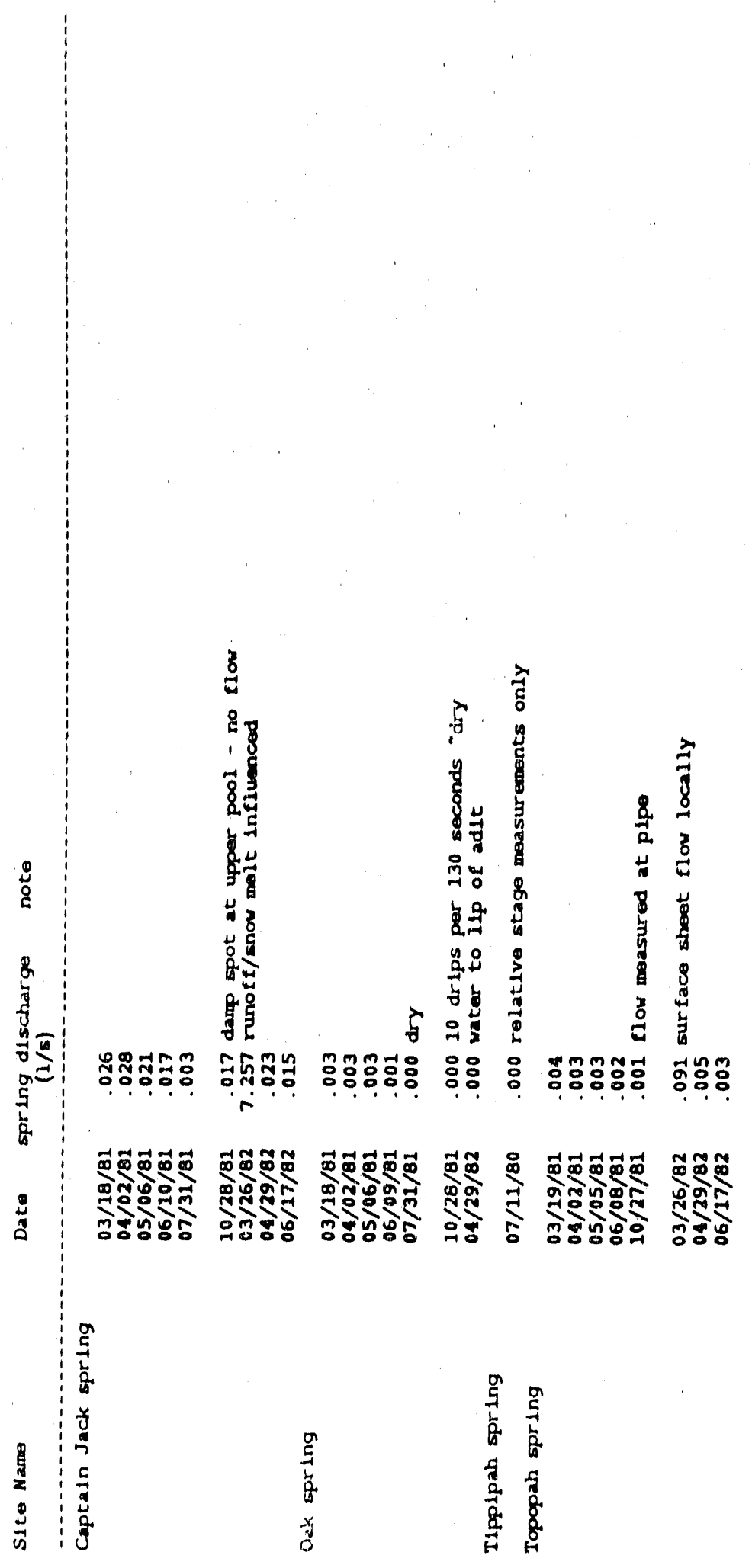




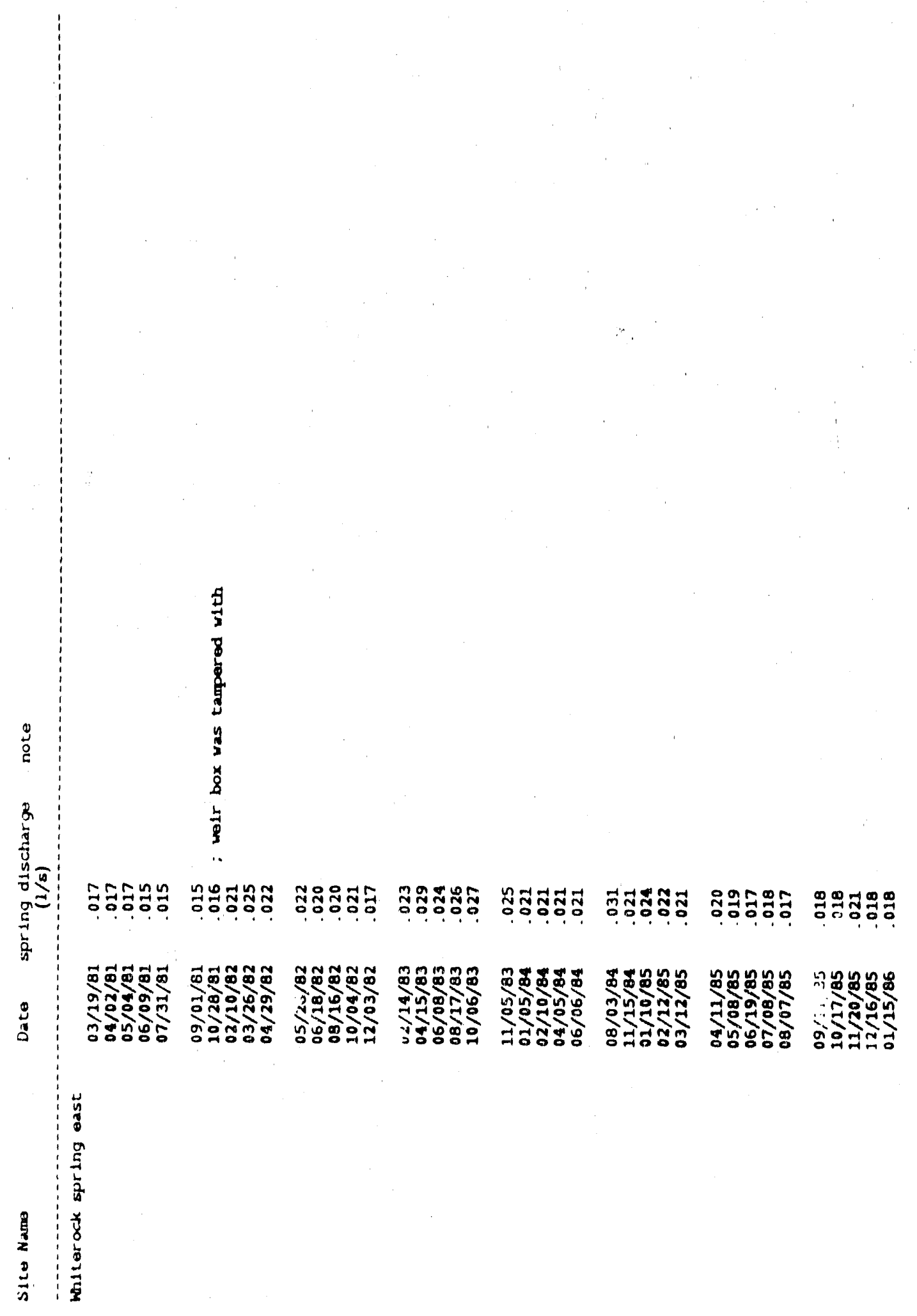




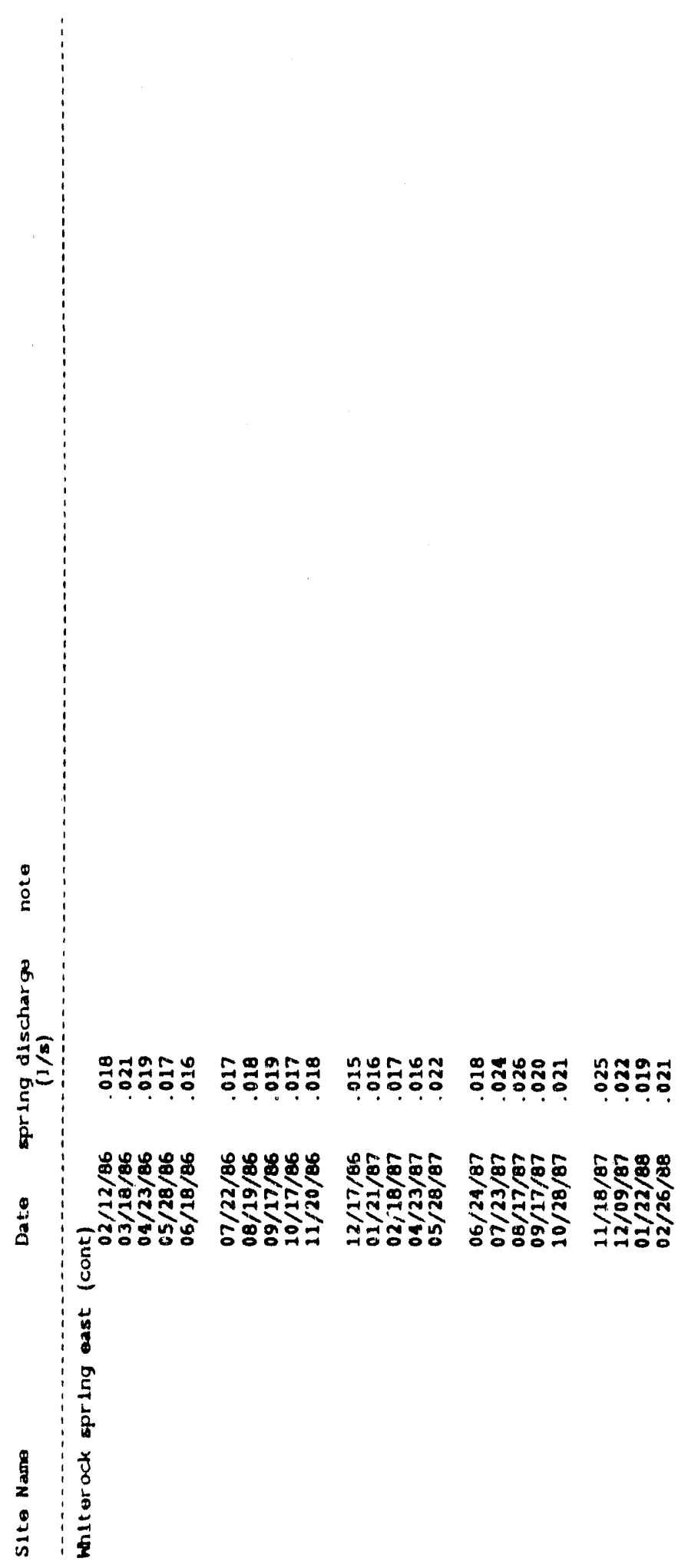




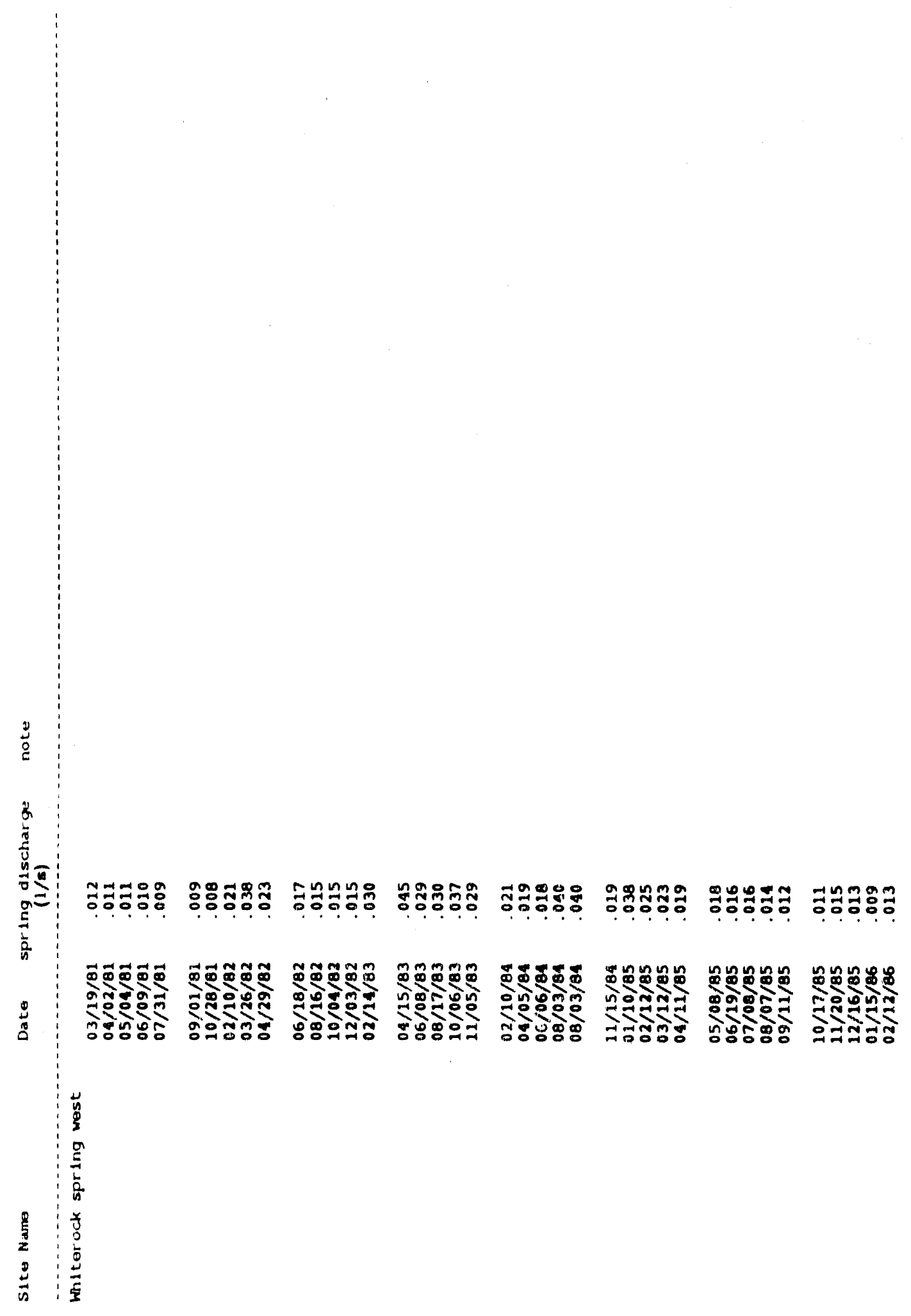




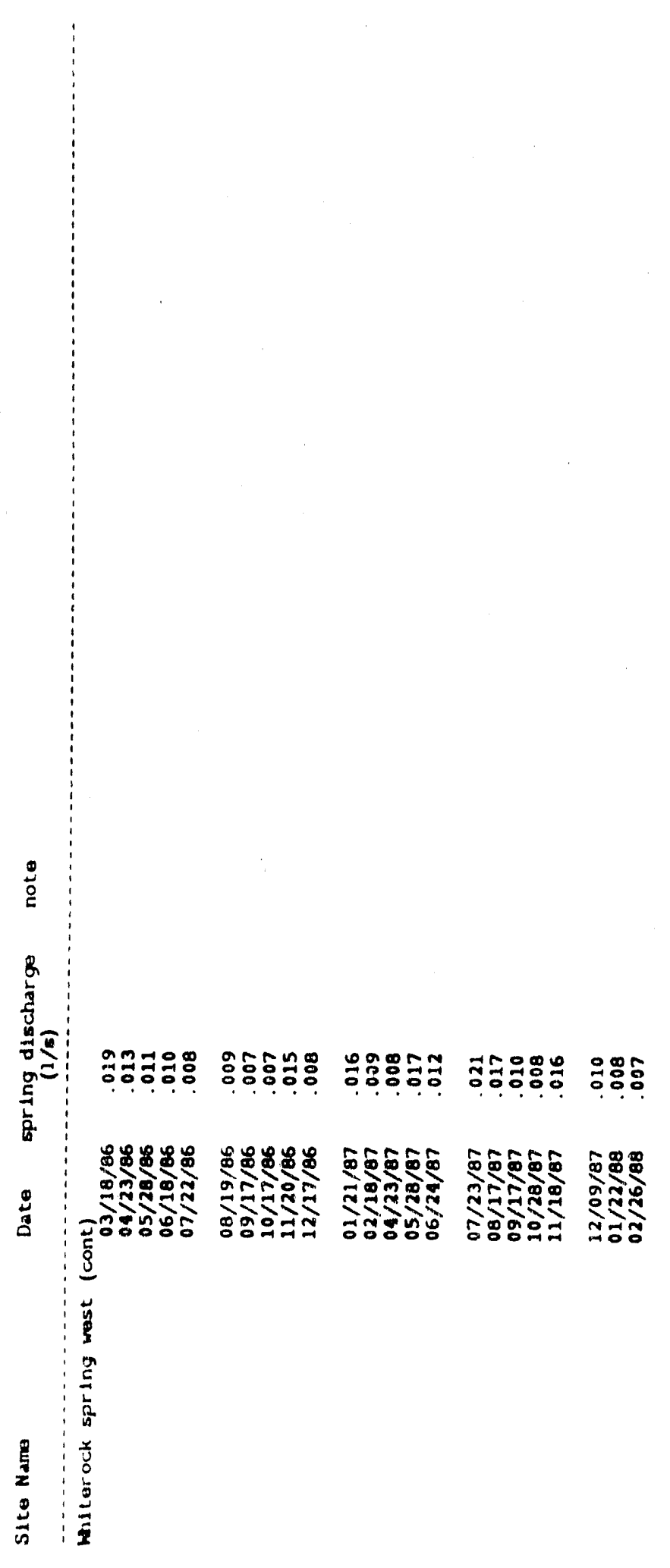




\section{APPENDIX C}

\section{TIME-SERIES CHEMISTRY FROM SELECTED SPRINGS ON THE NTS}


Water chemistry analyses are presented in $\mathrm{mg} / \mathrm{l}$, temperature in degrees centigrade, and electrical conductance in $\mu \mathrm{mhos} / \mathrm{cm} @ 25^{\circ} \mathrm{C}$. 


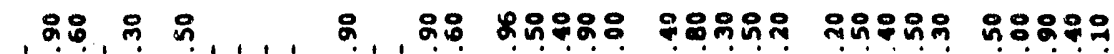

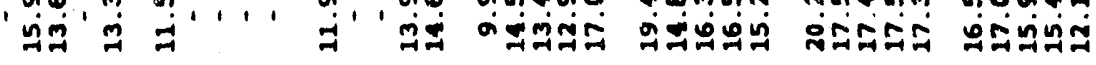
$, 00,00,10,0,000$ 0.0000 00000 00000 00000

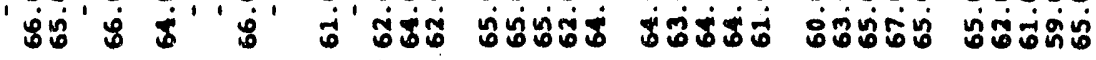
$00,00,1,0,000,0000000000$ 00000 00000 茴

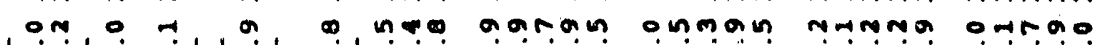

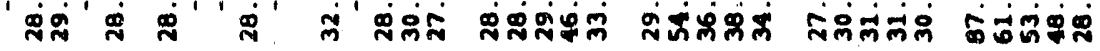

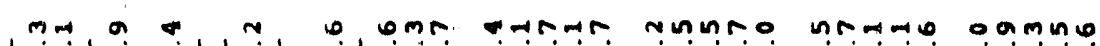

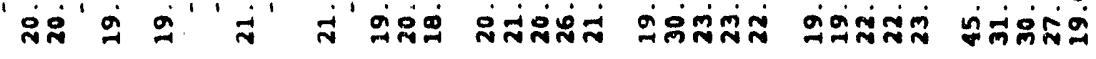

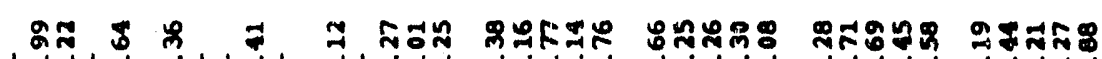

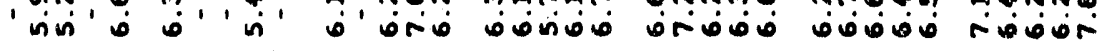

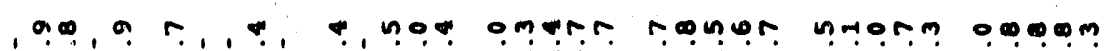

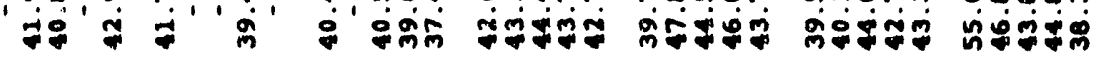

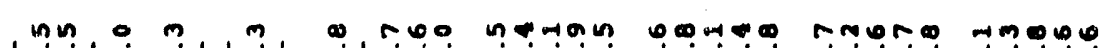

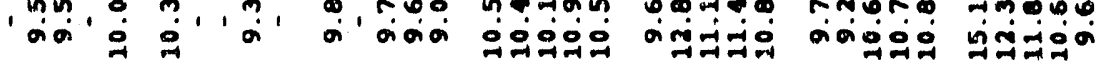

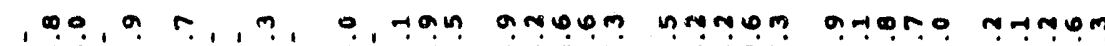

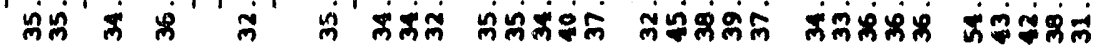

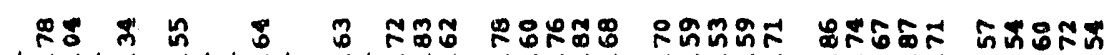

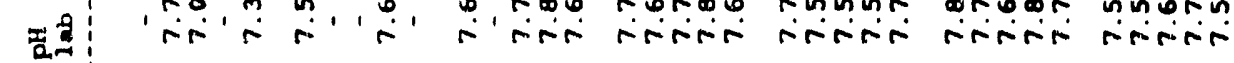

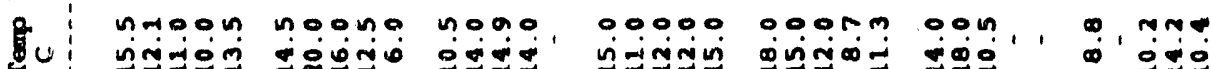

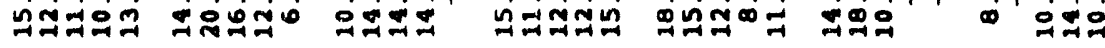

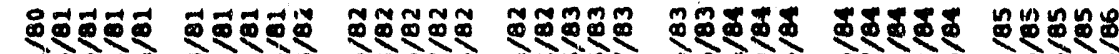

造 


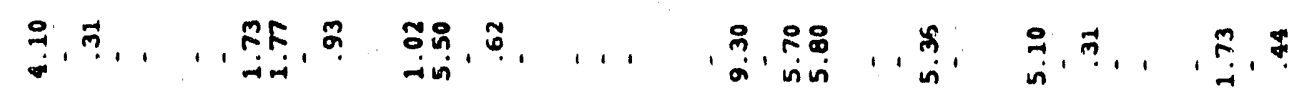

$0,00,0,00,000,000,1,0,000,0,0,000,0,0$

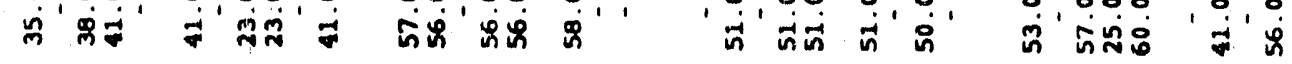

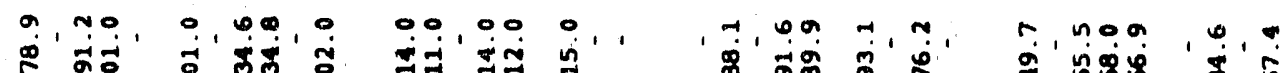

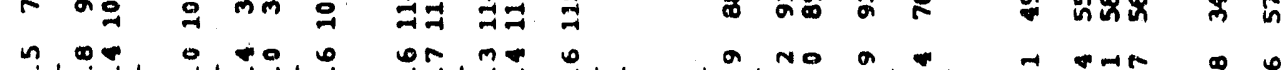

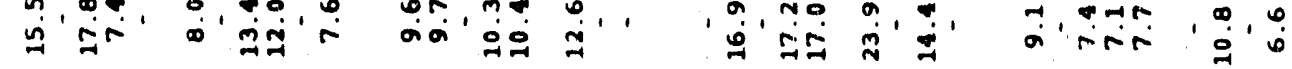

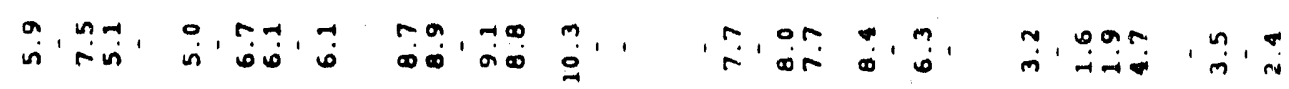

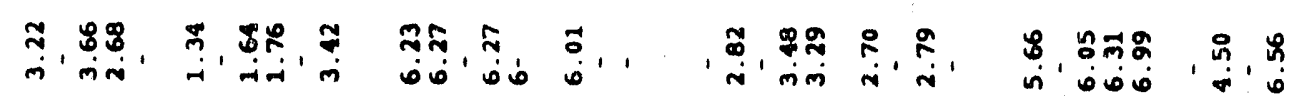

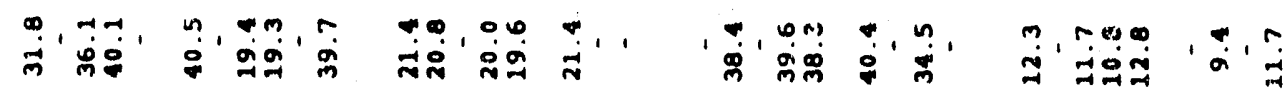

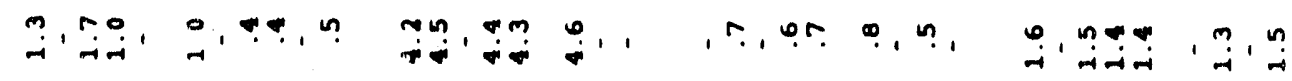

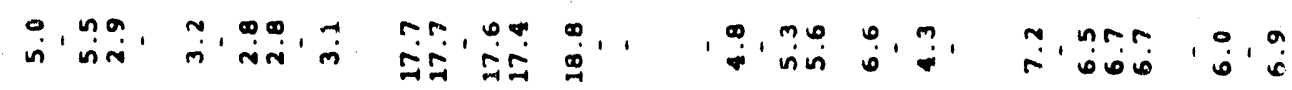

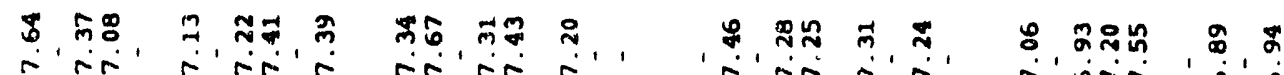

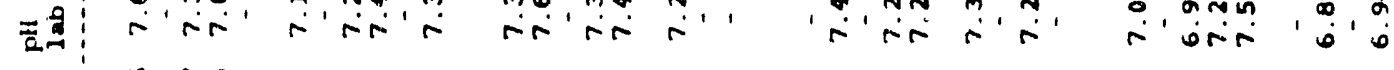

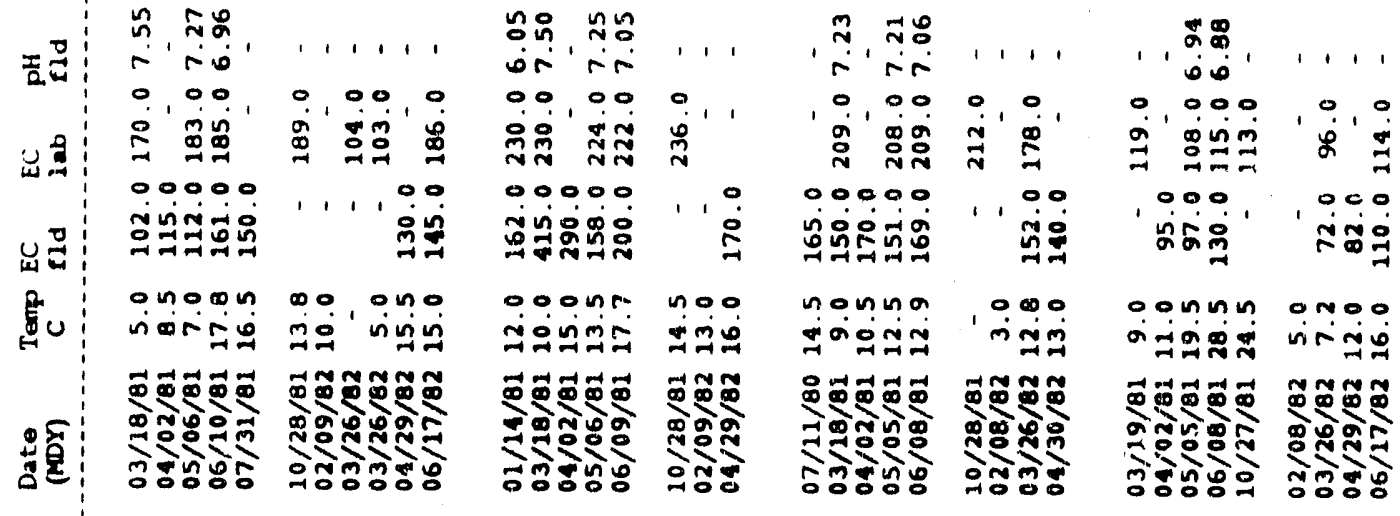

$\frac{9}{5}$
$\frac{1}{6}$
$\frac{1}{3}$

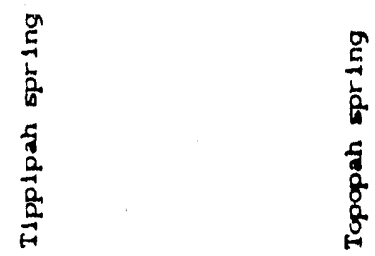




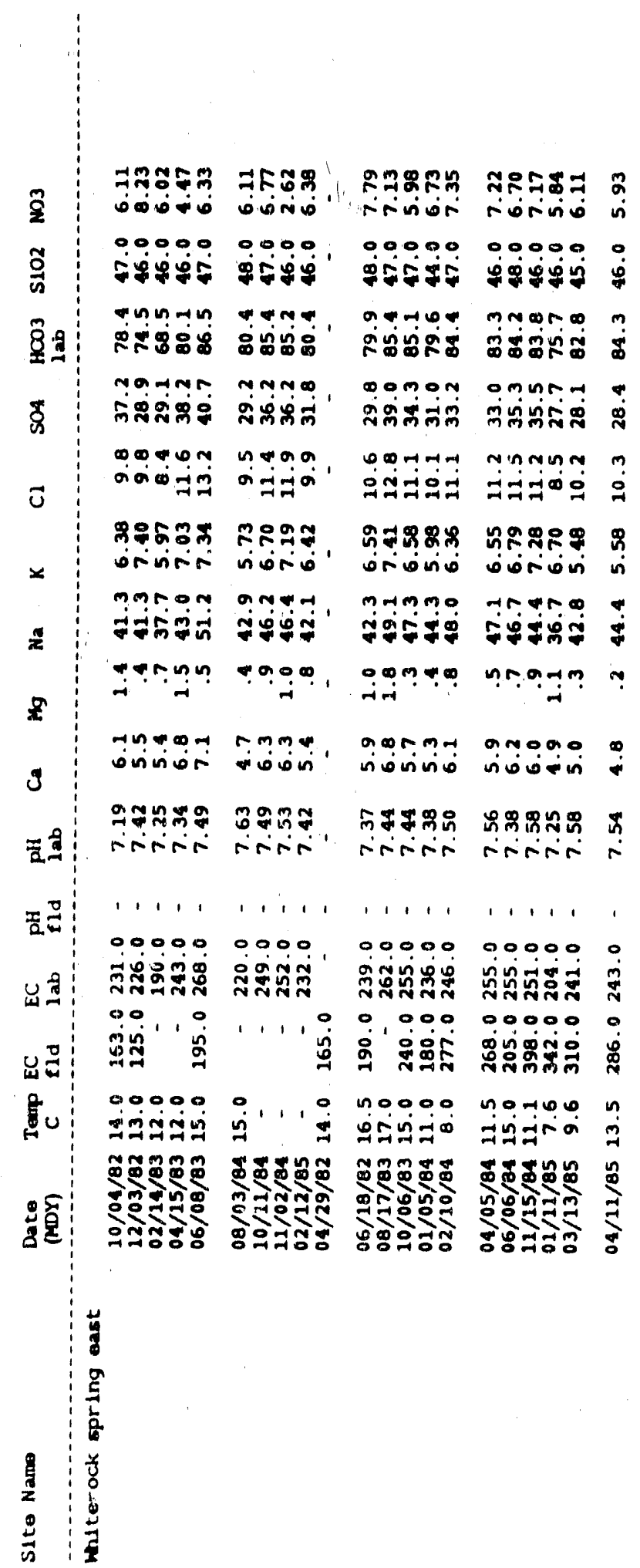




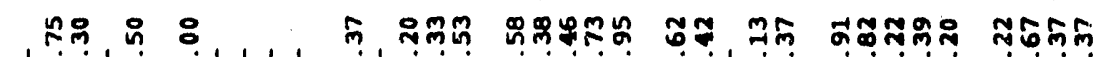

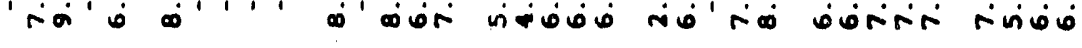

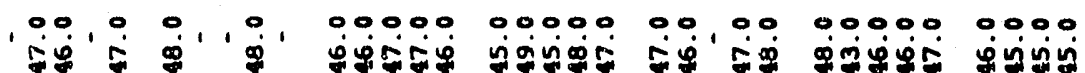

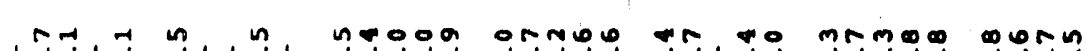

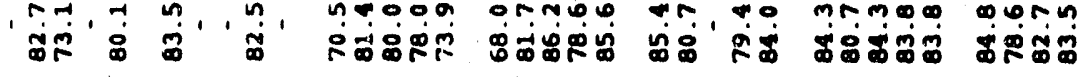

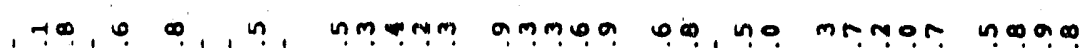
मूं

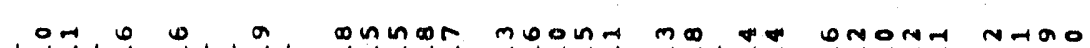

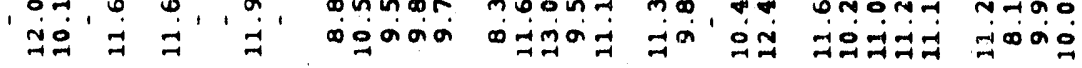

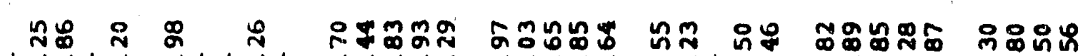
'ơn'

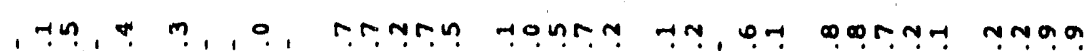

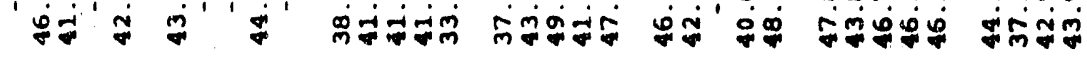

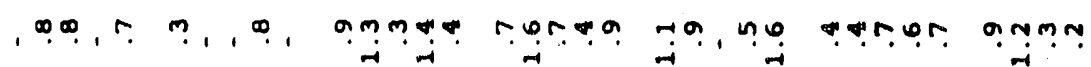
, mn, m, ए.,

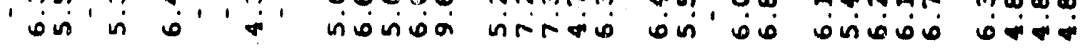

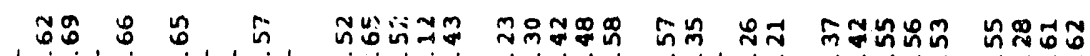
现)

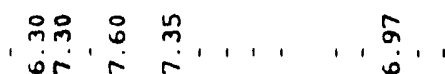
$, 00,0,0,0,0,0000$

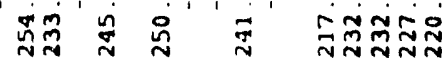
$00000000,1,00,00$

0000000,00000000000

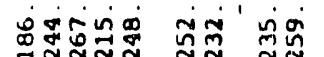

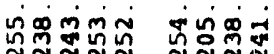

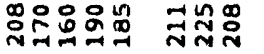
ํํㄱำ , 이, , , 이, 000000000

00000 io ogoing fogmo

monoun oining

융유

영

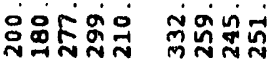

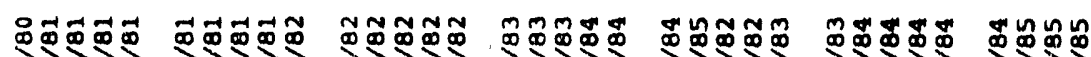

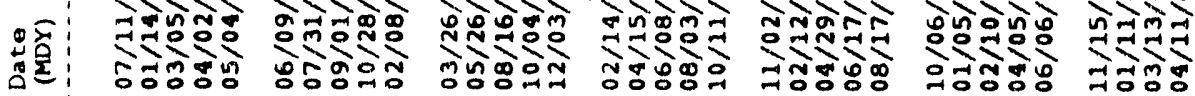

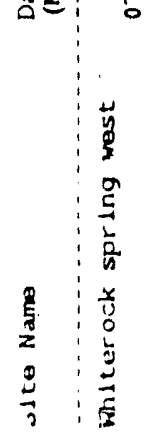




\section{APPENDIX D}

TIME-SERIES ISOTOPE DATA FROM SELECTED SPRINGS ON THE NTS 
Stable isotopes of hydrogen, oxygen, and carbon are presented in delta ( $\delta$ ) notation as a permil $(\%)$ variation from SMOW (Standard Mean Ocean Water) and PDB (PeDee formation belemnites), respectively. 


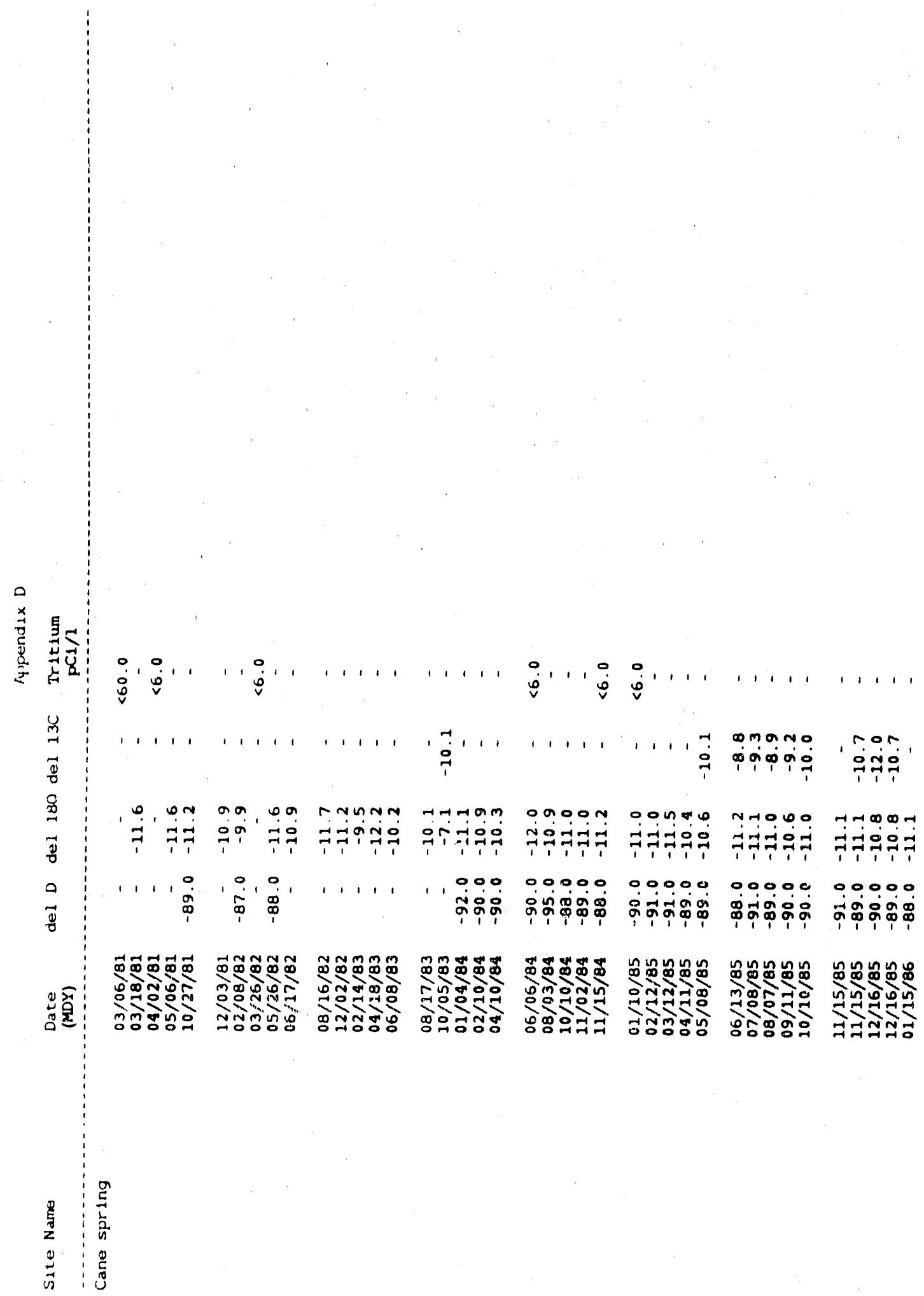




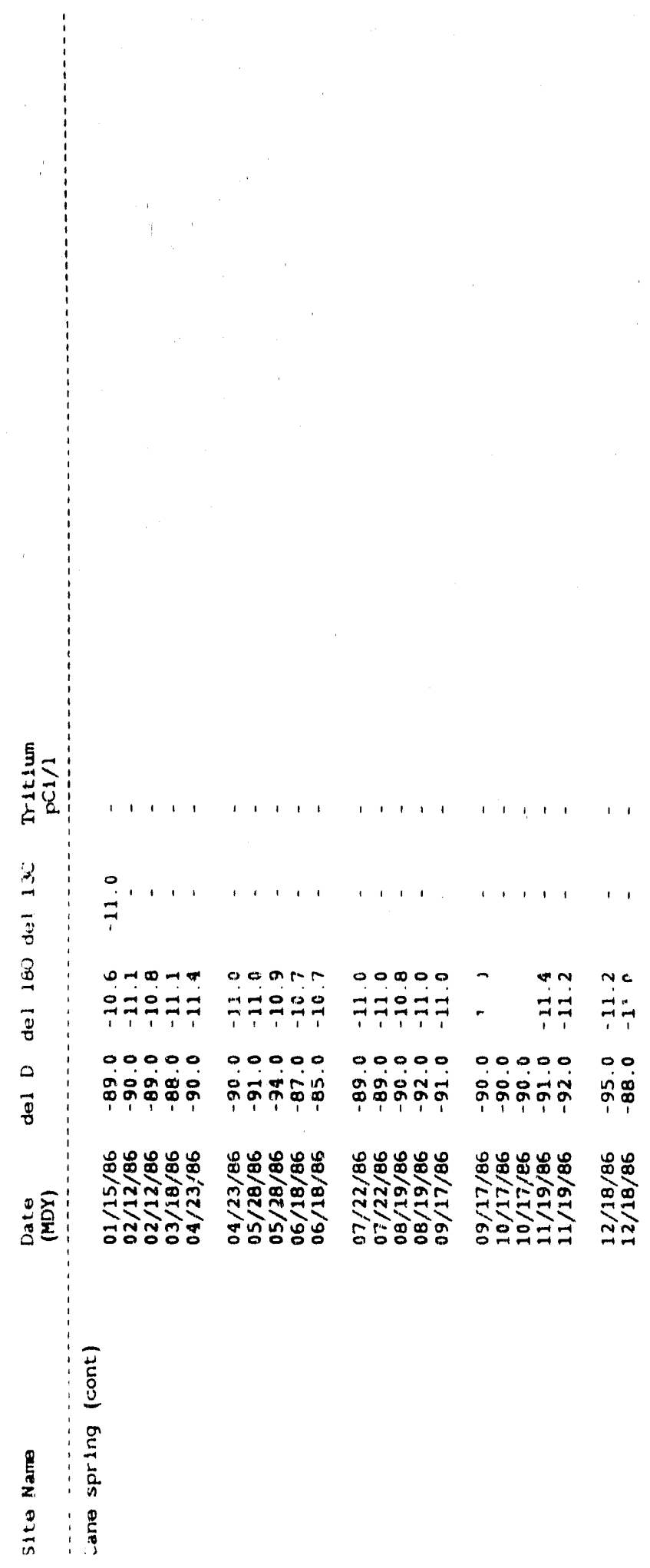




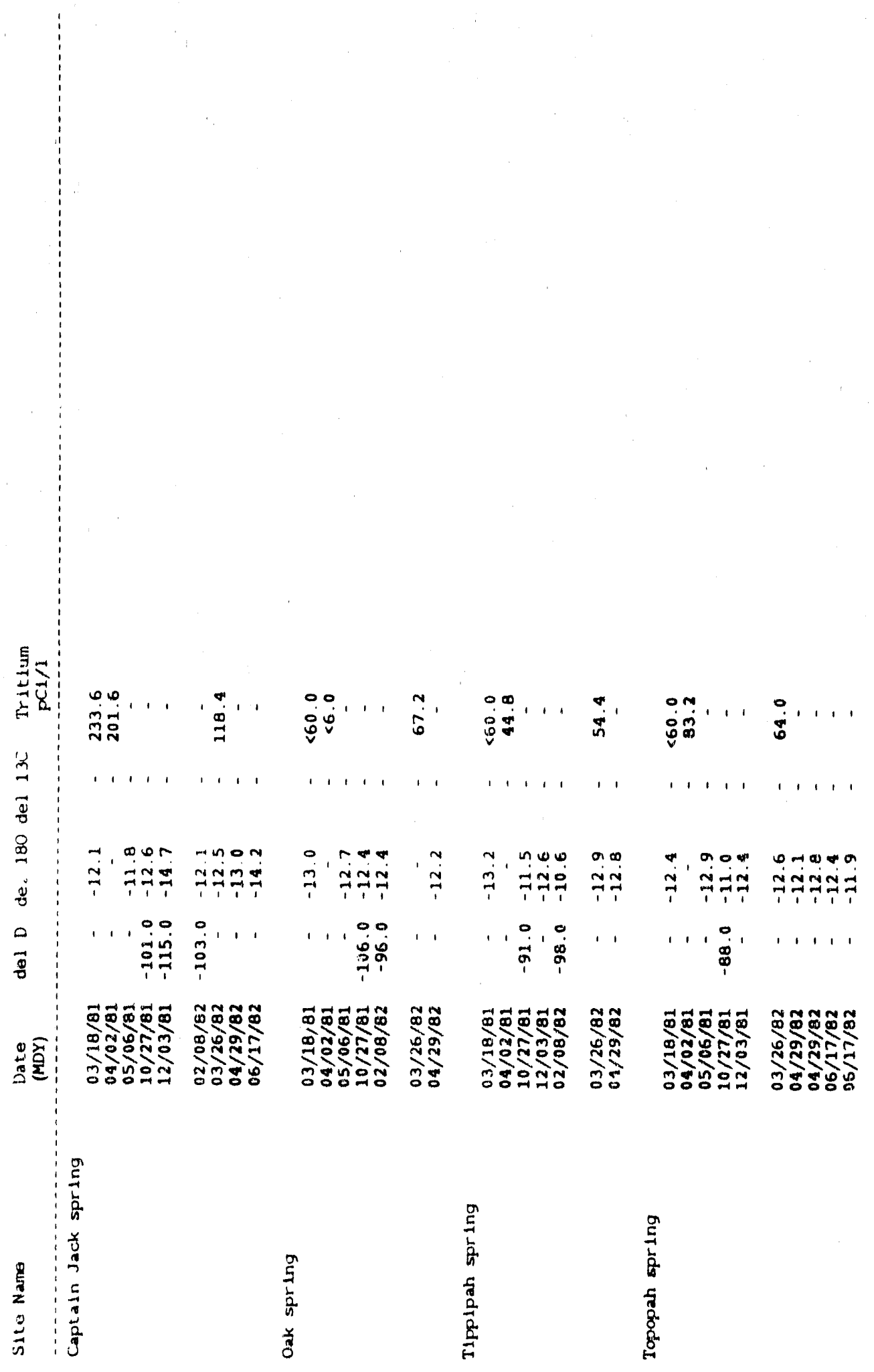




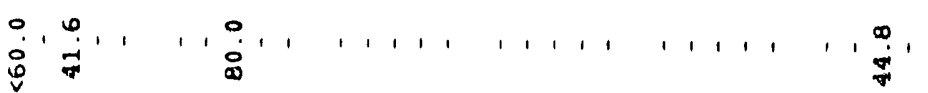

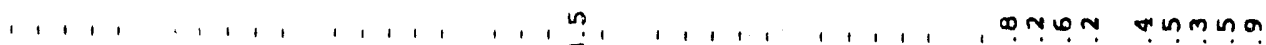

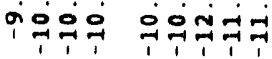

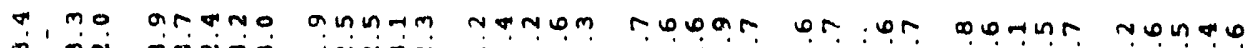

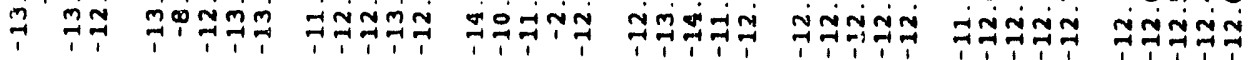

$1,1,000,10,1,1,1,00000000000000000000$

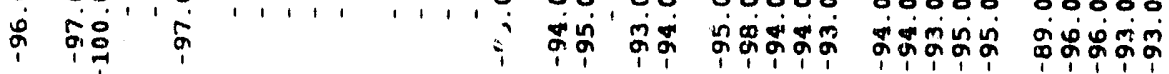

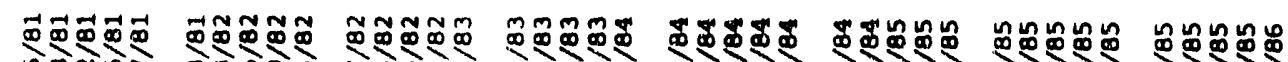

资

苟

뭄

亮

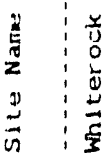




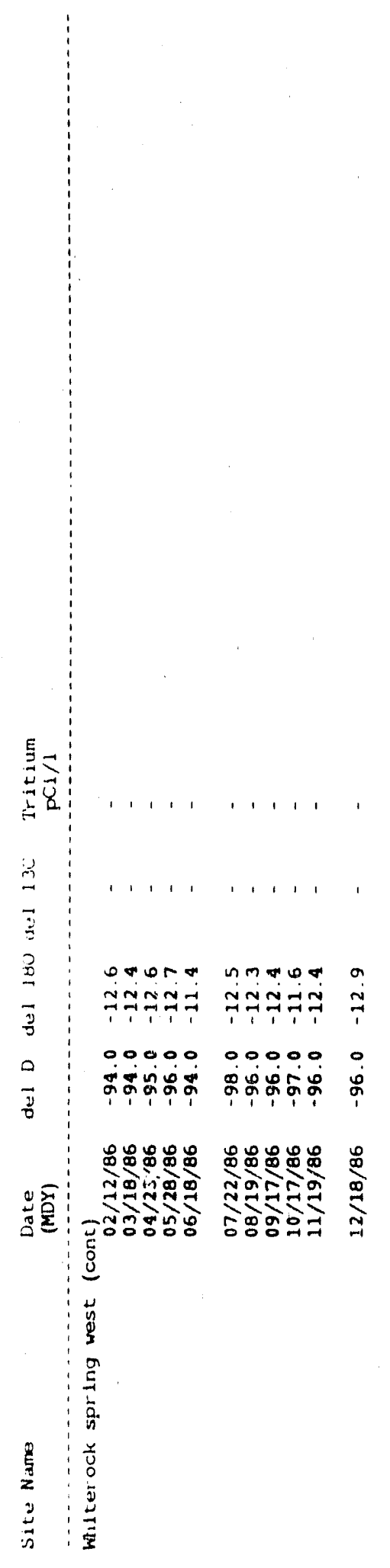


APPENDIX E

COMPUTER OUTPUT RESULTS FROM SNORM 

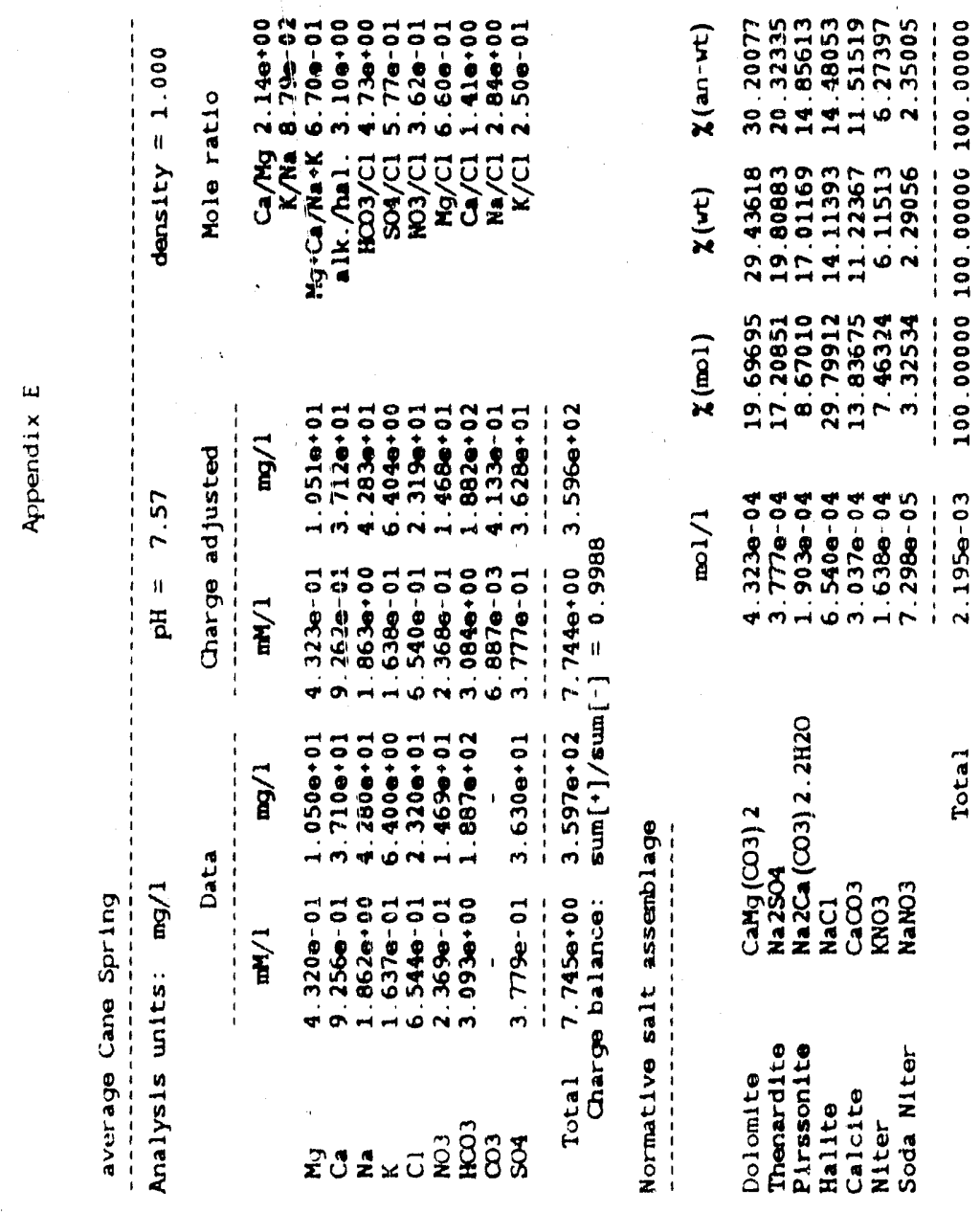

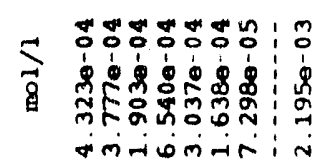

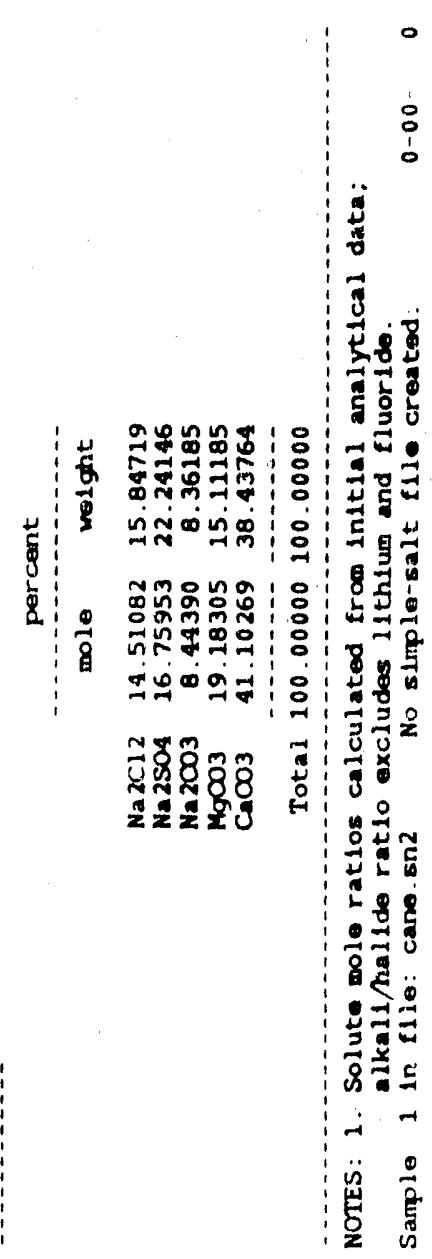




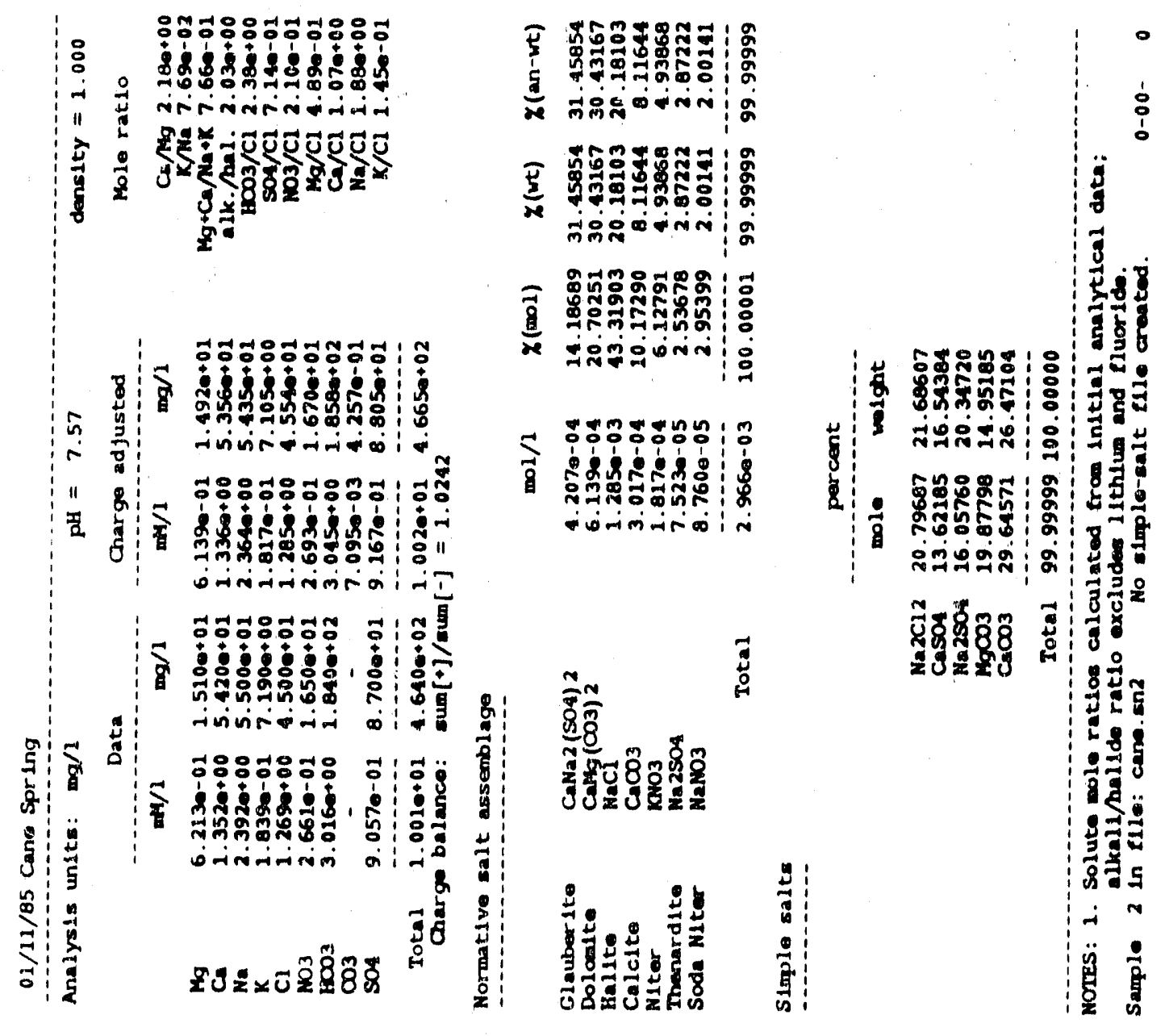




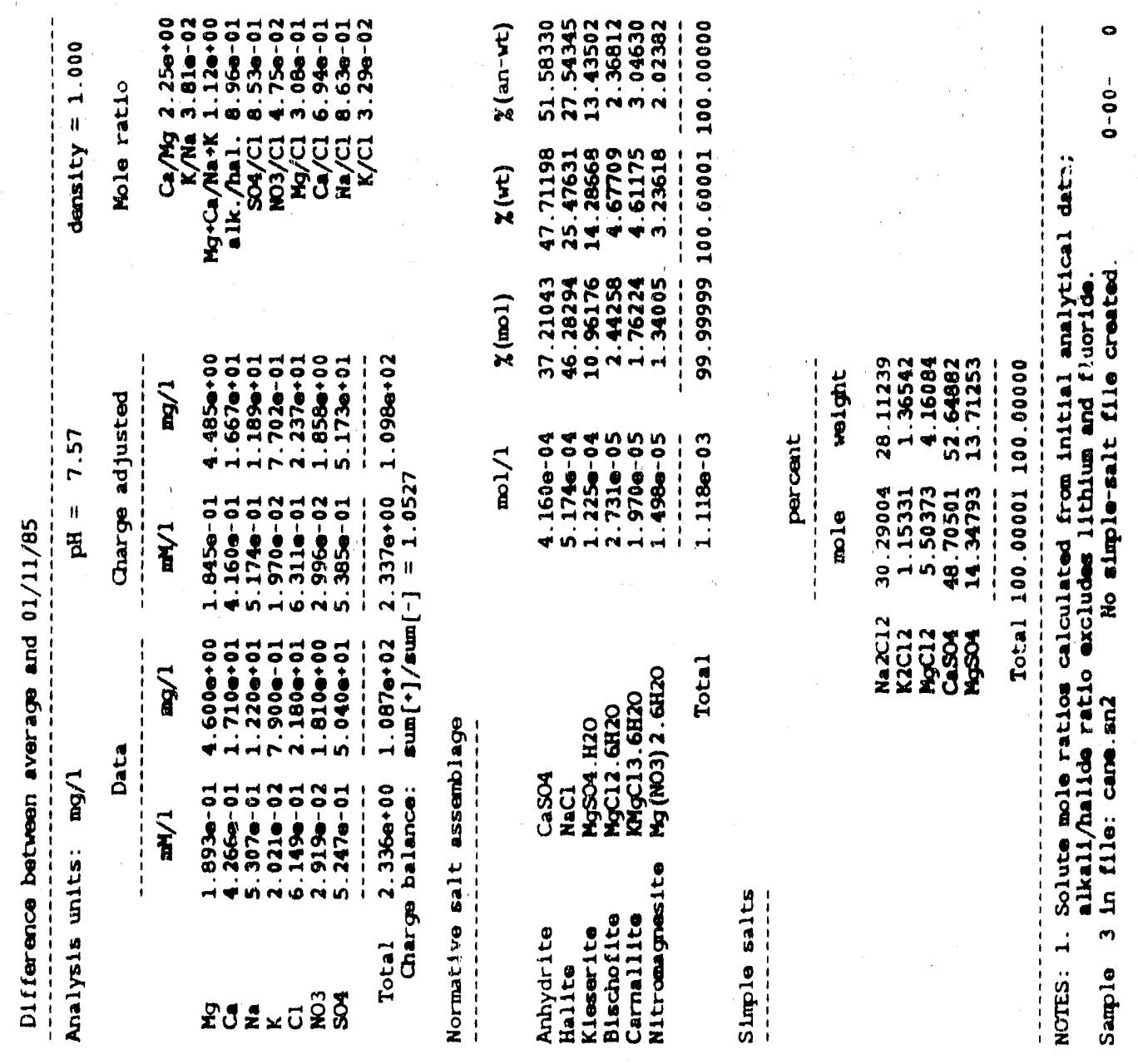




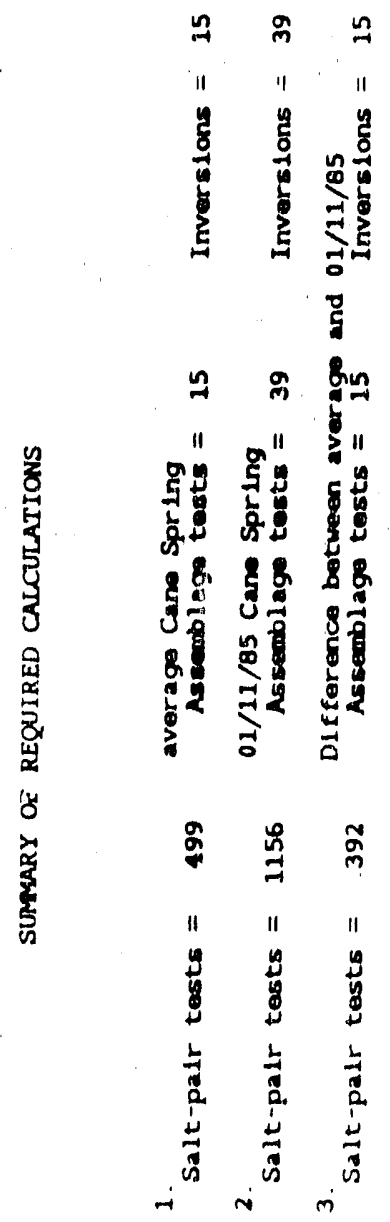




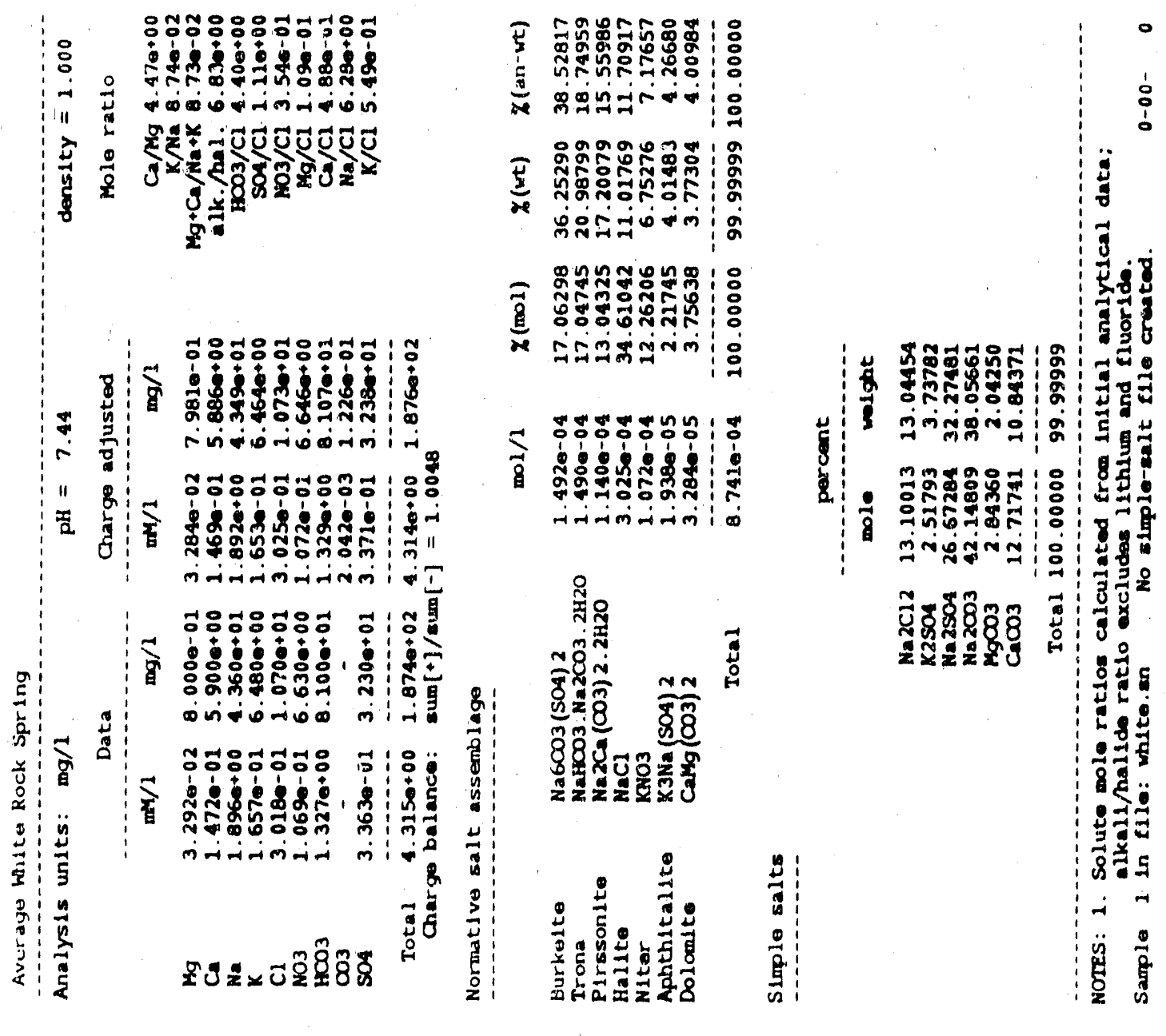



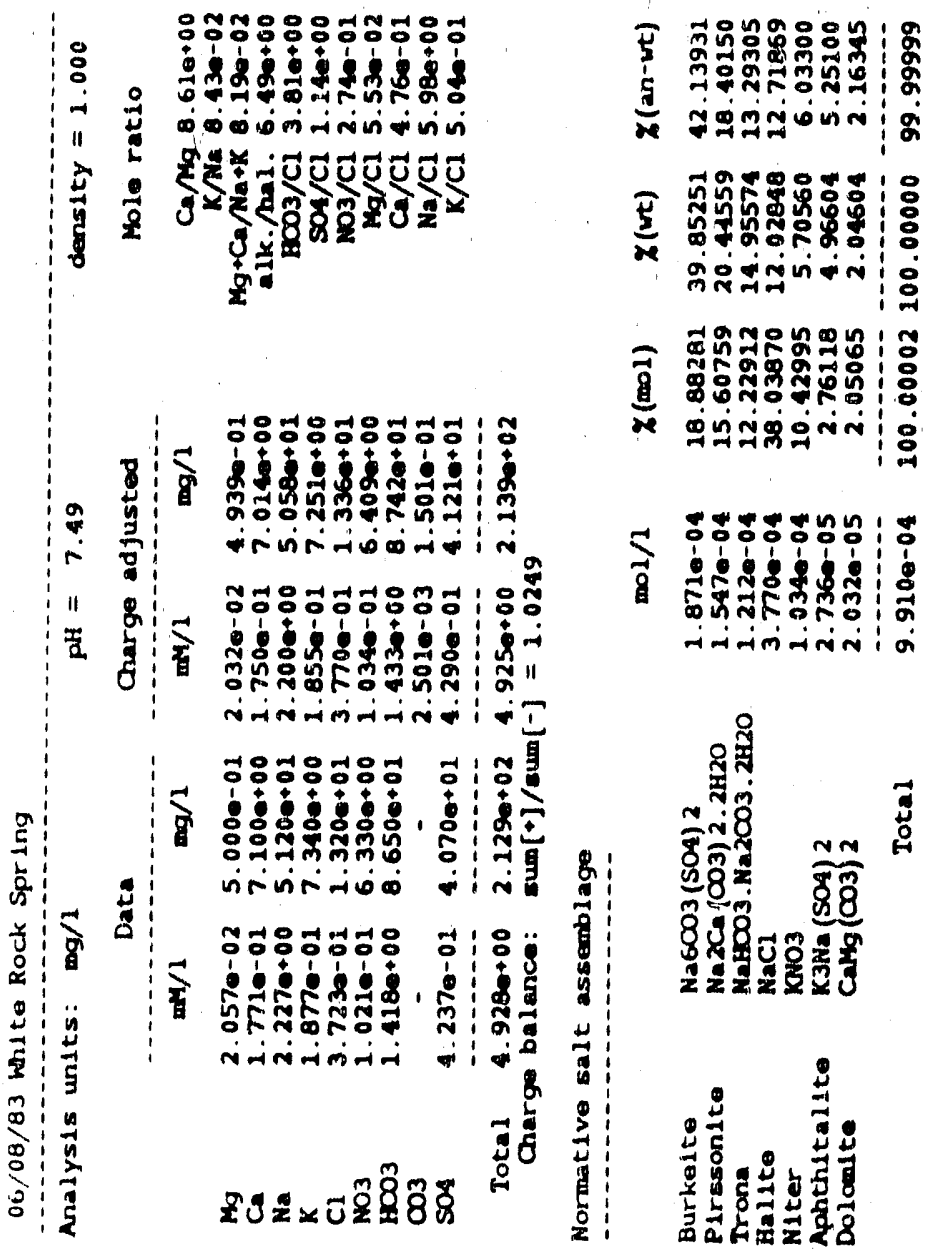

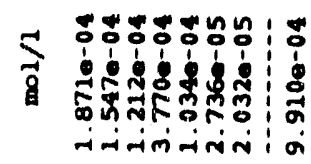
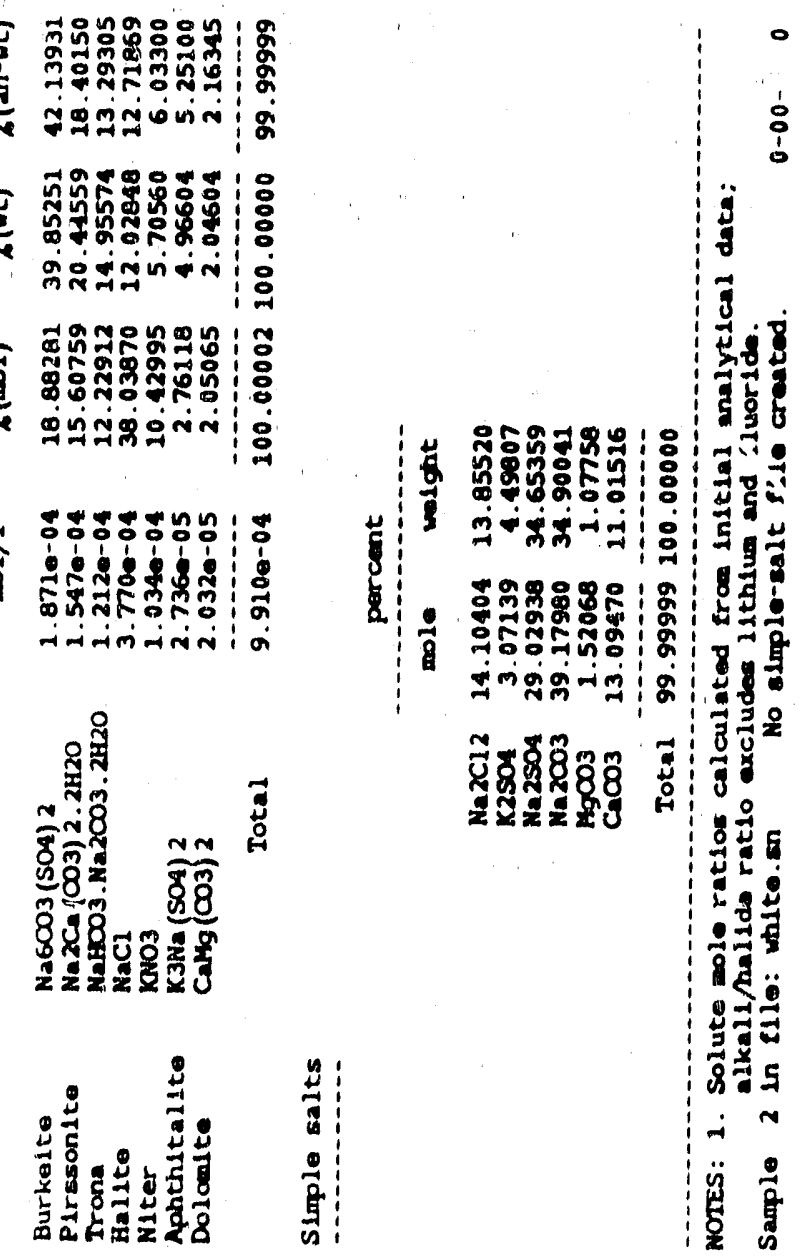


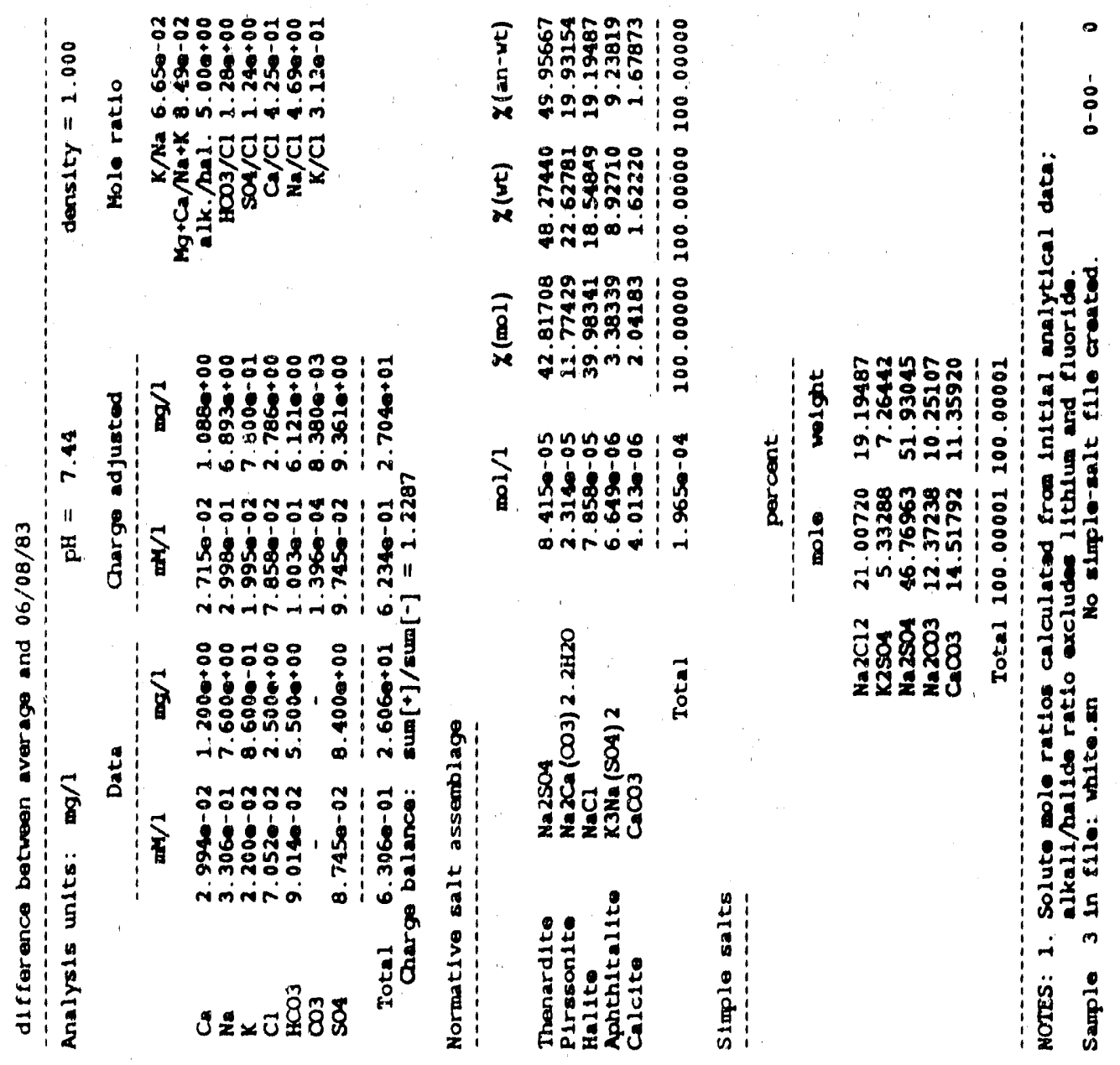



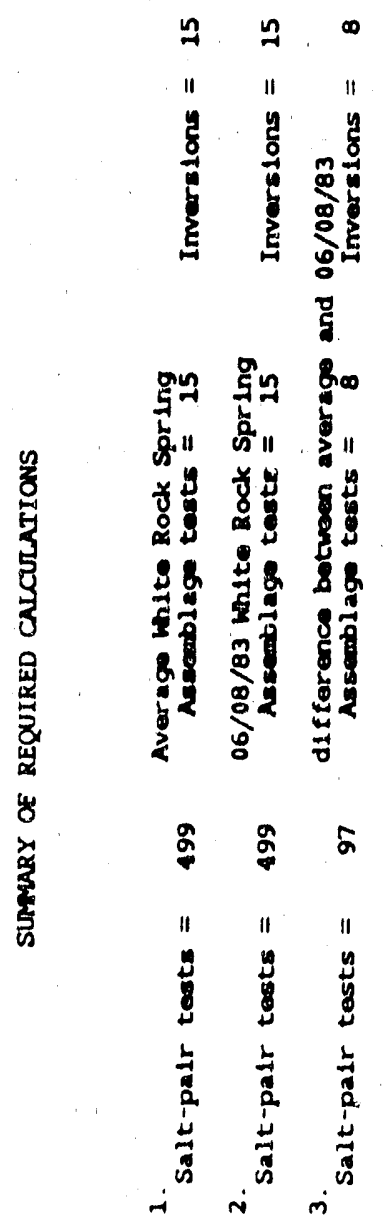


\section{APPENDIX F}

MONTHLY SUMMARY STATISTICS OF MICROLOGGER DATA FROM CANE AND WHITEROCK SPRINGS 
Summary files are listed and include all available parameters measured during each month. The data file name corresponds to the year and month the data was, for example:

Data File: 85.11.data

Contains data from November 1985

The summary statistics are computed over the entire month and consist of minimum (Mir) ), maximum (Max.), mean, standard deviation (SDEV), summation (Sum), range, and number of measurements (No.). Also included are the number of days during the monthly period of record. Raw data are available on magnetic tape upon request. 

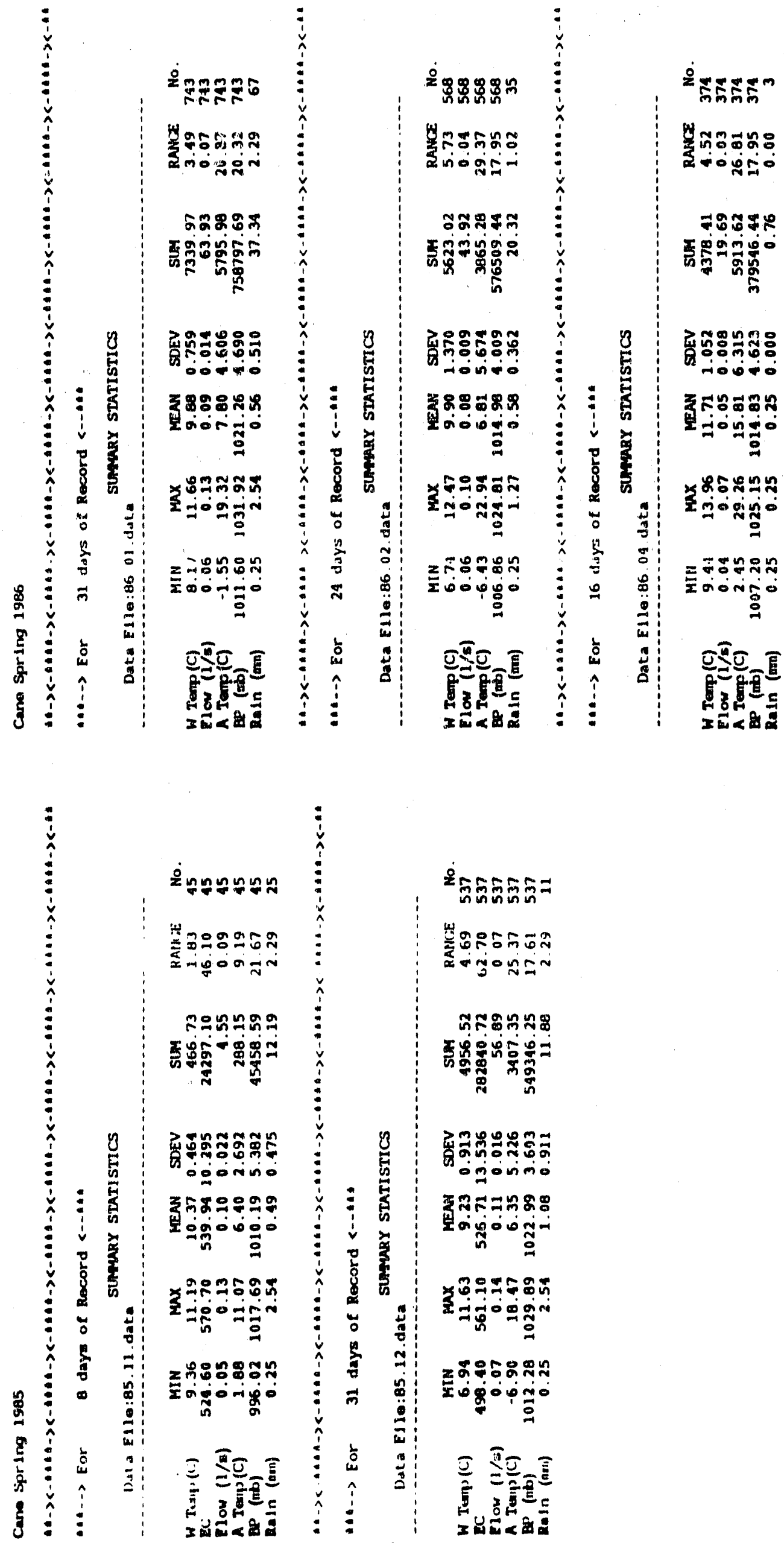

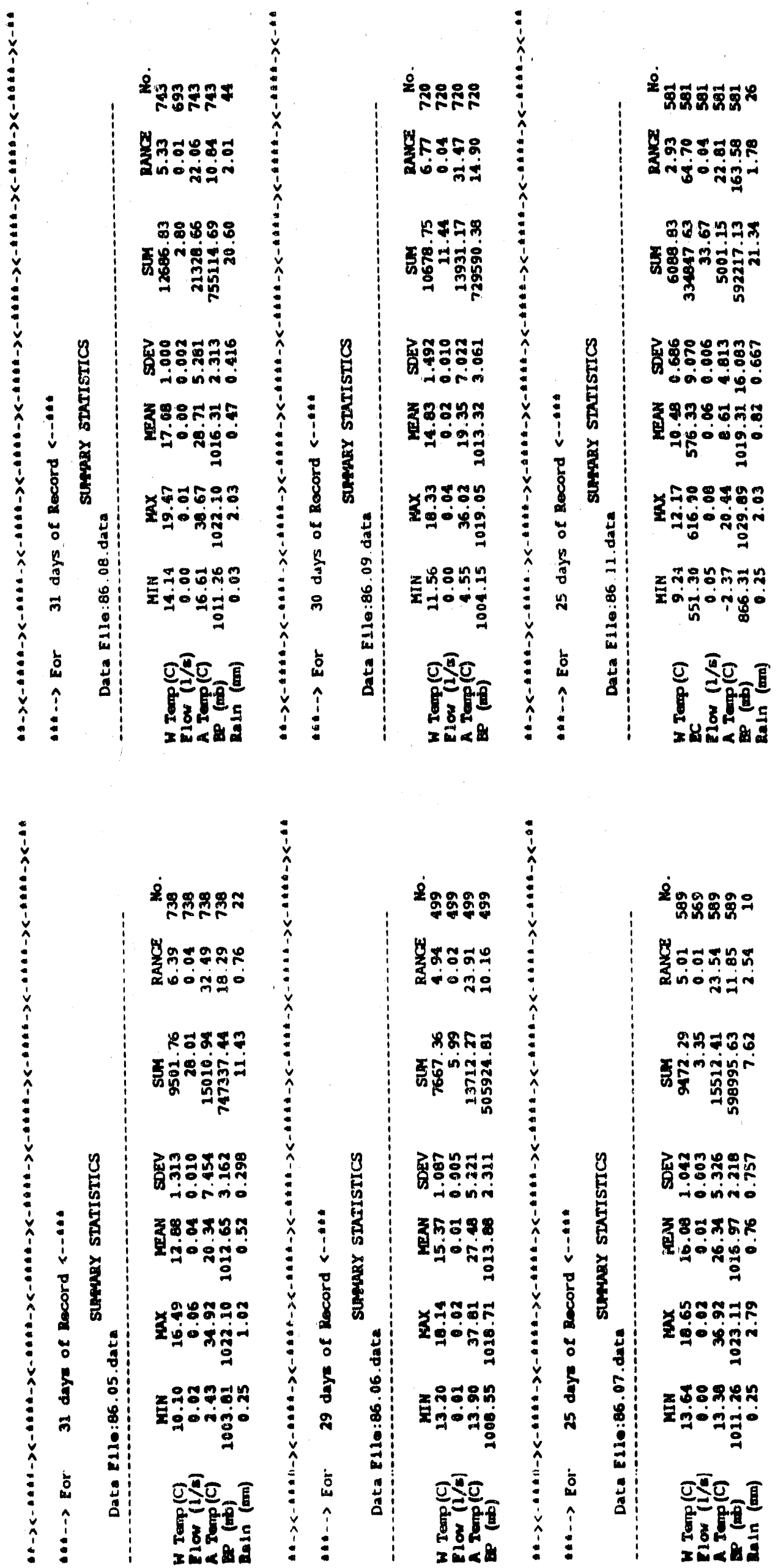

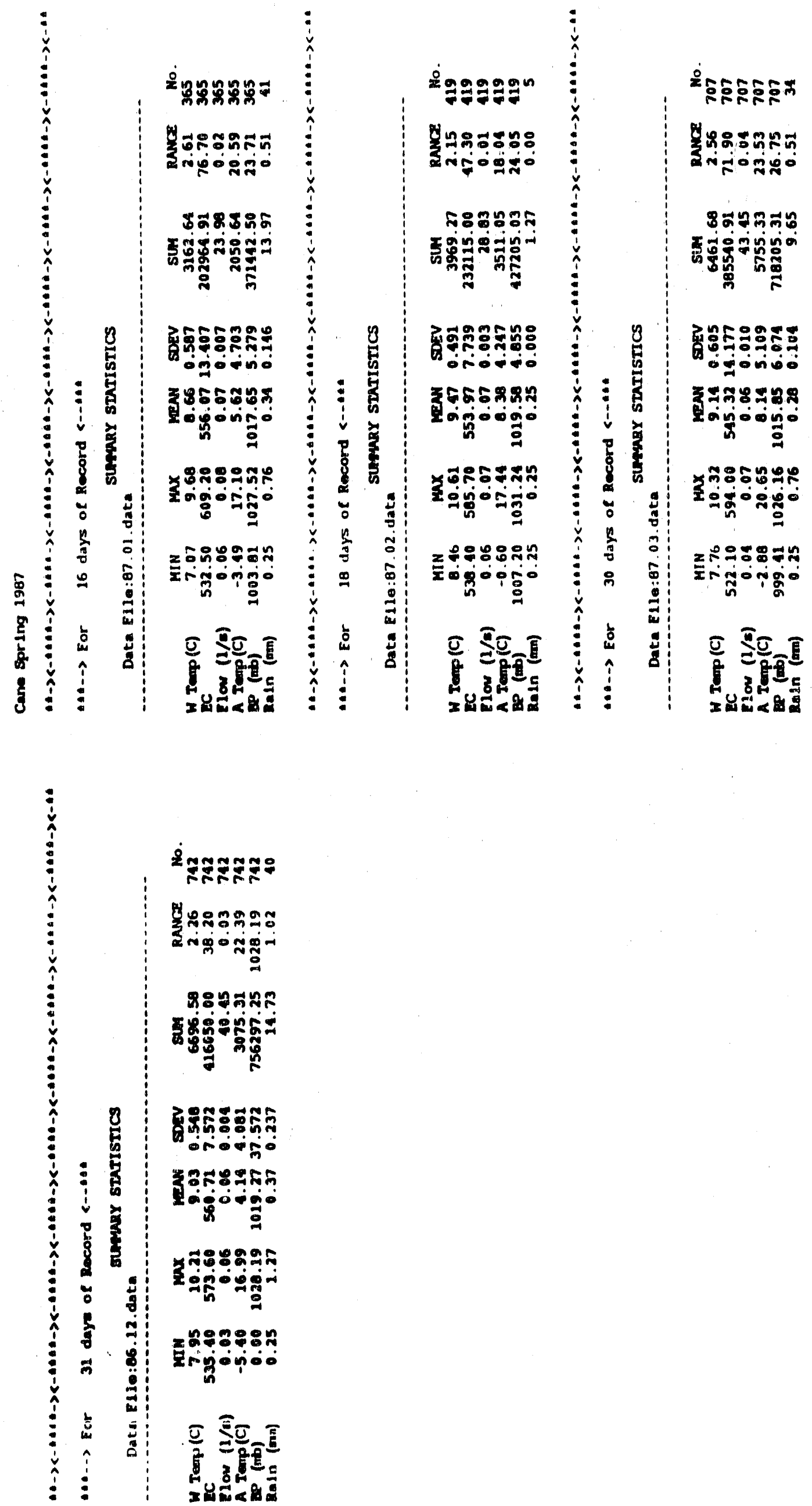

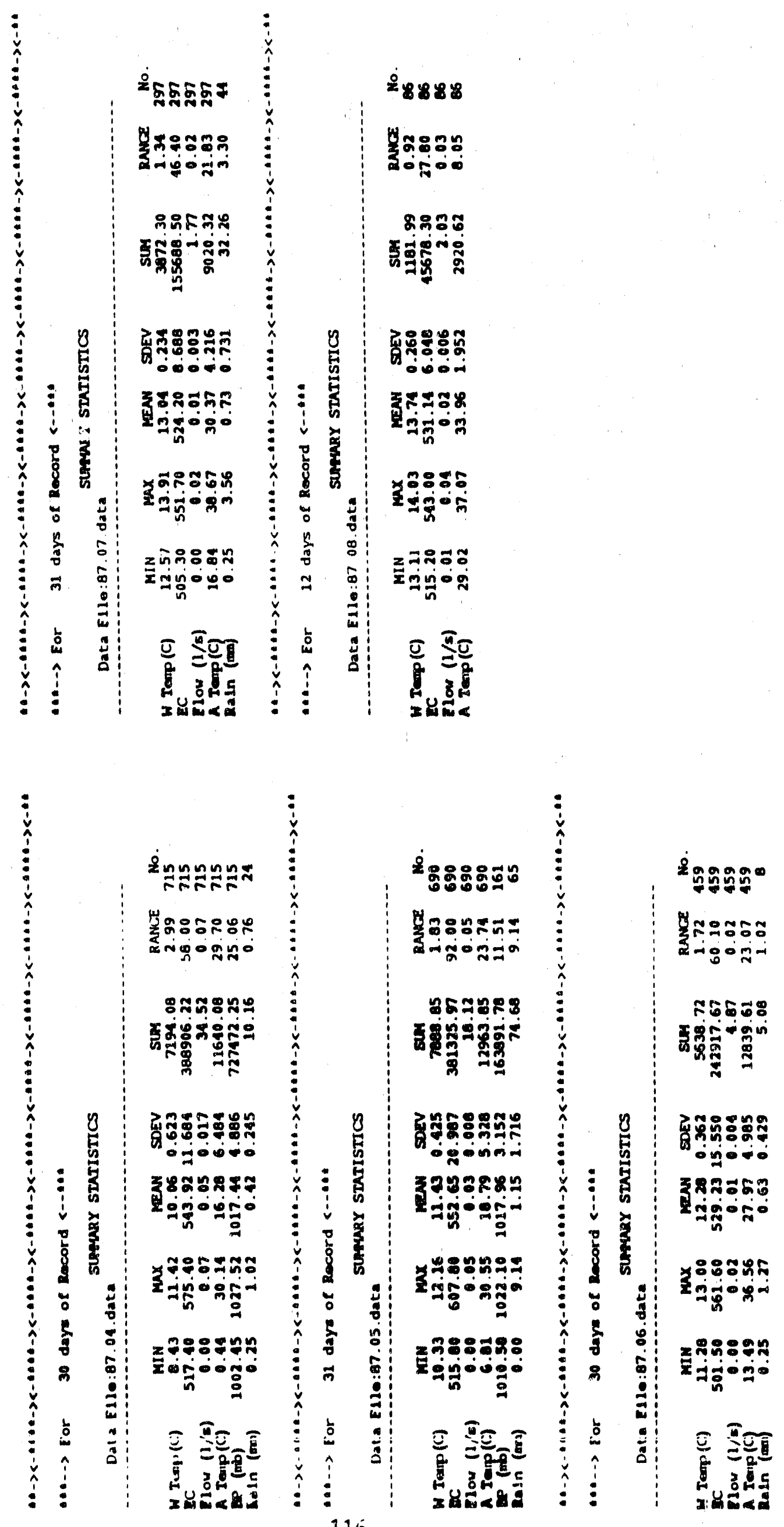


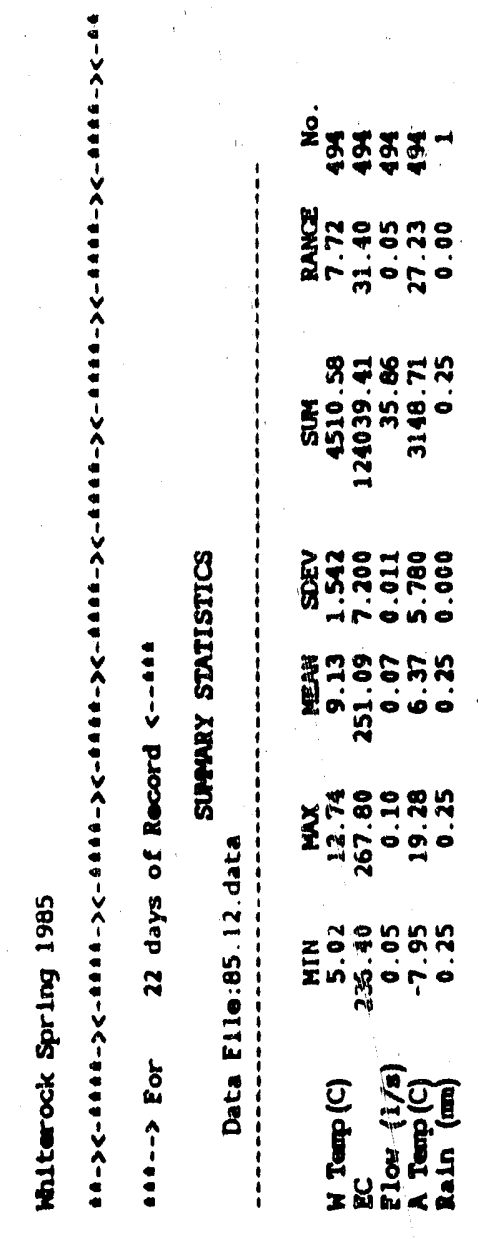



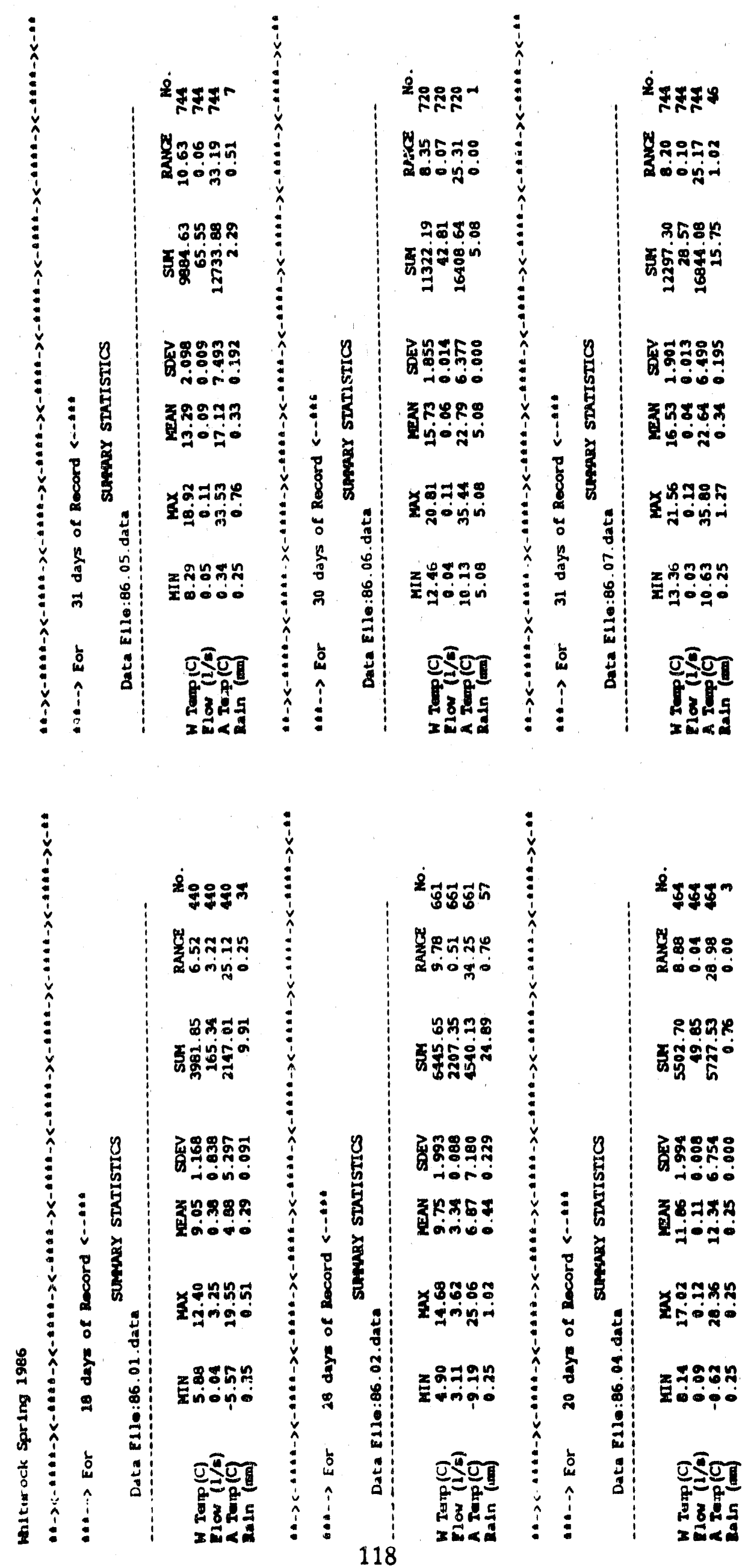

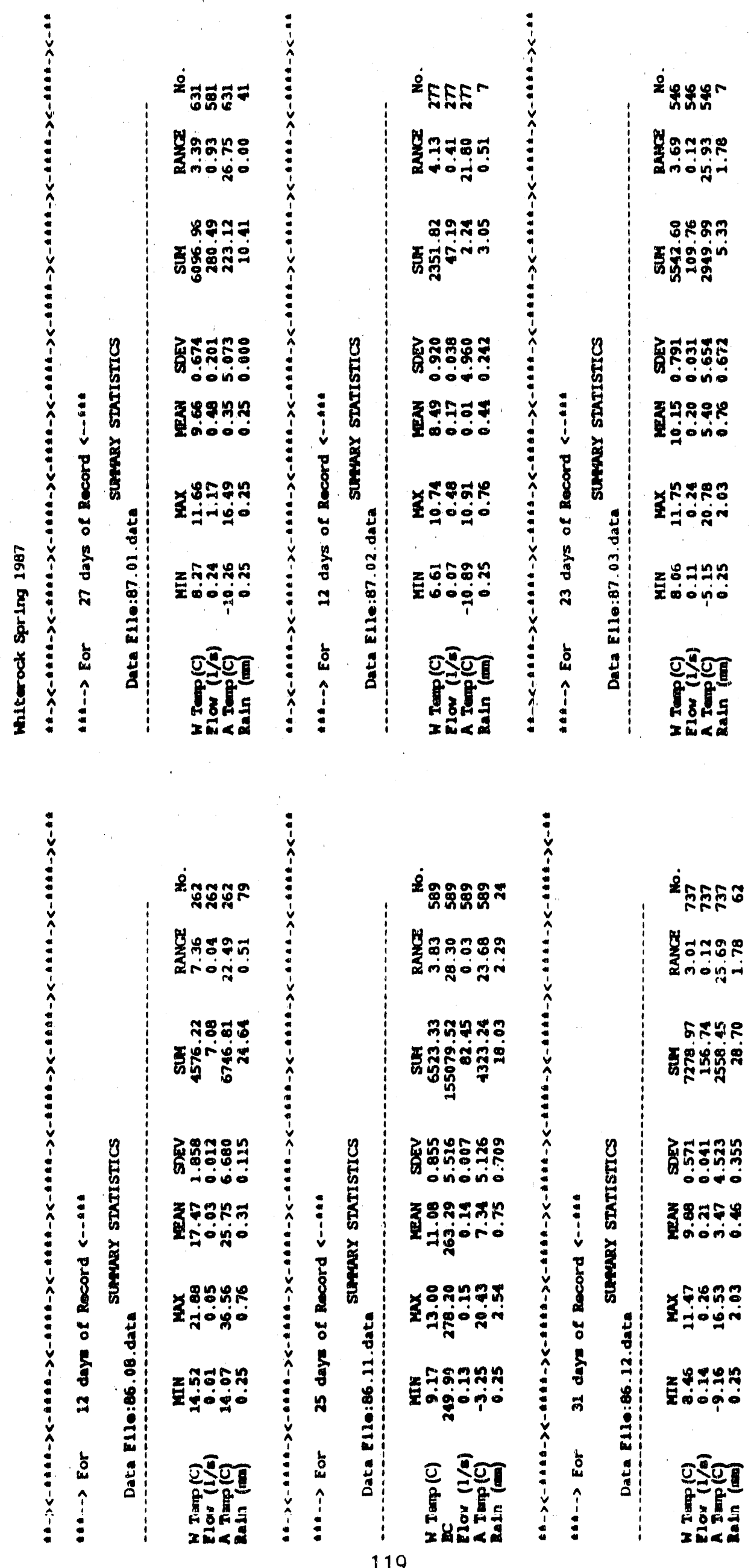

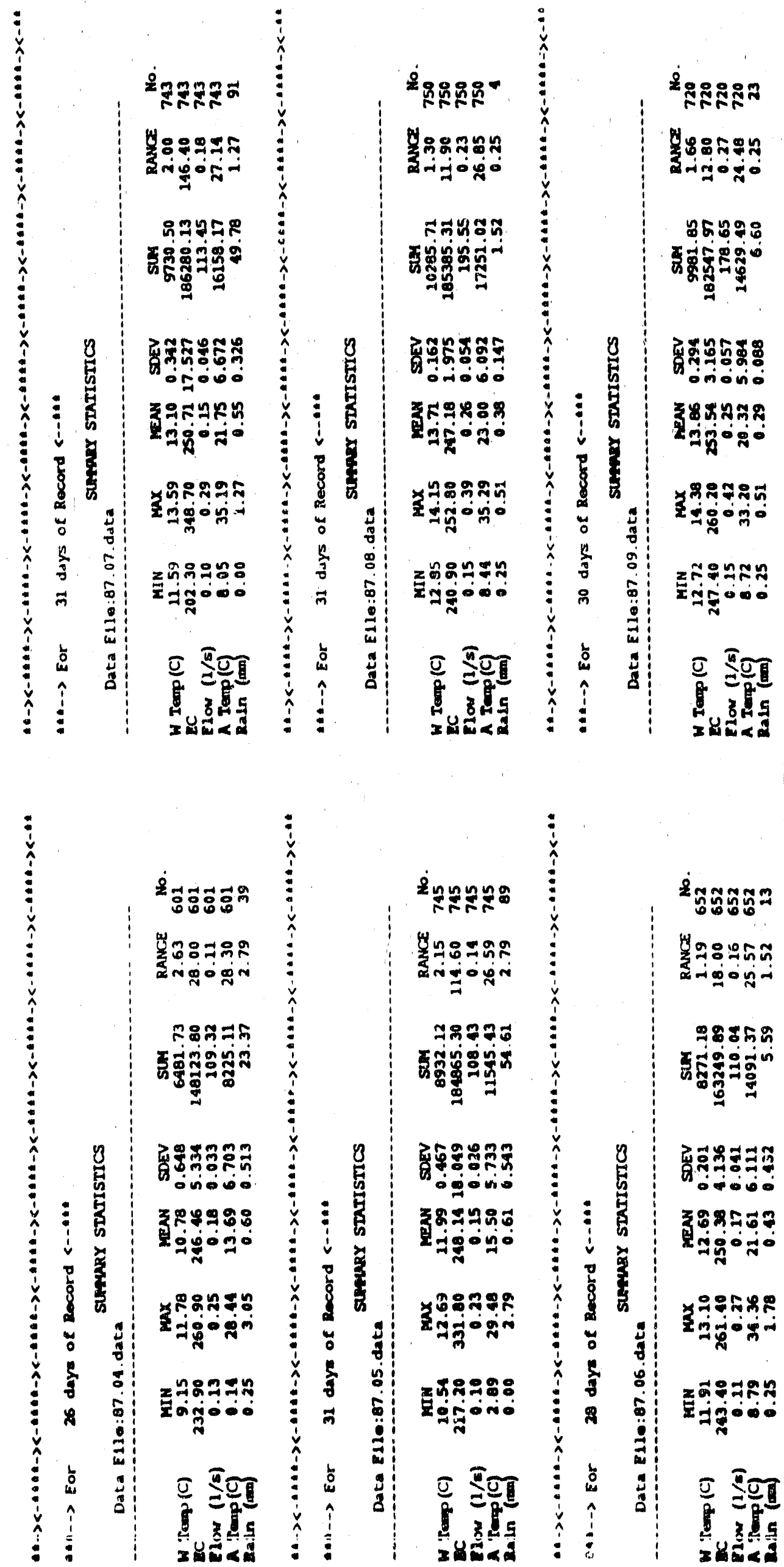

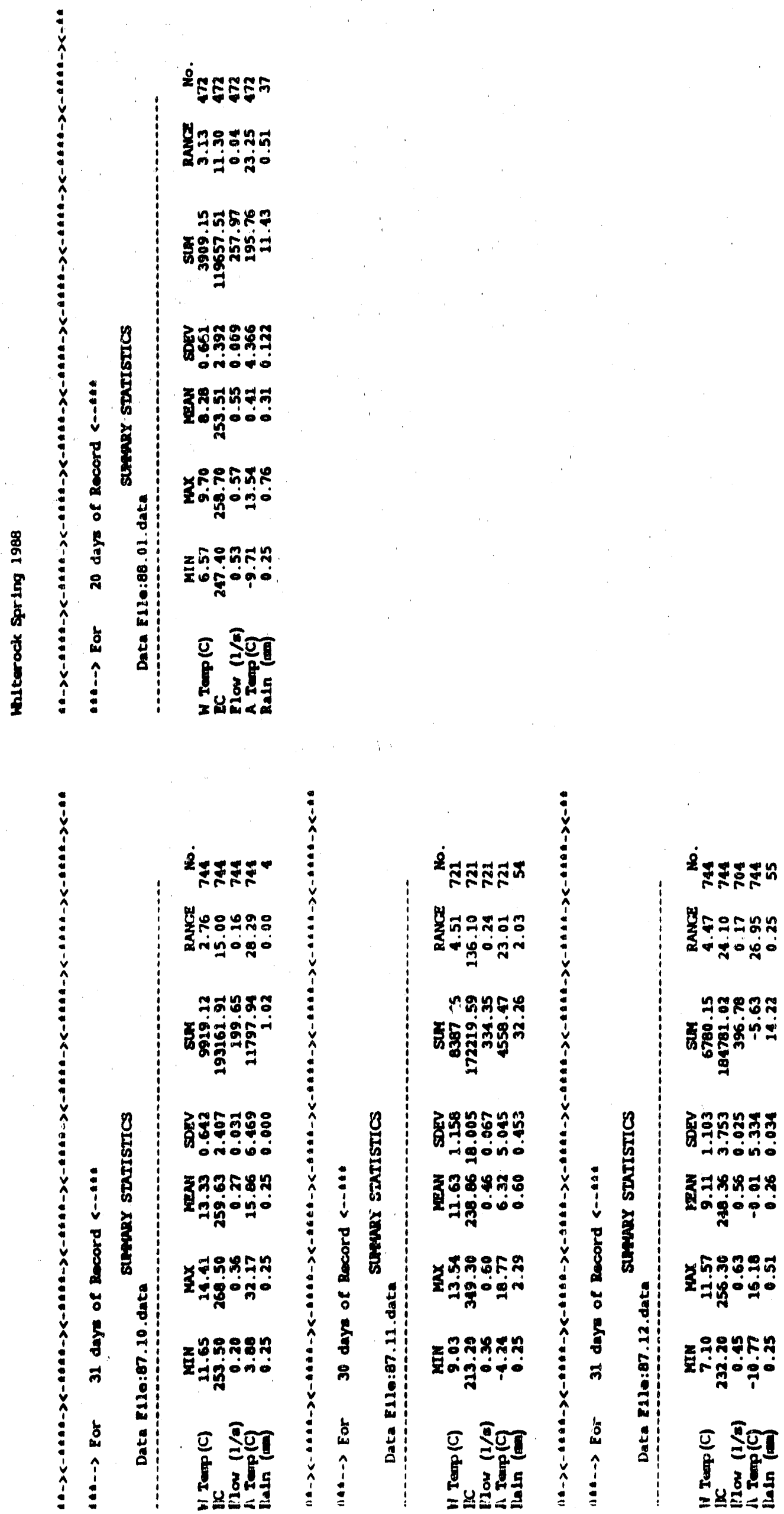

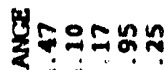

इं०ूं०

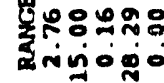

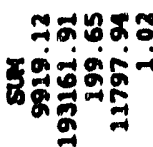

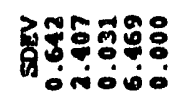

388582

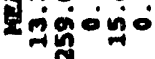

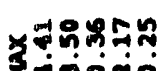

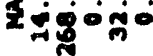

ชุำร8

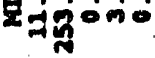

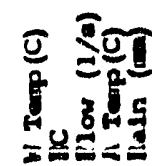

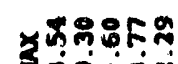

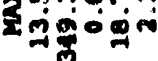

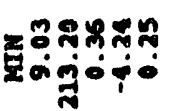

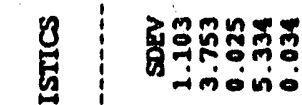

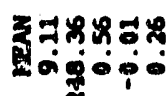

วกำ

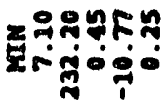

पू 

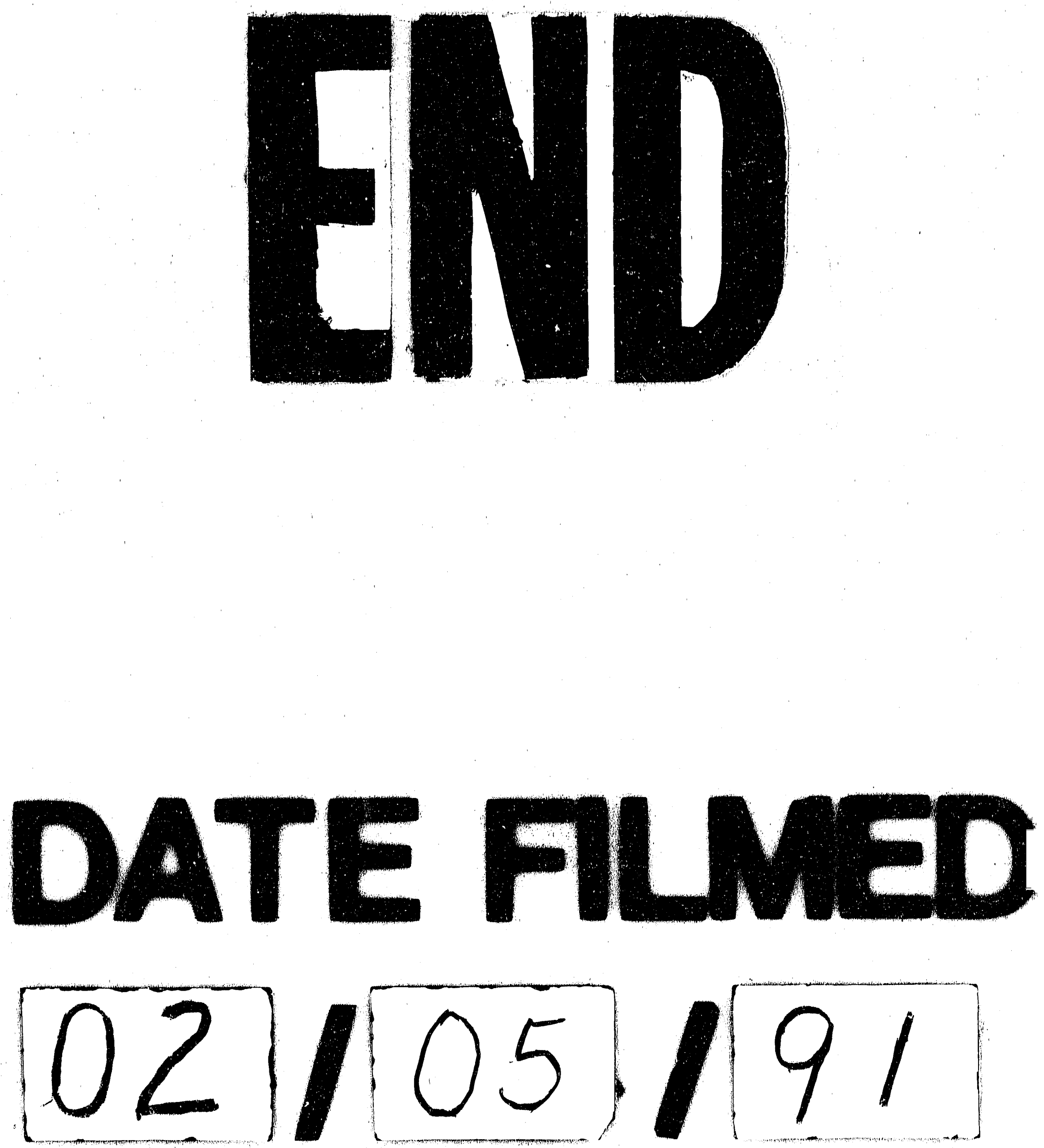
